\title{
Agricultural Policy Support, Production Incentives and Market Distortions in Sub Saharan Africa
}

\author{
Dissertation \\ to obtain the Ph.D. degree \\ in the International Ph. D. program for Agricultural sciences in \\ Göttingen (IPAG) \\ at the faculty of Agricultural Sciences, \\ Georg-August- University Göttingen, Germany \\ presented by \\ Jean Balié \\ born in Santafé de Bogota, Colombia
}

Gottingen, March 2016 
D7

1. Name of supervisor: Professor Doctor Stephan von Cramon Taubadel

2. Name of co-supervisor: Professor Doctor Bernhard Brümmer

Date of dissertation: 14 July, 2016 
To my children

"Realize deeply that the present moment is all you ever have" Eckhart Tolle 


\section{Summary}

Most countries in the world adopt policies in support of their agricultural sectors. In doing so, governments seek to influence farmers' behaviour through various channels. While these policies and their incidence have long been monitored for member countries of the Organization for Economic Cooperation and Development (OECD), there is scarce literature on those provided by the developing countries and especially in Sub Saharan Africa (SSA). Yet, the food and agricultural policies adopted by governments in Sub Saharan Africa (SSA) since their respective independences have gone through a number of phases characterized by changing objectives, intensities of state intervention in the economy, levels of protection or taxation in agriculture, and amounts of public spending and aid to agriculture. There has not been any systematic tracking of these changes and their implications for agricultural development and rural transformation, poverty eradication and food security, for example.

In this respect, the work by Kym Anderson as part of the World Bank's research project on Distortion to Agricultural Incentives constituted a major breakthrough. FAO's Monitoring and Analysing Food and Agricultural Policies (MAFAP) programme followed this path with the objective of establishing countryowned and sustainable systems to monitor, analyse, and reform food and agricultural policies to enable more effective, efficient and inclusive policy frameworks in support of agricultural development in a growing number of developing and emerging economies. Most of the research underpinning this dissertation builds on MAFAP data and analyses. The dissertation focuses on policy interventions essentially in the form of market price support or budgetary transfers, and their combined incidence on market price signal transmission, agricultural production incentives and the resulting supply response.

Results presented in chapter 2 show that policies adopted by governments, for example, in response to price shocks in international markets altered the transmission of international price signals to farmers in developing countries. We also find that other factors play a role in this inadequate price transmission such as transport costs and changes in exchange rates. Moreover, it also appears that price changes in any particular country are not necessarily due to changes in world market prices, which suggests that domestic market conditions, largely determined by the policy environment, play an essential role. Finally, we also find that price movements in Africa exhibit different patterns than those in other regions, with higher levels of price variability for maize and rice mostly due to the domestic market conditions.

Taking the case of rice and cotton which are two key commodities for several SSA countries, chapter 3 shows that observed market distortions reflect the combined effects of market and policy failures. In the case of rice, these prevent border protection from reaching farmers while raising consumer prices. Cotton ginning and marketing is concentrated in a small number of private sector companies in most countries studied. Farm level nominal rates of protection (NRPs) provide evidence of market failures in these countries that may be mitigated by policies that set indicative prices and encourage competition. Interestingly, the NRPs point at non-market failures in the two countries that maintain parastatal monopsonies for cotton.

Chapter 4 focuses on inputs subsidies which are found to be a widespread option of public support to agricultural production in SSA. Input subsidies have received close to $35 \%$ of agricultural-specific spending on average. These expenditures have tended to get stuck into agricultural budgets over time, and exhibit sub-optimal execution rates. Input subsidies are primarily funded by national taxpayer money while 
donors tend to invest more on public goods. These findings confirm that input subsidies tend to crowd out other spending categories likely more supportive of long-term agricultural development objectives.

The effects of market price signals and policy interventions on the supply response of farmers in SSA are investigated in chapter 5 . Results show that farmers in SSA are actually able to respond to higher prices with increased production even if with a limited intensity. Moreover, results show that direct price incentives arising from border protection and government intervention in domestic markets and price shocks at the border also influence farmers' decisions and are more important than macroeconomic policies. Moreover, omitting marketing costs from the supply response function leads to an underestimation of the price elasticity. Conversely, using wholesale instead of farm gate prices as proxy for producer prices leads to an overestimation of the price elasticity of supply. 


\section{Acknowledgements}

I would like to thank those who inspired and assisted me to get through the process of bringing my doctoral project to completion.

First of all, I would like to thank Prof. Dr. Stephan von Cramon-Taubadel who trusted me and gave me the opportunity to complete my PhD while working at FAO. Doing my research under his supervision, I have learned a lot more about what thinking as an economist really means and entails. Moreover, through his lectures and also taking his papers as examples, he also helped me immensely to become more effective at writing scientific papers.

I also thank Prof. Dr. Bernhard Brümmer for accepting to be my second supervisor. I learned a lot from him during the period we coincided in the Ulysses project, especially on complex time series analysis.

I am also indebted to Prof. Dr. Hartwig de Haen. He was serving as Assistant Director General in FAO when I joined the Economic and Social Department of this organization and I recall that we had stimulating discussions on how to make our policy assistance to member countries more effective. What is more, we worked together quite intensively on the scoping phase of the Monitoring and Analysing Food and Agricultural Policies (MAFAP) project until it was approved in 2009. Hartwig has been instrumental in determining the fate of the MAFAP project and inspirational in establishing the guiding principles that would be used throughout. I am glad he accepted to be part of the panel as most of this dissertation builds upon MAFAP results and data.

My empirical analysis would not have been possible without the financial support of the Bill and Melinda Gates Foundation (BMGF) for the last seven years. I thank my successive direct interlocutors at the BMGF, Prabhu Pingali, Ellen Mc Cullough, Mumukshu Patel, and Alan Rennison for their permanent and unconditional support to the work of MAFAP.

I am also thankful to many FAO colleagues for the very rich professional interactions we have had for so many years. Christian Derlagen, Pascal Lemasle, Emiliano Magrini, Cristian Morales Opazo, and Signe Nelgen have been my closest collaborators in the last few years. I have particularly enjoyed every single moment with each one of them.

My most sincere thanks also go to Jesus Barreiro-Hurlé, David Dawe, Léopold Ghins, Emiliano Magrini, Alban Mas Aparisi, Cristian Morales Opazo, Guillaume Pierre, and Cameron Short who were my co-authors for the papers included in this dissertation.

I would also like to acknowledge previous colleagues and supervisors who mentored me during my professional career at FAO including Materne Maetz, Mafa E. Chipeta, and Keith Wiebe. I am particularly grateful to Keith as, in addition to being a friend, he encouraged me to pursue my PhD.

Above all, I want to thank Brigitte, my wonderful wife, and Elise, Louis, Nina and Francesco, our extraordinary children, for their support and patience but also for their capacity to express their love every day. Thank you very much for helping me to grow as a husband, a father and a better person.

Gottingen, May 2016

Jean Balié 


\section{Table of contents}

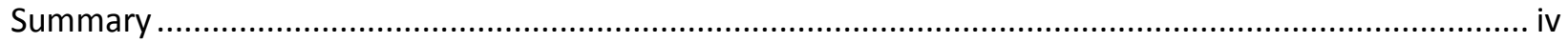

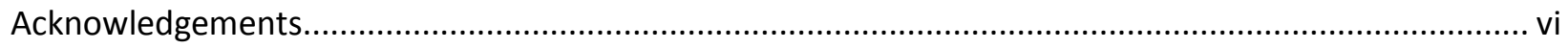

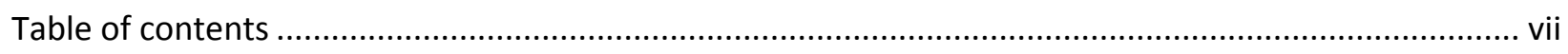

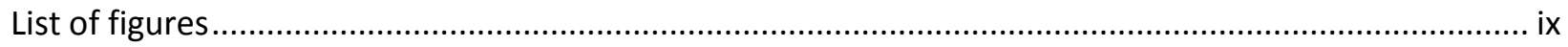

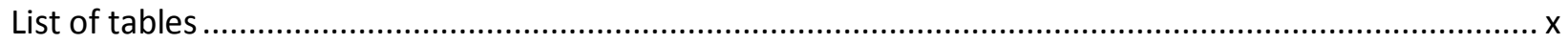

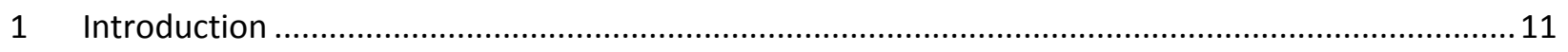

1.1 Motivations behind the research ........................................................................................... 11

1.2 Objectives and research topics of the study ........................................................................ 13

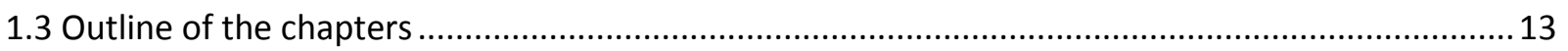

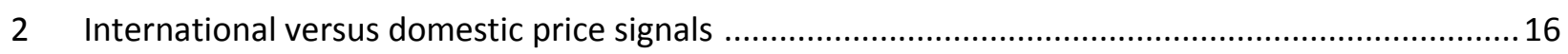

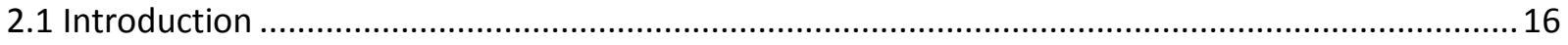

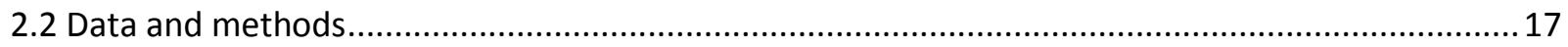

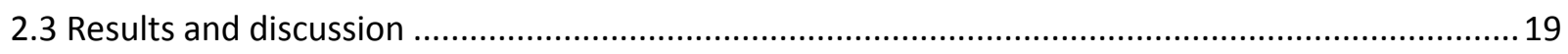

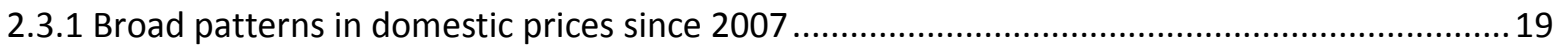

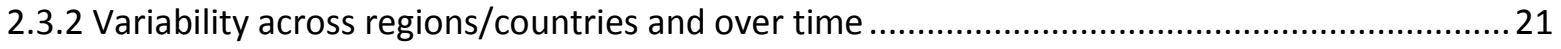

2.3.3 Price movements on domestic and world markets ..........................................................26

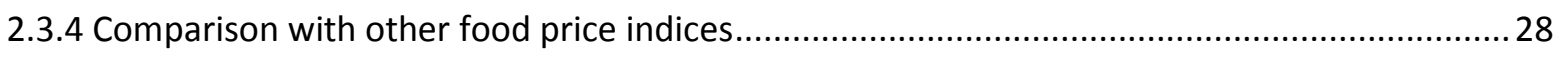

2.4. Summary and conclusion ..................................................................................................... 30

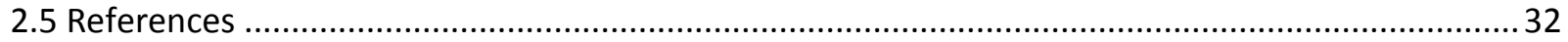

3 Policy or Markets? An Analysis of Price Incentives and Disincentives for Rice and Cotton in Selected

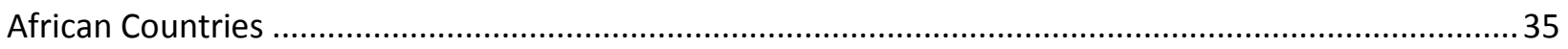

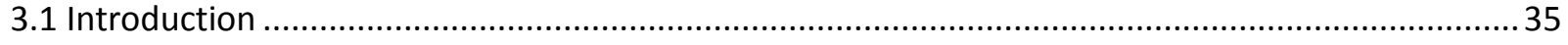

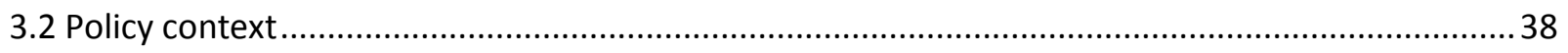

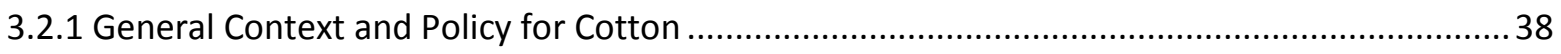

3.2.2 General Context and Policy for Rice .............................................................................. 42

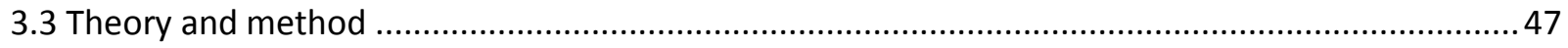

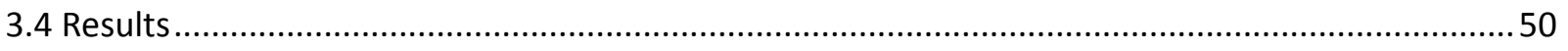

3.4.1 Results of the Analysis for Cotton ................................................................................... 50 


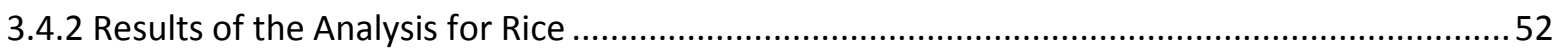

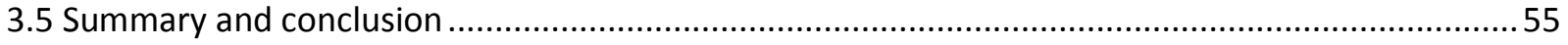

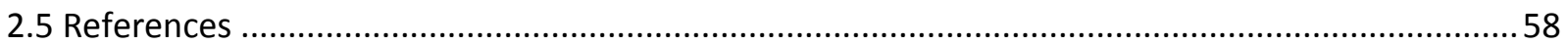

4 Myths and realities about inputs subsidies in Sub-Saharan Africa ...................................................64

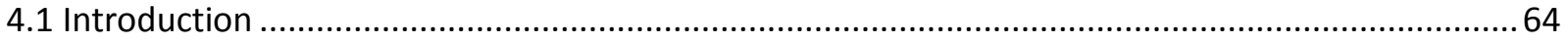

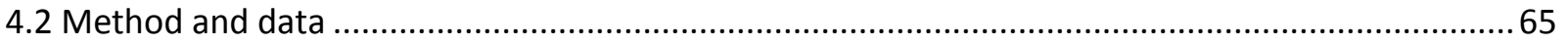

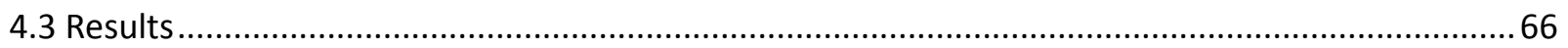

4.3.1 The share of input subsidies in agricultural budgets varies across countries.........................67

4.3.2 The composition of input subsidies is more diversified than usually thought .......................68

4.3.3 Input subsidies are embedded in agricultural budgets over time displaying no better execution

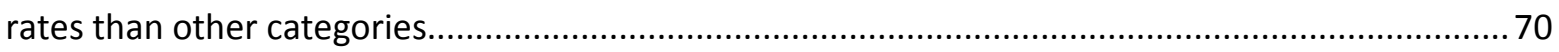

4.3.4 Aid tend to focus on other categories than input subsidies ................................................... 73

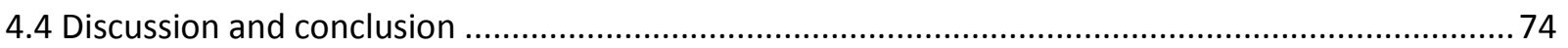

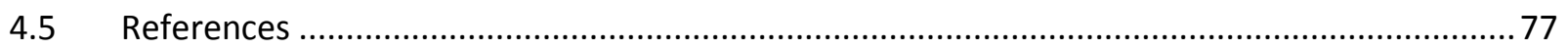

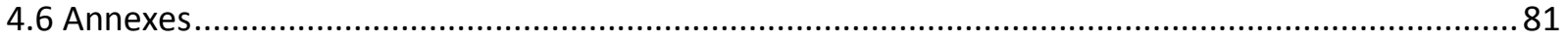

4.6.1 MAFAP classification of public expenditures in support of the food and agricultural sector ... 81

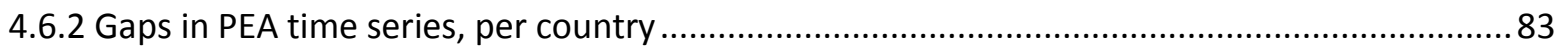

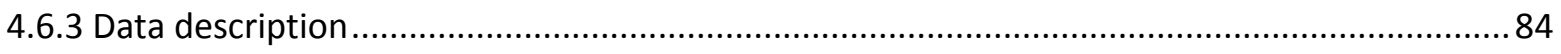

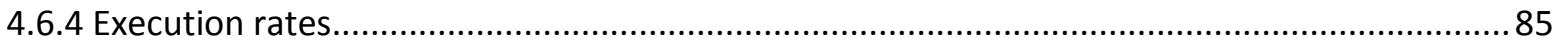

5 Price signals and supply responses for staple food crops in Sub Saharan countries............................. 86

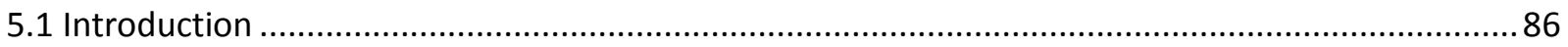

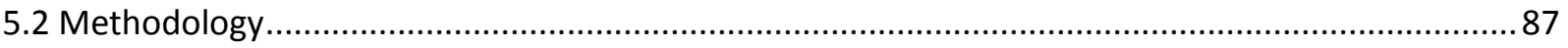

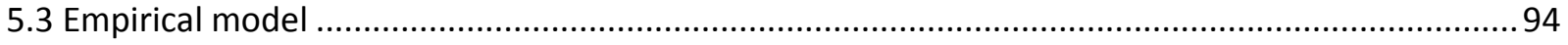

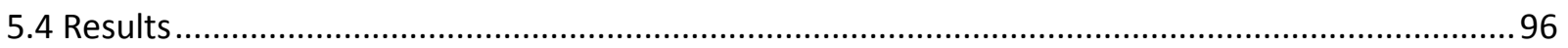

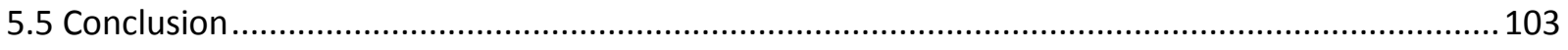

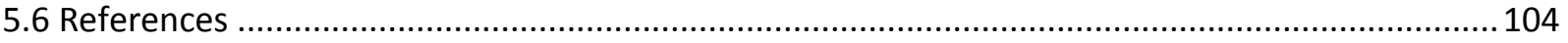

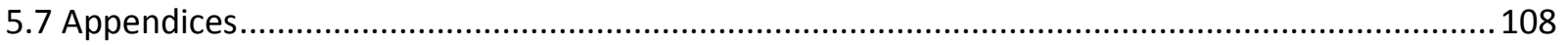

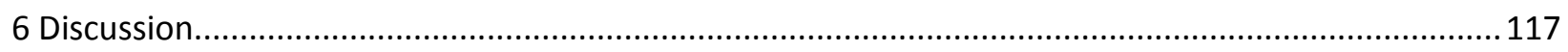

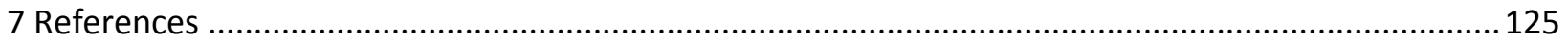




\section{List of figures}

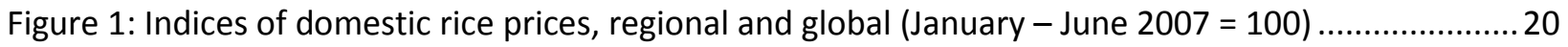

Figure 2: Indices of domestic maize prices, regional and global (January - June $2007=100$ )................. 20

Figure 3: Indices of domestic wheat prices, regional and global (January - June $2007=100$ ) ..................2 21

Figure 4: National domestic price index in 2013 and domestic price volatility, rice................................22

Figure 5: National domestic price index in 2013 and domestic price volatility, maize. ..........................22

Figure 6: National domestic price index in 2013 and domestic price volatility, wheat.............................23

Figure 7: Domestic price indices (weighted and unweighted) and world price index, rice......................27

Figure 8: Domestic price indices (weighted and unweighted) and world price index, wheat. ................. 27

Figure 9: Domestic price indices (weighted and unweighted) and world price index, maize..................28

Figure 10: Comparison of rice, wheat and maize domestic price indices with other food price indices. .. 29

Figure 11: Plot of NRPs versus theoretical NRPs.

Figure 12: Share of input subsidies over agriculture-specific expenditures (right axis), agricultural GDP and overall GDP (left axis) in nine African countries, average 2006-13.

Figure 13. Expenditures in support of on-farm services, capital and variable inputs for nine African countries, average for the 2006-13 period, constant 2011 USD per farm.

Figure 14: Average exponential growth of the expenditures per farm on input subsidies, research, knowledge dissemination and agricultural infrastructure (in constant 2011 USD) in nine African countries, 2006-13 period, in \%.

Figure 15: Share of national expenditures within total expenditures on input subsidies (IS) and selected public goods (PG, defined as the sum of ARE, KDE and AIE), average for the 2006-13 period, in \%. ........73 Figure 16: Average execution rates for input subsidies, donor and national expenditures, for seven African countries, 2006-13, in \%.

Figure 17: Percentage Coverage of the Total Food Supply, by country (avg. 2005-2013) ....................... 93

Figure 18: Price elasticity with and without marketing costs ............................................................. 100

Figure 19: Point Estimates with Alternative Maximum Lag Lengths for Instruments ........................... 111

Figure 20: Point Estimates with Alternative Maximum Lag Lengths for Instruments ............................ 112

Figure 21: Point Estimates with Alternative Maximum Lag Lengths for Instruments ............................ 113

Figure 22: Point Estimates using Alternative Econometric Models...................................................... 114

Figure 23: Point Estimates using Alternative Econometric Models.................................................... 115

Figure 24: Point Estimates using Alternative Econometric Models......................................................116

Figure 25: Average Nominal Rate of protection in 11 Sub Saharan Countries ...................................119

Figure 26: Nominal rates of protection, individual African focus countries, unweighted averages 2005-09

and 2010-14 120 


\section{List of tables}

Table 1: World and domestic real price changes (January - December 2013 versus January - June 2007)

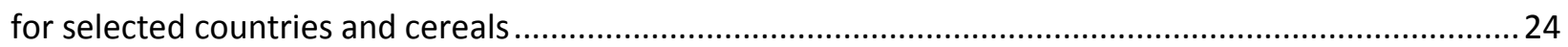

Table 2: Domestic price volatility by region by commodity (percent).....................................................25

Table 3: Policy measures employed regarding cotton value chains in the countries included in the study (2005-2010)

Table 4: Estimates of the sum of tariffs and other ad valorem charges affecting the landed cost of rice from the major import source of each country (\%).....

Table 5: Farm gate nominal rates of protection for cotton .................................................................50

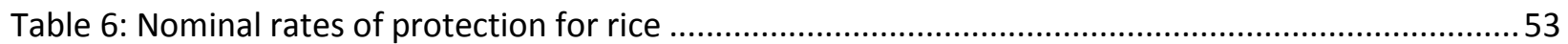

Table 7: Share of variable inputs, capital and on-farm services expenditures over agricultural-specific expenditures in nine African countries, average 2006-13.............................................................. 70

Table 8: Share of input subsidies within agriculture-specific expenditures in nine African countries, and input subsidies per farm in constant 2011 USD, average exponential growth rates over the 2006-13

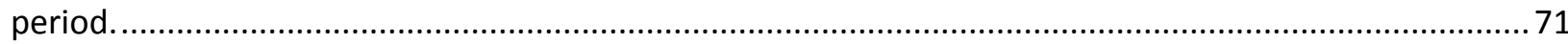

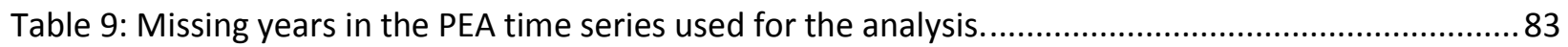

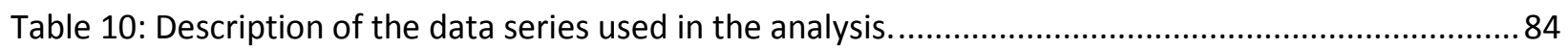

Table 11: Differential between the execution rates (ER) of input subsidies (IS), agricultural research expenditure (ARE), knowledge dissemination expenditure (KDE) and agricultural infrastructure expenditure (AIE) and the execution rates of agricultural-specific expenditure without said categories by funding source, in nine African countries, average over the 2006-2013 period, in \% ............................ 85

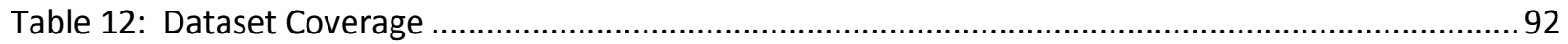

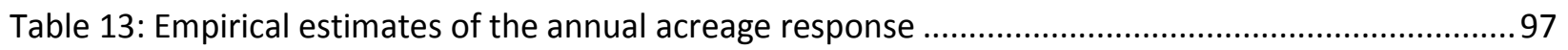

Table 14: Empirical estimates of the annual production response .......................................................98

Table 15: Empirical estimates of the annual yield response ................................................................99

Table 16: Data Sources for producer, wholesale, border prices and marketing costs ............................ 108

Table 17: Descriptive statistics of selected variables, by country (2005-2013)...................................... 109

Table 18: Unit Root Tests for Panel Data ............................................................................................. 110 


\section{Introduction}

\subsection{Motivations behind the research}

Most countries in the world adopt policies in support of their agricultural sector. In doing so, governments seek to influence farmers' behaviour through various channels. Trade and domestic market policies intend to affect the prices farmers receive for their produce or the price of inputs they purchase. Governments typically also use budgetary transfers to support specific agents either directly or indirectly through investments in public goods (research, infrastructure, etc.). While these policies and their incidence have long been monitored for member countries of the Organization for Economic Cooperation and Development (OECD), there is scarce literature on those provided by the developing countries and especially by Sub Saharan African (SSA) countries. This is largely because of the challenges in data availability and quality while a reliable and abundant dataset exists for OECD countries and a number of emerging economies. As a result, a substantial amount of research can, for example, be found for OECD countries on public expenditure in agriculture focusing on the efficacy and efficiency of input subsidies, or the return of public spending in agricultural research and infrastructure as opposed to transfer on private goods.

The scarcity of policy relevant information for the agricultural sector in SSA makes it difficult to explain whether the economic growth that the sub-continent has exhibited for the last two decades is at least partly due to suitable policy reforms underpinning a long term transformative process of the sector. The relatively slow progress to transform the agricultural sector from a dominance of self-subsistence farming to a more commercial oriented agriculture is attributed to several factors including high population growth rate, political instability, inadequate policy frameworks, lack of market access in many areas, weak agricultural research and extension systems in most countries (FAO, 2012; Hollinger and Staatz, 2015). While the pace of development of the sub-continent has accelerated in the last decade, Sub Saharan Africa has not yet realized its potential in terms of production level, productivity, and, ultimately, food security (FAO et al., 2015).

At the same time, agricultural and food policy reforms have been a constant feature in SSA for the last fifty years (Mellor et al., 1987; Friis Hansen, 2000; Kerallah et al., 2000; Kerallah et al., 2002). Indeed, just like in most other countries of the world, African governments have extensively intervened in markets through an array of regulations, price, trade, marketing policies or budgetary outlays to influence behaviour of economic agents (Wolf, 1979; Bates, 1981; Akiyama et al., 2003; Benson, 2004; Chamberlin and Jayne, 2011; Byerlee et al., 2013; Ricker-Gilbert et al., 2013). Overall, agricultural policies in SSA countries generated production disincentives for farmers (Quiroz and Valdes, 1993; Anderson and Masters, 2009) and were characterised by an anti-trade, anti-rural bias until the late 1990s, while many developed countries protected their agricultural sector. This trend was only gradually reversed in the middle of the 2000s. Then, the agricultural sector regained prominence in the development agenda (World Bank, 2007). The New Partnership for Africa's Development (NEPAD) of the African Union adopted the Comprehensive African Agricultural Development Program (CAADP) as the overall policy framework to steer its continent wide strategy for agriculture led development. In this context, the Maputo Declaration on Agriculture and Food Security called governments to allocate at least $10 \%$ of their national budget in support of agriculture and rural development to achieve at least $6 \%$ agricultural growth (African Union, 2003). This commitment was reaffirmed in the Malabo Declaration on accelerated agricultural growth (African Union, 2014). 
However, most governments in SSA have demonstrated a preference for short term trade, market, and price policies as opposed to long term investments in public goods (Demeke et al., 2009; Maetz et al., 2011; Demeke et al., 2014). The extent of reforms and their effects on price incentives for producers of key agricultural commodities have been questioned as they were not systematically quantified and assessed. The role of policies to stimulate food production and agricultural productivity in SSA has been subject to extensive discussions during the last decades (Townsend, 1999; Anderson, 2009; Sitko and Jayne, 2012). Due to limited reliable policy information, a number of technical and non-technical reasons have been proposed. Agricultural output growth is usually seen as the consequence of area expansion rather than productivity growth (Asenso-Okyere and Jemaneh, 2012). This situation contrasts with what happened in Asia where growth in agriculture was essentially due to increase in yields and South America where growth was sustained by increasing labour productivity (Bloom and Sachs, 1998; NEPAD, 2014). Moreover, as population growth in SSA outpaced production growth, most countries increased imports to respond to the rapidly expanding food demand.

Yet, isolating the main determinants of production decisions by farmers has proved very difficult (Baffes and Gardner, 2003). As such, the issue of whether internal or external factors are the main drivers behind the weak production response of farmers in the region (Hall and Jones, 1997 and 1999; Di Marcantonio et al, 2014; Hollinger and Staatz, 2015) is still far from being closed in the development literature (Clover, 2003; Nin-Pratt and Yu, 2009; Onal, 2012). However, there seems to be a certain degree of consensus around a juncture of factors that are necessary to enable farmers to respond to market signals including effective price transmission (Baffes and Gardner, 2003; Meyer and von Cramon-Taubadel, 2004; Dawe et al., 2015), adequate macroeconomic, trade and domestic policies (Krueger, Schiff, and Valdés, 1991; Quiroz and Valdés, 1993; Anderson, 2008; Anderson and Masters, 2009; Nin-Pratt and Yu, 2011; Sitko and Jayne, 2012), supportive structural and institutional frameworks (Knack and Keefer, 1995; Keefer and Knack, 1997; Hall and Jones, 1997; Hall and Jones,1999; Poulton et al., 2006), easier access to complementary inputs, credit, and extension services, and investments where basic rural infrastructures are missing or appear underdeveloped (Bates, 1983; Sadoulet and de Janvry, 2000; Kherallah et al., 2002; Barret, 2008; Jacoby and Minten, 2009; Mason et al., 2013; Ebata et al., 2015).

Throughout these decades of policy changes, it has been difficult to assess the effectiveness of the various policy reforms as no system was available to systematically and continuously measure the effects of policy interventions on the basis of comparable indicators across countries and over time contrary to what existed since the 1980s for the OECD countries (Angelucci et al., 2013). In this respect, the work proposed by Kym Anderson as part of the World Bank's research project on Distortion to Agricultural Incentives (DAI) constituted a major breakthrough (Anderson and Masters, 2009). It was then possible to confirm whether SSA countries were gradually moving away from situation of net taxation of agriculture. In the same spirit, FAO's Monitoring and Analysing Food and Agricultural Policies (MAFAP) programme started in 2009 with the objective of establishing country owned and sustainable systems to monitor, analyse, and reform food and agricultural policies to enable more effective, efficient and inclusive policy frameworks in support of agricultural development in a growing number of developing and emerging economies. 


\subsection{Objectives and research topics of the study}

In this context, the overall topic of this dissertation is about better understanding the level and composition of policy support to agriculture in SSA countries, its effects on agricultural production incentives and on market distortions. Most of the research underpinning this dissertation has focused on policy interventions essentially in the form of market price support or budgetary transfers, and their combined incidence on transmission of market price signals between the international markets and the farms, agricultural production incentives and the resulting supply response.

The main research questions addressed in this dissertation are as follows: Are international price signals actually transmitted to farmers in developing countries? Are there any price behaviour specificities in SSA with respect to other regions of the world? Are policies adopted by governments, for example, in response to price shocks in international markets, actually altering price signals? Are observed market distortions in SSA primarily the result of policy or market failures? Are some forms of public support, such as inputs subsidies, more problematic than others and why? What are the combined effects of market price signals and policy interventions on the supply response of farmers in SSA? Are farmers in SSA actually able to respond to higher prices with increased production? Are there other factors beyond market price and policy support driving production decision by farmers?

All the research activities in the context of this dissertation have taken the form of empirical analyses and have primarily built upon the quite recent dataset developed by FAO's Monitoring and Analysing Food and Agricultural Policies (MAFAP) programme, complemented by the FAO's Food Price Monitoring and Analysis (FPMA) Tool which provides a comprehensive dataset on prices at wholesale and retail levels. The added value of the MAFAP database is that it proposes a set of comparable indicators measuring the incidence of policies and market performances for farmers and other agents in different commodity chains, across SSA countries and over time (Balié and Maetz, 2011; FAO, 2014).

As analysing the effects of policies on production incentives in SSA is a very broad research topic that could not be covered in an exhaustive manner through one dissertation only, it was decided to decompose this overall research in four components. As a result, the focus of the research has gradually and sequentially shifted from (a) the role of policies in the transmission of price signals from international to domestic markets (essay 1 ), to (b) the respective importance of policy and market failures in generating distortions to production incentives (essay 2), to (c) a discussion on the specifics of inputs subsidies as a typified and controversial form of producer support extensively used in SSA (essay 3), to (d) the final discussion on the supply response to price signals and other factors across nine SSA countries (essay 4).

\subsection{Outline of the chapters}

Chapters 2, 3, 4, and 5 form the main body of this dissertation and present the various aspects of the research in details.

Chapter $\mathbf{2}$ investigates the respective roles of policies and market failures in transmitting, amplifying or muting price signals received by farmers and arising from the international market through changes in production incentives. Taking the case of cereals, the objective of this essay is to analyse available price data to describe the behaviour of domestic staple food prices since the world food price crisis in 2007/08, including comparisons across regions and countries. The chapter successively discusses (i) the broad patterns of domestic prices since 2007, including an assessment of how much domestic 
staple food prices have increased since that time; (ii) the variability across regions and countries, as well as variability over time within countries (i.e., domestic price instability); (iii) a comparison of price movements in world and domestic markets; and (iv) a comparison of the domestic price indices with other food price indices.

Based on domestic price data (adjusted for inflation) from a large range of low- and middle-income countries, results show that domestic staple food prices were higher in 2013 than they were in the first half of 2007: consumption-weighted real domestic rice, wheat and maize price indices increased by 19, 19 and 29 percent, respectively. The domestic price indices broadly followed world price movements, but domestic price changes were attenuated to an important extent due to government policies, transport costs, changes in exchange rates and other factors. While world price changes thus overstate the impact on food security of farmers and consumers, the observed increases in domestic prices were still substantial for the poor. Domestic price changes have varied widely across countries, and the changes in any particular country were not necessarily due to changes in world market prices.

Chapter 3 presents an empirical analysis of the nature of the distortions to production incentives arising from either policy or market failures. Using data from the MAFAP programme, this chapter reports nominal rates of protection (NRPs) for rice and cotton at wholesale and farm level across nine countries and between 2005 and 2010. Rice and cotton are two key commodities in SSA. Rice is typically an import substitute that has received high levels of border protection by the governments concerned while cotton is a key export crop which has been the focus of direct and indirect public interventions.

For both commodities, the chapter provides evidence of both market and nonmarket failures. In the case of rice, these prevent border protection from reaching farmers while raising consumer prices. Cotton ginning and marketing is concentrated in a small number of private sector companies in most countries studied. The farm level NRPs provide evidence of market failures in these countries that may be mitigated by policies that set indicative prices and encourage competition. Interestingly, the NRPs point at non market failures in the two countries that maintain parastatal monopsonies for cotton.

Chapter 4 investigates input subsidies as one of the most common policy option governments in SSA countries adopt to pursue their objective to support agricultural production growth. The chapter starts by recognizing the body of literature pointing at the policy failures resulting from unreasonable or misguided choices made by some African governments spending too much of their scarce resources on input subsidies at the expenses of other categories that would support agricultural growth and development more effectively and more sustainably. However, such strong conclusions are often insufficiently based on reliable, comparable and detailed evidence on the level and composition of spending on input subsidies. Using the dataset compiled by the MAFAP programme, this chapter examines the trends of input subsidies in terms of level, composition and budget execution rates in nine African countries between 2006 and 2013

Results show that input subsidies (i) received close to $35 \%$ of agricultural-specific expenditures on average, (ii) tended to get stuck into agricultural budgets over time exhibiting sub-optimal execution rates, (iii) were primarily funded by national taxpayer while donors invested more on public goods. Findings confirm that input subsidies crowded out other spending categories likely more supportive of long-term agricultural development objectives. The chapter concludes that the political economy of input subsidies should lead to more concrete efforts to increase their efficiency and their policy coherence rather than seek their abolition.

Chapter $\mathbf{5}$ focuses on estimating the supply response to price signals and other factors such as policy incentives. While several studies already estimated the supply response of farmers in SSA, this 
literature has used a variety of approaches and has generally concluded that price elasticities of supply were low or very low. However, only a few analyses have gone beyond estimating the aggregate supply response for the sector as a whole or the specific case of cash crops. In most cases, data scarcity especially on producer prices has been the main limiting factor. In this chapter, this question is revisited by focusing on the supply response of main staple food crops in selected SSA countries. The chapter builds upon the MAFAP dataset which provides prices at the producer, wholesale, and border levels for selected value chains. Using dynamic panel techniques, it is possible to test how acreage, production and yields respond to price signals and other non-price factors over a period (2005-2013) that includes the last two major food price crises.

Results show that farmers producing staple food crops react to real price signals, even if with a limited intensity. Moreover, direct price incentives arising from border protection and government intervention in domestic markets and price shocks at the border also influence farmers' decisions and are more important than macroeconomic policies. Results also show that omitting marketing costs from the supply response function leads to an underestimation of the price elasticity. Conversely, using wholesale instead of farm gate prices as proxy for producer prices leads to an overestimation of the price elasticity of supply.

Chapter 6 provides an overall discussion including a summary of the results and possible policy implications. 


\section{International versus domestic price signals ${ }^{1}$}

\subsection{Introduction}

There have been major changes in the world food economy over the past few years: oil prices were substantially higher from 2008 - 2013 than they were in the preceding two decades, biofuels demand has grown (see de Gorter et al, 2013 and Tyner, 2013 for differing views on how important this has been for the level of grain prices) and price volatility seems to have increased (with two major cereal price spikes, one in $2007-2008$ and one in 2010 - 2011). At the same time, population growth continues (albeit at a slower growth rate than in the past), scarcity of natural resources such as land and water is getting worse, urbanization is reducing labour supplies in the countryside and economic growth in developing countries is leading to greater demand for livestock products that require large quantities of cereal as feedstock (Conforti, 2011). Last, but not necessarily least, climate change presents major uncertainties for agricultural production. These trends have led many to suggest that we are in an era of higher and/or more volatile food prices (e.g., Naylor and Falcon 2010; Dupont and Thirlwell 2009; Irwin and Good 2009; OECD-FAO 2014).

When discussing higher food prices, reference is typically made to world prices denominated in US dollars. For developing countries, world market prices are crucially important for import bills, foreign exchange earnings, and as signals to guide resource allocation. But it is well-known that changes in world market prices are not always transmitted into changes in domestic prices due to transport costs, government policies, changes in exchange rates and market failures such as imperfect information (Hassouneh et al, 2012; Conforti, 2004; Timmer, 1993; Dawe, 2009; Minot, 2010; Rapsomanikis, 2011; Short et al, 2014; Baquedano and Liefert, 2014). Furthermore, it is domestic prices that affect poverty and welfare, because these are the prices actually received by farmers and paid by consumers. These observations suggest that it is important to understand the behaviour of domestic food prices in addition to global prices, in particular since the world food crisis of $2007-2008 .^{23}$

When analyzing food prices, it is particularly important to understand the behaviour of cereal prices (as distinct from prices of meat, dairy, fruits, vegetables and other foods), because cereals are the most important expenditure item for the poor and food insecure, typically accounting for 50 percent of dietary energy supply and $20-25$ percent of total expenditures for people in the bottom quintile of the income distribution (FAO, 2011). In addition, even though cereals are often missing many key micronutrients, cereal prices are crucial for nutrition because higher cereal prices can crowd out expenditures on more nutritious foods such as eggs, milk and green leafy vegetables (Block et al, 2004; Torlesse, 2003; de Brauw, 2011). In this paper, we focus on the three main cereals consumed by humans: rice, wheat and maize.

In the wake of the world food price crisis of $2007-2008$, there has been a strong effort to collect data on domestic food prices. FAO has put substantial effort into constructing a database of domestic wholesale and retail prices for a number of food items for a large number of countries, and this database is freely

\footnotetext{
${ }^{1}$ This paper is a joint work with three FAO colleagues David Dawe, Cristian Morales Opazo, and Guillaume Pierre, published under the title "How much have domestic food prices increased in the new era of higher food prices?" in July 2015 in Global Food Security, Vol. 5: 1-10.

${ }^{2}$ Just like world prices, domestic prices also influence resource allocation.

${ }^{3}$ We do not address the impact of food prices on poverty, which has been addressed elsewhere (Barrett and Bellemare, 2011; Ivanic et al, 2011; Robles and Torero, 2010; Headey, 2014; Dawe et al, 2010; Dorward, 2012).
} 
available (FAO, 2014a) $)^{4}$. The ultimate data sources in most cases are official government sources (full details of specific sources for each country are available in FAO, 2014a).

The objective of this paper is to analyze these data to describe the behaviour of domestic staple food prices since the world food price crisis, including comparisons across regions, countries and the three cereals. After a description of the data and the methods used to analyze them, the remainder of this paper is split into four main sections: (i) broad patterns of domestic prices since 2007, including an assessment of how much domestic staple food prices have increased since that time; (ii) variability across regions and countries, as well as variability over time within countries (i.e., domestic price volatility); (iii) a comparison of price movements in world and domestic markets; and (iv) a comparison of the domestic price indices calculated here with other food price indices. These data and comparisons provide an assessment of the magnitude of domestic staple food price changes since the world food crisis.

\subsection{Data and methods}

The focus of this paper is on wholesale and retail prices, which are best viewed as consumer prices. This focus on the consumer is mandated by the scarcity of farm-level price data, which are not included in FAO (2014a). Collection of more frequent and systematic farm-level price data should be a major priority for understanding supply response and the food security of farmers who receive income from crop sales. ${ }^{5}$ The focus of this paper is also on low- and middle-income countries (LMIC), where food constitutes a larger share of household budgets and high prices are more of a food security concern (Regmi and Meade, 2013).

Since our objective is to assess cereal price changes as experienced in LMIC, we measure price changes in local currency (LC) terms. Using local currency prices has the disadvantage that we cannot calculate an average price level across countries, since it is not possible to compare price levels if the prices are in different currencies. But the advantage is that price changes are then measured in a manner that is relevant to domestic consumers, as exchange rate movements and other factors can lead to very different price changes in local currency and US dollar terms (FAO, 2011; Dorward, 2011).

Our first step was to bound the period of analysis. Starting the analysis in 2006 would have excluded a very large number of countries, while extending it into 2014 would have encountered a number of data gaps at the time of analysis. Thus, we analyze data over the period January 2007 to December 2013.

The database in FAO (2014a) is extensive: there are data for wholesale and retail markets, for different qualities, different forms (e.g. grain and flour), and different cities/locations, although not all types are available for a given commodity in a given country. But there are numerous cases of missing values in many of these series. In order for a specific data series to be considered, we decided that it must have no more than two consecutive missing data points. In four cases, however, we made an exception to this rule in order to avoid discarding a commodity/country combination entirely: the best available data series for those four commodity/country combinations had at most six consecutive missing data points. In cases where there were four or fewer consecutive missing data points, linear interpolation between adjacent data points was used to fill in the missing values. In the other two cases where there were five or six

\footnotetext{
${ }^{4}$ Thanks are due to Anthony Burgard, Youngran Choi, Cheng Fang, and FAO-GIEWS staff including Liliana Balbi, Fabio Palmieri and Paul Racionzer for their help in collecting and compiling the data used in this analysis. Thanks are also due to participants at an FAO seminar on this topic, who provided many helpful suggestions.

${ }^{5}$ FAO (2014b) and FAO (2014c) have helpful data on farm prices, but they are annual, not monthly.
} 
consecutive missing data points, seasonally adjusted linear interpolation was used to fill in the data gap. Price series with data gaps longer than 6 months were dropped.

Once the pool of "eligible" data series was determined, our first step was to select the data to be used for each country/commodity combination, because data are often available for multiple locations, multiple qualities or multiple marketing levels for a given staple food in a given country. We term each specific country/commodity combination (e.g. Kenya maize) a "case study." In order to choose which data series to analyze for a given case study, a set of ordered selection criteria were applied. Our first criterion was to use, whenever possible, retail price data (58 case studies), the justification being that these are the prices paid by consumers. However, if no retail price data were available for a particular case study, we used wholesale prices ( 45 case studies), which are usually linked quite closely to retail prices. In the case of wheat, if there were data for both wheat and wheat flour, we used data on wheat flour on the grounds that it is closer to the ultimate form in which it is consumed. Overall, we used data on wheat flour in 17 case studies, and data on wheat in 10 case studies.

Our second criterion was based on quality. We chose the lowest quality available, on the grounds that lower qualities are more important for the poor. That being said, prices of different qualities generally seemed to move broadly together within the same country.

Our third criterion was to use national average prices when available. When national average prices were unavailable, we used a weighted average price across all the markets in the given country for which data were available, using population weights obtained from Brinkhoff (2014), which collates demographic data from numerous national census bureaus. There were 30 case studies for which national average data were available, and an additional 21 case studies for which we calculated an average based on three or more locations. For the other 52 case studies, we used data from one (42 cases) or two (10 cases) locations in the country.

Application of these criteria leads to a total of 103 case studies of cereals distributed across 59 countries. There were 44 country case studies for rice, 32 for maize and 27 for wheat/wheat flour. For rice, wheat and maize respectively, our country coverage accounts for 92,67 , and 54 percent respectively of direct human food consumption ${ }^{6}$ in LMIC. In all LMIC, including those for which we do not have price data, rice has the greatest total consumption among the three major cereals at 352 million tons (milled basis), followed by wheat at 337 million tons, with maize a distant third at 111 million tons.

After selecting the data series to analyze, our second step was to transform data on nominal domestic cereal prices into real terms by dividing by the domestic consumer price index (CPI) (IMF, 2014), which adjusts for the impact of inflation that tends to raise all prices and wages over time. Such an adjustment is essential when examining price behaviour over a period of seven years, because domestic inflation often exceeds 10 percent per year in LMICs (at such a rate, prices will double in seven years). Ideally, we would like to divide the nominal price by a CPI that excludes the commodity in question, because such a procedure would give the true relative price increase of a given commodity. Such data are rarely available, however, so we divide by the aggregate CPI. When the real price of a commodity increases, use of the aggregate $\mathrm{CPI}$ in constructing the real price understates the true magnitude of the price increase relative to other commodities (Dorward, 2011 terms this the "denominator effect"). The magnitude by which the

\footnotetext{
${ }^{6} \mathrm{FAO}$ estimates human food consumption as a residual within a food balance sheet that utilizes data on or estimates of production, imports, exports, stock changes, feed, seed, industrial and other uses.
} 
price increase is understated is greater if the share of the commodity in question in the CPI is relatively high, which will more often be the case in poor countries. ${ }^{7}$

Because data are available for a large number of countries, it is useful to calculate some aggregate measures of the magnitude of changes in domestic cereal prices. To do this, we transform each series of real local currency prices into an index with base 100 in January - June 2007. We use January - June 2007 $=100$ rather than $2007=100$ because for wheat, world market prices began to surge in May 2007, and we want our base period to be before the price shocks hit domestic markets. Ideally, it would be best to go back even further in time to 2005 or $\mathbf{2 0 0 6}$ for the base period, but doing so substantially reduces the number of countries for which we have data.

These national indices are then combined to form a composite index that incorporates all of the countries in the database, using as weights the share of consumption of each country in total human consumption of each cereal in LMIC in 2011 (the most recent year available). Because we do not have price data for all LMIC, we rescale the weights to sum to 100 for each cereal. Composite sub-indices are also calculated for Africa, Asia and Latin America.

\subsection{Results and discussion}

\subsubsection{Broad patterns in domestic prices since 2007}

Our calculated composite indices for rice, wheat and maize (Figure 1; Figure 2; Figure 3) show that, comparing January - June 2007 with 2013 (annual average for 2013), (weighted) average real domestic prices in low and middle income countries increased by approximately 19 percent for rice and wheat and 29 percent for maize. For all three of the commodities, domestic prices had increased by the middle of 2008. But the increases were much less for wheat (which reached a local peak index value of 114 in May 2008) and rice (a local peak index value of 119 in August 2008) than they were for maize, which reached a local peak index value of 140 in July 2008.

One key reason for the difference between commodities is that the three largest LMIC (China, India, and Indonesia) insulated their domestic cereal prices from the world market by restricting/banning exports. Such a policy, if implemented effectively, can prevent domestic prices from rising (for details of the policies in these three countries, see Fang, 2010 for China; Gulati and Dutta, 2010 for India; and Syaifullah, 2010 for Indonesia). At the same time, such policies cause world price increases to be larger than they would have otherwise been (Anderson, 2012), leading to more pressure on domestic prices in other countries that are not able to insulate themselves from world markets so easily. These three large countries account for 71 percent of our composite index for rice and 73 percent for wheat, but only 17 percent of our maize index due to lack of data for India and Indonesia. The lack of maize price data for these two countries is unfortunate, but it is also true that maize is much less important as a human food in these countries compared to rice and wheat - we estimate that these three countries account for 65 and 50 percent of direct human consumption of rice and wheat in LMIC, but less than 20 percent of direct human maize consumption in LMIC.

\footnotetext{
${ }^{7}$ Dorward (2011) rightly argues that changes in nominal prices must be compared to something, and, in addition to the CPI, suggests other possible metrics: income, prices of other farm commodities, and farm input prices.
} 
Figure 1: Indices of domestic rice prices, regional and global (January - June $2007=100$ )

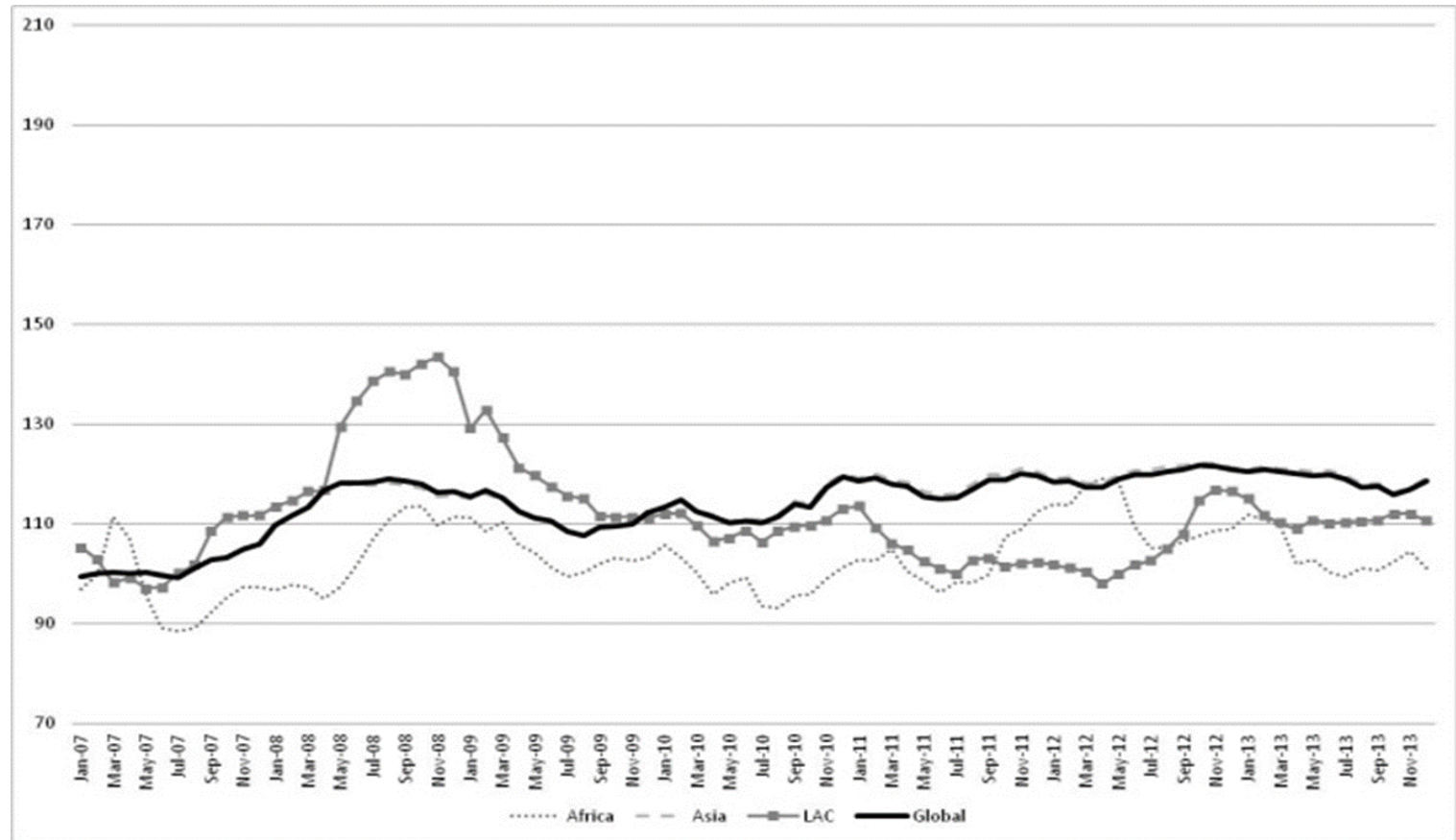

Note: The index for Asia is nearly identical to the global index and is thus hard to see.

Figure 2: Indices of domestic maize prices, regional and global (January - June $2007=100$ )

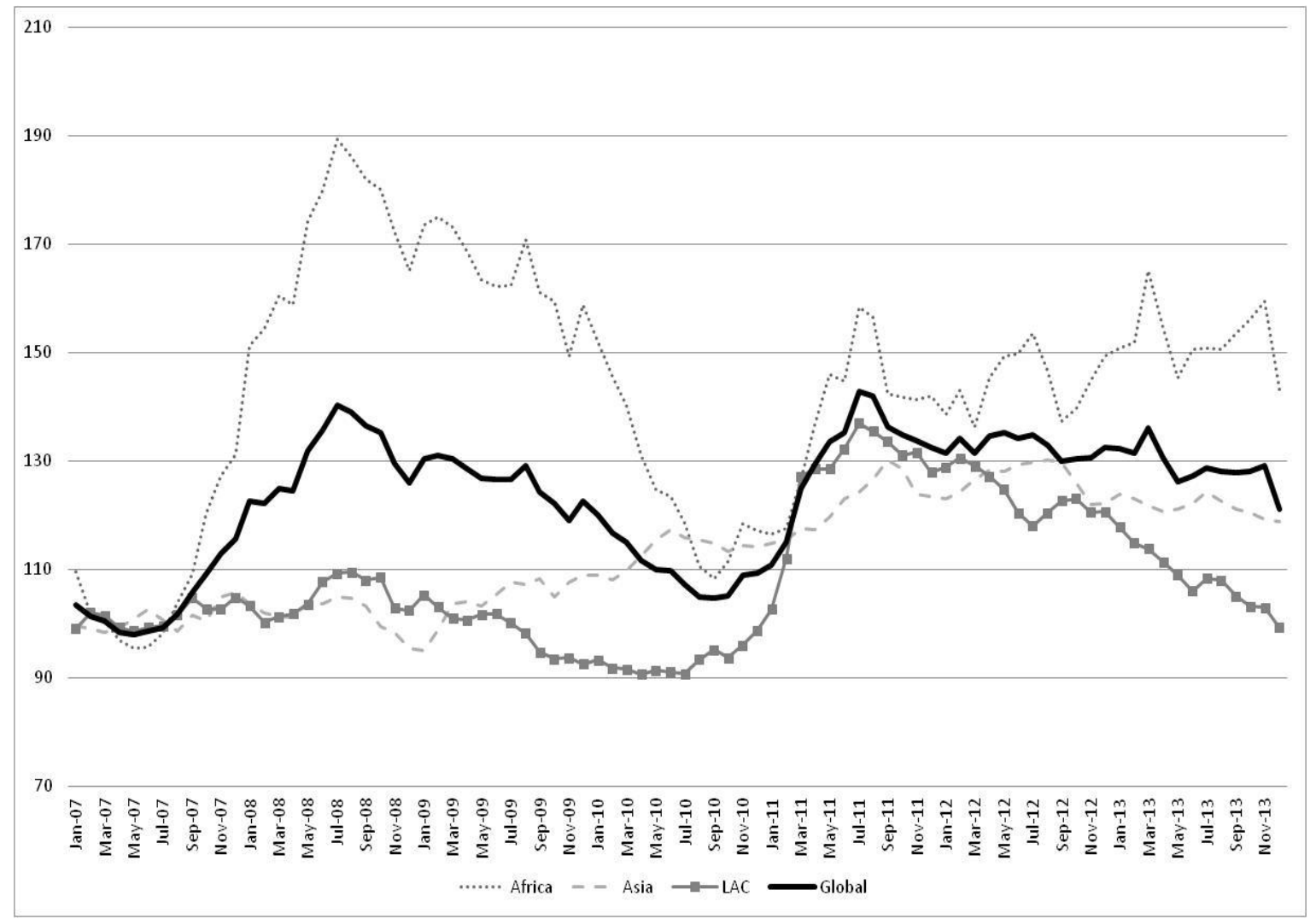




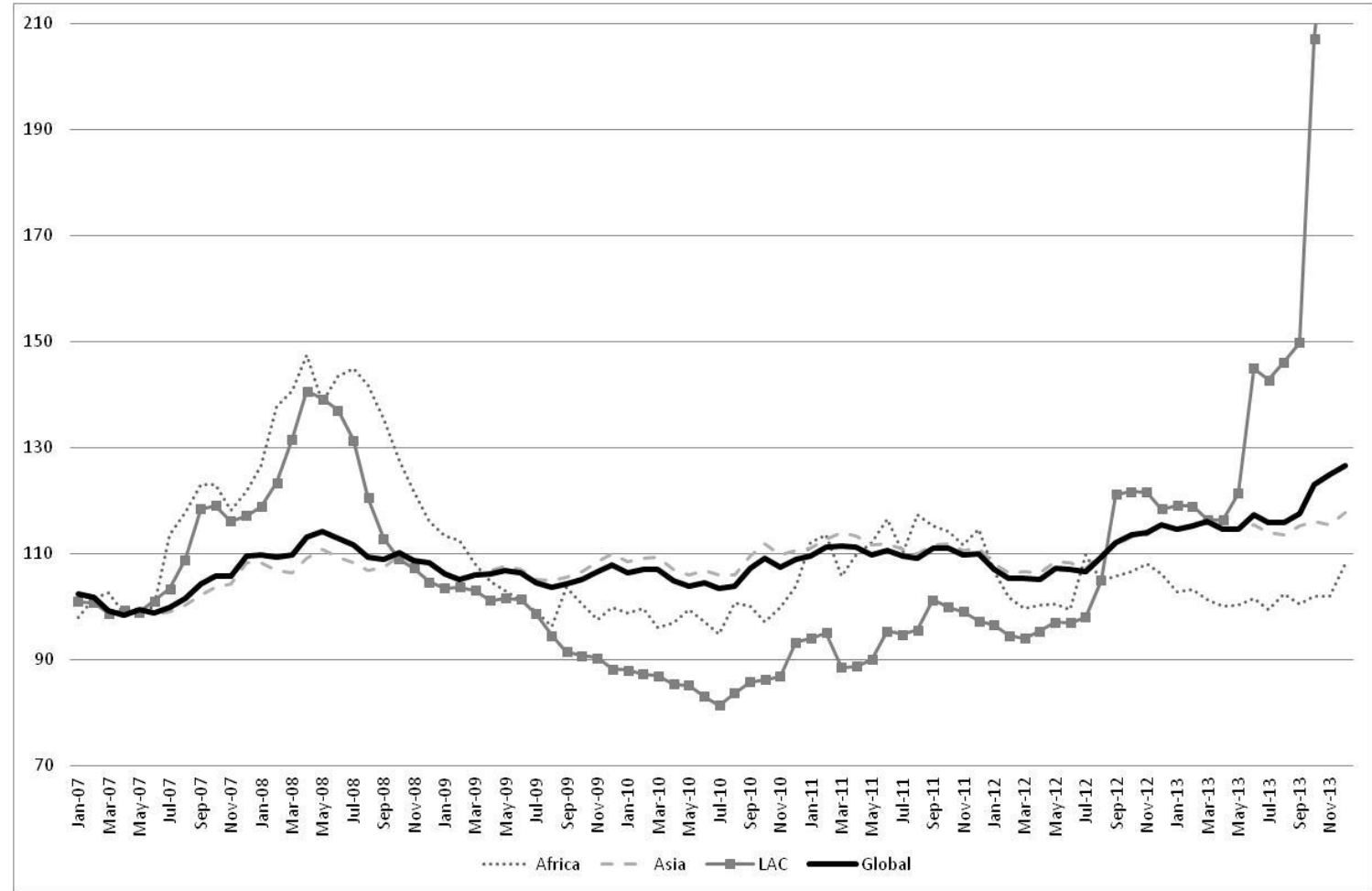

Note: The vertical axis has been truncated at 210 in order to avoid flattening the indices other than LAC and maintain the same scale as used in Figures 1a and 1c. The values for November and December 2013 for LAC are 234 and 227. This spike in the LAC price index in late 2013 is due to a price spike in Argentina, where domestic prices surged due to a $45 \%$ decline in production that led to a massive drawdown in stocks. This surge was temporary: prices declined sharply in 2014.

By July 2010, the composite indices for all three commodities had declined compared to 2008, and were close to levels in the first half of 2007. But another shock to world cereal markets (this time confined to wheat and maize) led to increases in domestic prices once again. Again, maize was the most affected, with the composite index rising to 143 in July 2011.

\subsubsection{Variability across regions/countries and over time}

While the level of domestic market prices in 2013 was generally higher than it was before the world price shocks, this has not been true in all countries - indeed, the variability across countries is striking (see Figure 4, Figure 5, Figure 6, and Table 1). Across all the 103 case studies for all three staples, 28 percent had lower real prices in 2013 than in the first half of 2007 - this percentage is roughly similar across crops. Thus, while domestic prices have broadly trended upward since 2007, there are many exceptions, highlighting the importance of country-specific analysis (e.g. Abdulai, 2000; Bakhshoodeh, 2009; Balcombe et al, 2007; Baquedano et al, 2011; Burke and Myers, 2014; Cudjoe et al, 2010; de Janvry and Sadoulet, 2010). 
Figure 4: National domestic price index in 2013 and domestic price volatility, rice.

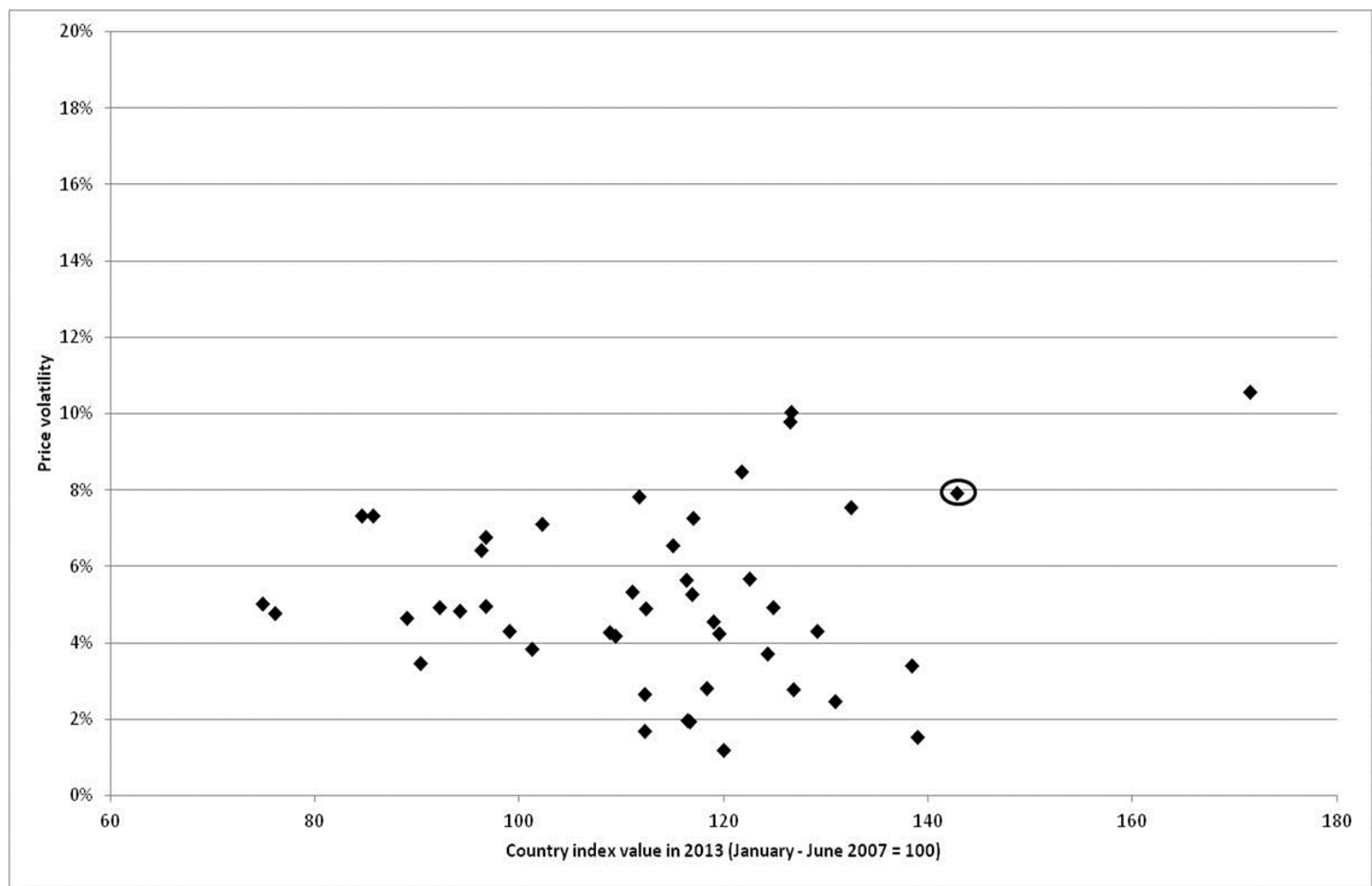

Note: The circled point represents world market prices.

Figure 5: National domestic price index in 2013 and domestic price volatility, maize.

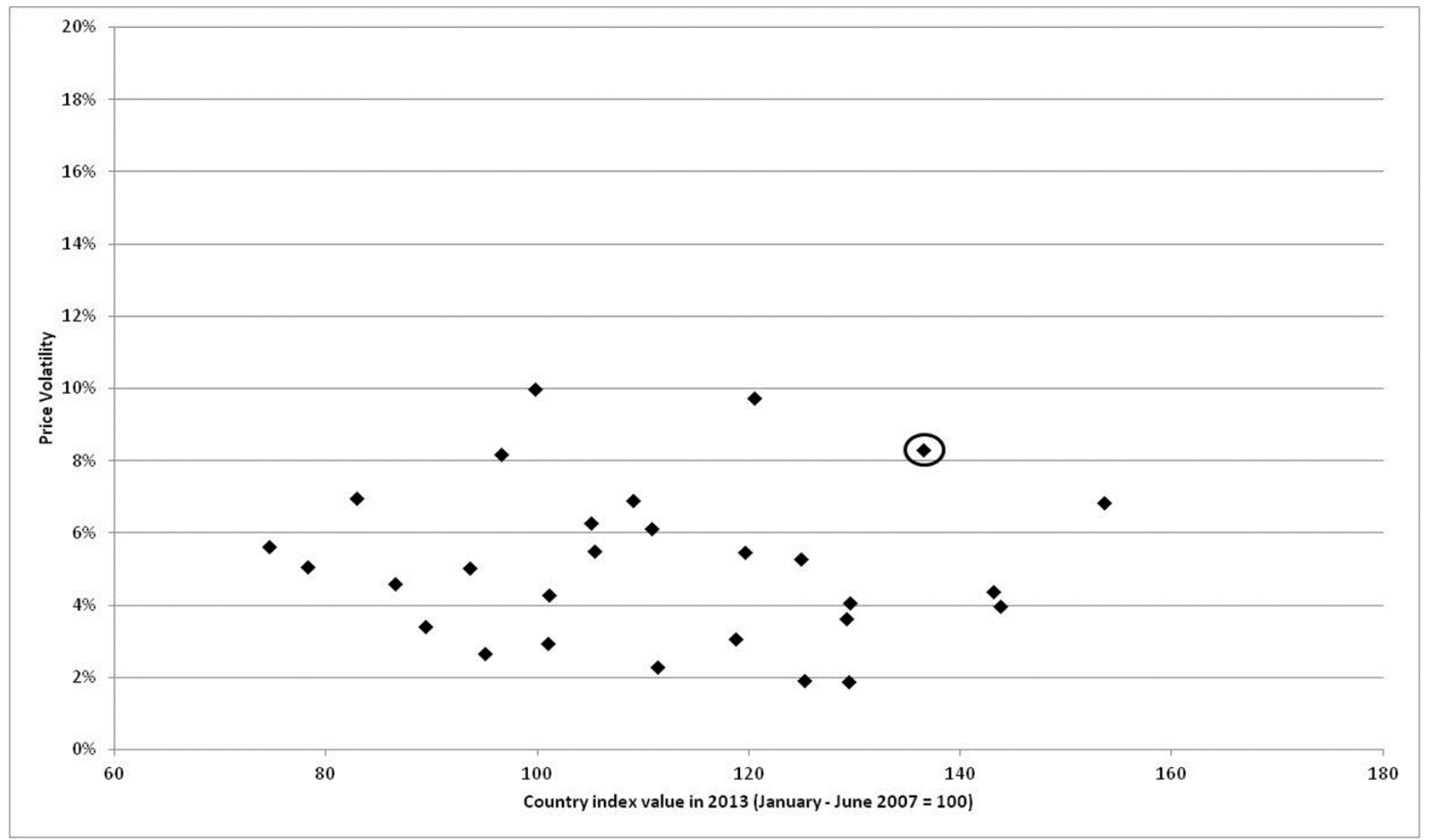


Notes: The circled point represents world market prices. Tanzania (220, 11.7\%) and Malawi $(274,12.1 \%)$ have been omitted from the scatter to show the other values more clearly and to keep the scale identical with the scale in Figures $2 a$ and $2 b$.

Figure 6: National domestic price index in 2013 and domestic price volatility, wheat.

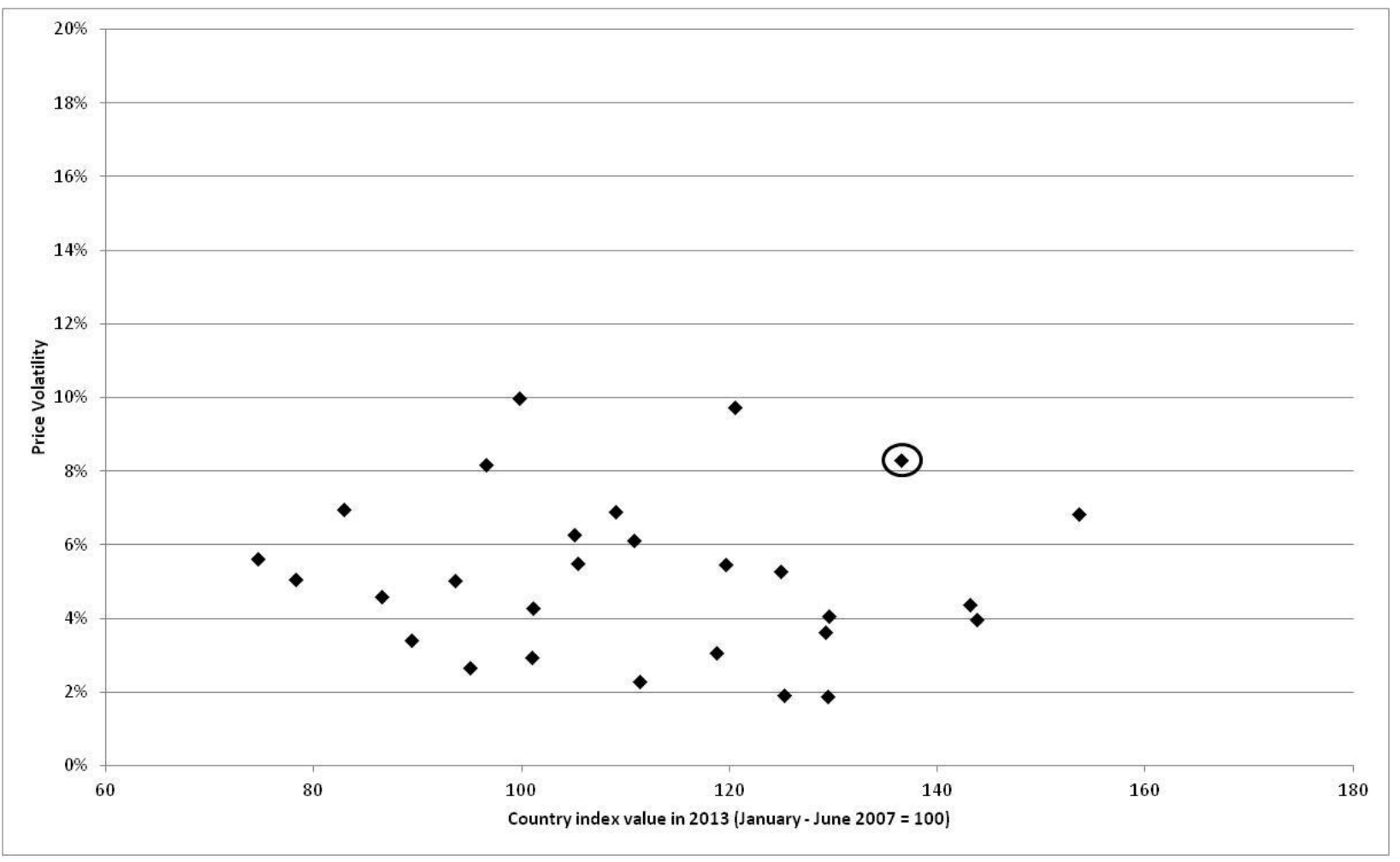

Notes: The circled point represents world market prices. Argentina $(334,10.8 \%)$ has been omitted from the scatter to show the other values more clearly and to keep the scale identical with the scale in Figures $2 \mathrm{a}$ and $2 \mathrm{c}$. 
Table 1: World and domestic real price changes (January - December 2013 versus January - June 2007) for selected countries and cereals

\begin{tabular}{llllll}
\hline Country & Cereal & Market & $\% \Delta \mathrm{P}_{\text {world }}$ (USD) & $\% \Delta \mathrm{P}_{\text {world }}$ & $\% \Delta \mathrm{P}_{\text {domestic }}$ (LC) \\
& & & & $(\mathrm{LC})$ & \\
\hline China & Rice & Whl, 2 provinces & 15 & -15 & 39 \\
Philippines & Rice & Ret, National & 15 & -12 & 18 \\
Bangladesh & Rice & Whl, National & 15 & -10 & -8 \\
India & Wheat & Ret, 4 cities & 36 & 17 & -5 \\
Brazil & Wheat & Whl, National & 36 & 16 & 1 \\
Peru & Wheat & Whl, National & 36 & 7 & 1 \\
Nigeria & Maize & Whl, 1 city & 39 & 0 & 38 \\
Ghana & Maize & Whl, 6 cities & 39 & 59 & 40 \\
Mexico & Maize & Whl, 5 cities & 39 & 41 & 15
\end{tabular}

Note: All price changes are in real terms, adjusted using the US CPI for world market prices (in US dollars, USD) and using national CPIs for local currency (LC) prices.

For example, in Bangladesh, real domestic rice prices in 2013 were 8\% lower than in the first half of 2007. This is similar to the change in world prices in real local currency terms, as Bangladesh has a relatively open rice trade policy that allows the private sector to arbitrage price differentials with external markets (Dorosh, 2009). ${ }^{8}$ But in China and the Philippines, despite a decline in world rice prices measured in real LC terms, domestic prices have increased substantially due to rising costs of production and various support policies (see Gale, 2013 for China and Briones and Galang, 2014 for the Philippines), as well as an unwillingness to source cheaper supplies from world markets. This diversity of policies shows that the general increase in real domestic cereal prices in many countries that is captured in our index is not necessarily due to higher world market prices: more open trade would have led to lower domestic prices in many countries (as well as higher prices on world markets).

There are many other examples of policy changes. In Mozambique, import tariffs on cereals were reduced substantially in 2008 , and have subsequently been maintained at the new lower levels. Temporary policies also of course affect domestic prices, e.g. export bans (Tanzania maize in 2011) and public stock releases (Ghana maize in 2011). And foreign exchange policy can play a role, especially where these markets are thin, as in Ethiopia where the central bank reduced allocations of US dollars to wheat and maize importers in 2008, aggravating the effect of the world price shock on domestic markets. The key message is that domestic prices are driven by domestic policies in addition to world prices.

\footnotetext{
${ }^{8}$ Note the large difference between changes in world prices in terms of real US dollars and in terms of real local currency in Table 1. In recent years, due to (real) depreciation of the US dollar against a wide range of developing country currencies, the change in world price in local currency terms has been smaller than in US dollar terms. Dorward (2011) provides additional arguments (other than real exchange rate changes) why real prices in US dollar terms are not globally applicable.
} 
Price volatility also varies across commodities and countries. Domestic price volatility for maize is generally higher than for rice and wheat in all three regions (Table 2; this is not true for Asia, but we only have maize price data for two Asian countries, China and the Philippines).

Table 2: Domestic price volatility by region by commodity (percent)

\begin{tabular}{lllll}
\hline & Africa & Asia & Latin America & All \\
\hline Rice & 7.0 & 4.3 & 4.1 & 5.1 \\
Wheat & 6.7 & 4.3 & 5.6 & 5.2 \\
Maize & 10.2 & 2.4 & 7.7 & 8.6 \\
\hline
\end{tabular}

Note: Price volatility is calculated as the standard deviation of $\ln \left(\mathrm{p}_{\mathrm{t}} / \mathrm{p}_{\mathrm{t}-1}\right)$, where $\mathrm{p}_{\mathrm{t}}$ is the real price at time t. Data used are monthly prices from January 2007 to December 2013. Averages reported in the table are simple averages across countries.

This finding is consistent with a visual impression of Figure 1, Figure 2, and Figure 3, where the maize price indices tend to show higher peaks and deeper troughs than those for rice and wheat. It is also consistent with FAO (2011) and Pierre et al (2013), which found that domestic rice and wheat prices in African countries were more stable than maize prices (as well as being more stable than prices of other staples such as cassava, sorghum and millet). Greater price volatility for domestic maize prices may be due to the fact that a lesser proportion of global maize production is irrigated (20 percent, compared with 62 percent for rice and 31 percent for wheat; Portmann et al, 2010). In addition to the smaller role of irrigation in maize production, domestic maize prices may be more prone to volatility (relative to rice and wheat) because of the very thin international market for white maize, which is the maize that dominates human consumption (the world rice market is also thin). This might lead to lack of connection between domestic and international markets, which lessens the potential for international maize markets to play a stabilizing role in domestic price formation. However, since white and yellow maize are substitutes (for farmers, if less so for consumers), the yellow maize international market might still be able to provide some stability to domestic prices in the event of domestic production shocks. The fact that large quantities of maize are used for biofuels might be another possible reason for greater domestic maize price volatility, although if this were a key driver one might expect that the mechanism would work primarily through more volatile world market maize prices and their linkages with oil prices. But world market maize prices are no more volatile than world market rice or wheat prices - the key difference is domestic price volatility. Thus, the reasons behind domestic maize price volatility need more investigation.

For all three commodities, price volatility in Africa is substantially higher than in Asia or Latin America (Table 2). Higher domestic price volatility in Africa may be due to the fact that African countries are often reliant on imports for a large share of domestic consumption, especially for rice and wheat. But greater exposure to international markets can also stabilize domestic prices (e.g. Rapsomanikis and Sarris, 2008): as noted above, domestic rice and wheat prices in Africa are more stable than domestic prices of other staple foods. Besides exposure to international markets, there are other key factors that are also responsible for differing degrees of price volatility in different contexts: exchange rate volatility, infrastructure, domestic production volatility and domestic policies (Pierre et al, 2013; Kornher and Kalkuhl, 2013). Africa has generally worse transportation and communication infrastructure, as well as 
greater domestic production volatility due to a lower proportion of irrigated land (Cassman and Grassini, 2013). Poor infrastructure may also heighten the impact of oil price increases when moving cereals internally or across international borders.

For a small selection of case studies (14, in eight different countries), data on both wholesale and retail prices were available in FAO (2014a) for the same quality and same location. In general, the percentage changes in the two measures (wholesale and retail) were similar. In eight cases, wholesale prices increased more (implying a narrowing of the wholesale-retail margin), while in the other six cases wholesale prices increased less (implying a widening of the margin). Thus, there was not any systematic substantial widening (or narrowing) of the wholesale-retail margin. This leaves aside the analysis of farm-wholesale margins, which are larger and more important to analyze. Unfortunately, the lack of farm price data precludes any systematic analysis of this question except in isolated cases, and is not discussed here.

\subsubsection{Price movements on domestic and world markets}

Comparison of the composite domestic cereal price indices (Figure 7, Figure 8, and Figure 9), both weighted and unweighted, with the world price index shows that domestic prices are generally more stable for rice, wheat and maize, especially rice and wheat. Indeed, the most striking impression from these graphs is that the peaks in world prices are much higher than the peaks in the domestic price indices.

For both rice and wheat, the simple average domestic volatility across all countries is 5 percent, compared with 8 percent for the volatility of world market prices (see the circled points in Figure 4, Figure 5, and Figure 6). Thus, world rice and wheat prices have volatility measures that are 56 and 58 percent higher than the average domestic volatility measure.

Maize, however, is different. Volatility is 7 percent for world maize prices, but the average domestic volatility is 9 percent, higher than for world markets. Maize is also different in that world prices returned to January - June 2007 levels rather quickly (reaching an index value of 97 in November 2008), but the domestic price index remained relatively high for a much longer duration - by October 2010, it had only declined to an index value of 106 , before turning up again in response to another world price shock. Thus, the duration of the shock to domestic prices was much longer than for world prices.

Comparing world price volatility across the three cereals shows that rice is intermediate between maize and wheat, but that volatility measures are similar for all three. Thus, while the world rice market is "thin" in that a relatively small percentage of total production enters international trade, it is not clear that the world rice market is more volatile than world maize and wheat markets. This could be due to offsetting factors such as the greater share of global rice production that is irrigated. And domestic rice prices are as stable, or more so, than domestic wheat and maize prices.

In terms of price levels in 2013 compared with the first half of 2007, Figure 4, Figure 5, and Figure 6 also show that the increases in world prices for rice, wheat and maize have been greater than for domestic prices for all but a handful of countries. Thus, while domestic prices have clearly increased since 2007 in most countries, it is also true that these price increases have been much less than those on world markets. Nevertheless, the observed increases in domestic prices are still substantial for the poor in many countries: e.g., a 20 percent increase in domestic prices for a family that spends 30 percent of its income on staple foods leads to a decline in real income of approximately 6 percent. 
Figure 7: Domestic price indices (weighted and unweighted) and world price index, rice.

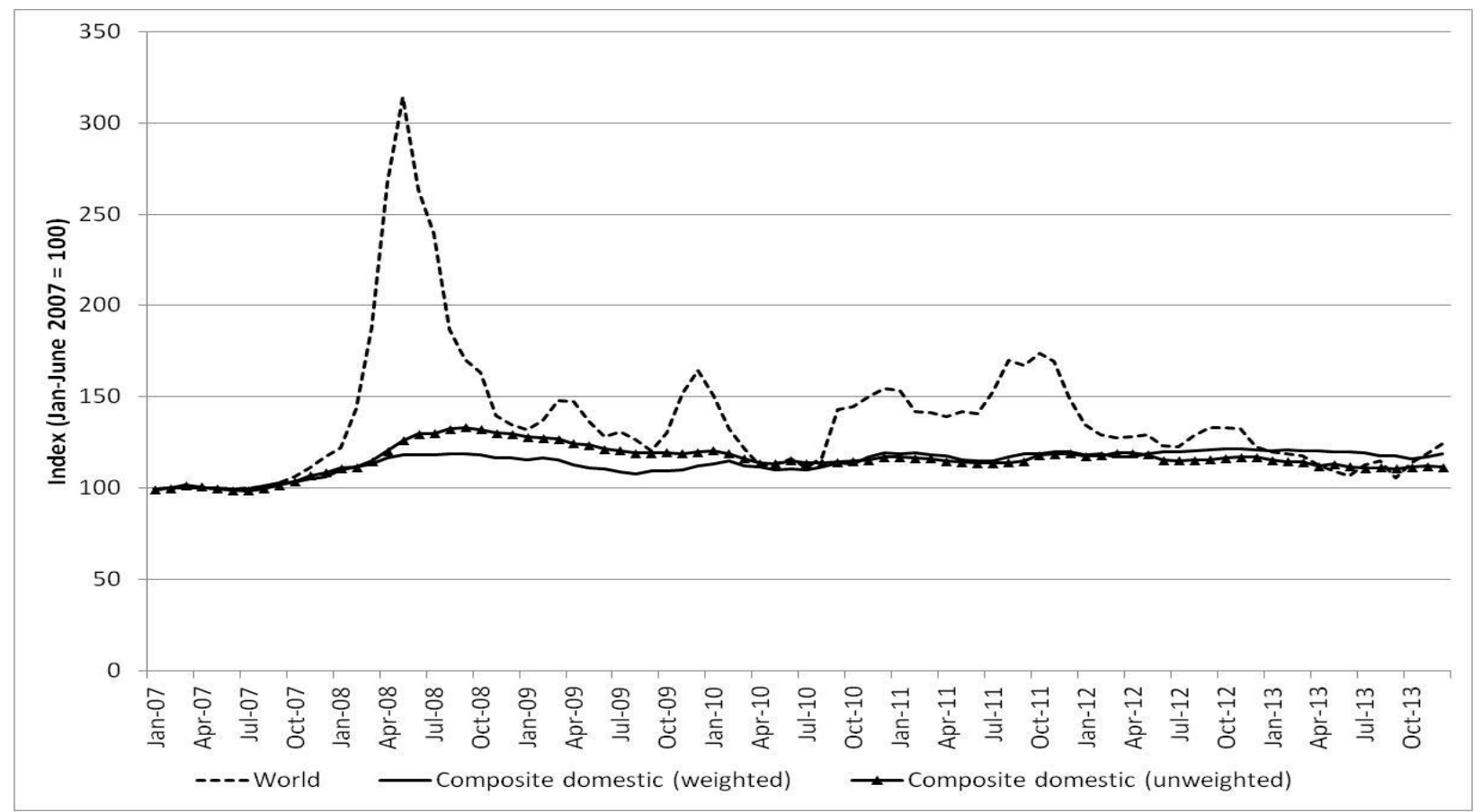

Figure 8: Domestic price indices (weighted and unweighted) and world price index, wheat.

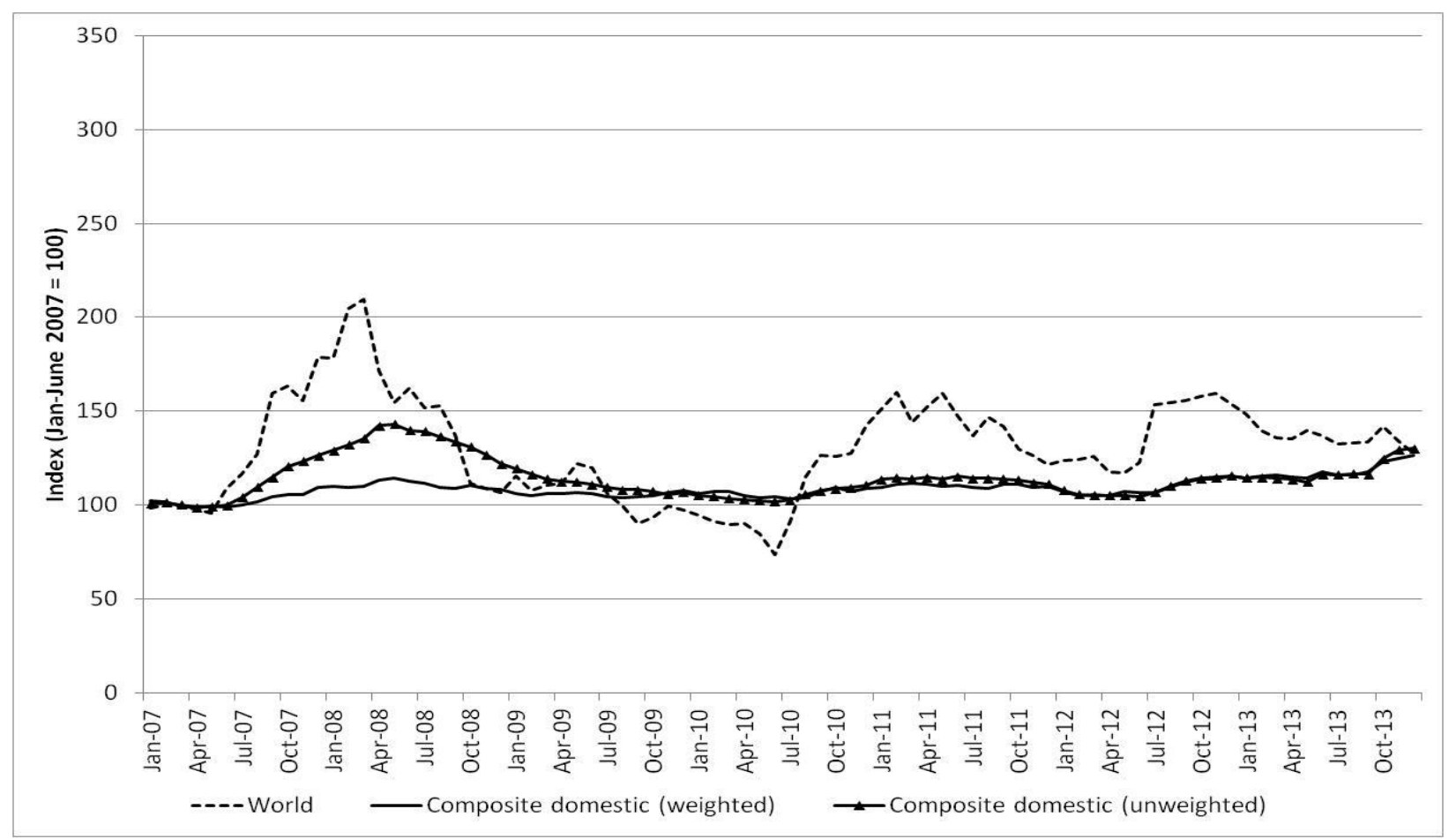


Figure 9: Domestic price indices (weighted and unweighted) and world price index, maize.

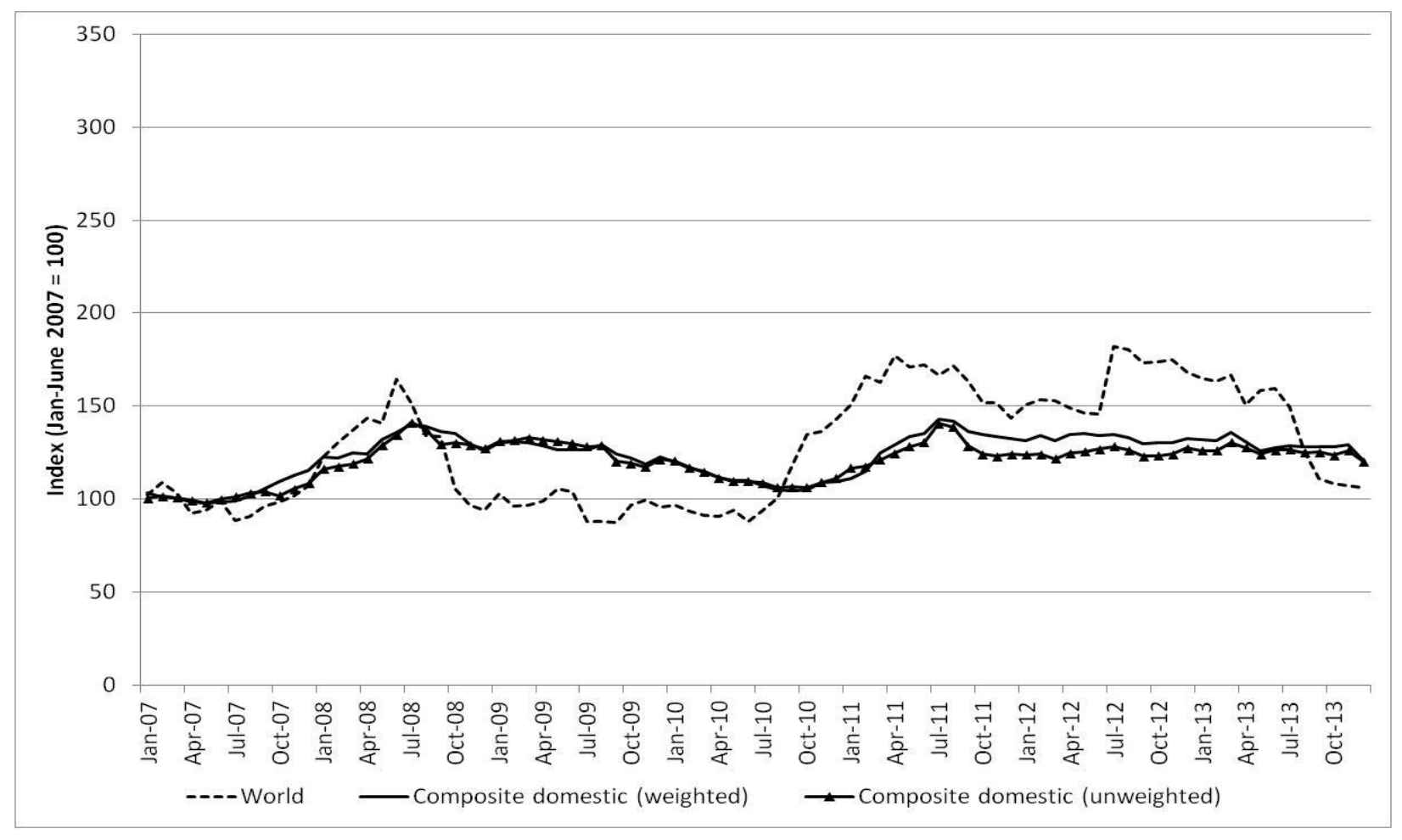

\subsubsection{Comparison with other food price indices}

The composite domestic food price indices presented above exhibit behaviour that is substantially different than for other food price indices (Figure 10). This is not surprising, given that they have different objectives and measure different concepts. For example, the FAO Food Price Index (FAO 2014d) measures changes in nominal world market prices, with different commodities weighted by their shares in the value of international trade. This weighting procedure gives high weights to meat and dairy products, which together account for more than half of the index. In addition, it measures changes in world market prices, not domestic prices.

The International Monetary Fund also calculates a food price index, and since 2007 it has behaved very similarly to the FAO food price index. There is also a version of the FAO Food Price Index that is deflated by the manufacturing unit value (MUV) index (World Bank 2014). This alternative index thus presents food price movements relative to the prices of manufactured goods (the MUV index excludes services, so it is not an index of general inflation). 
Figure 10: Comparison of rice, wheat and maize domestic price indices with other food price indices.

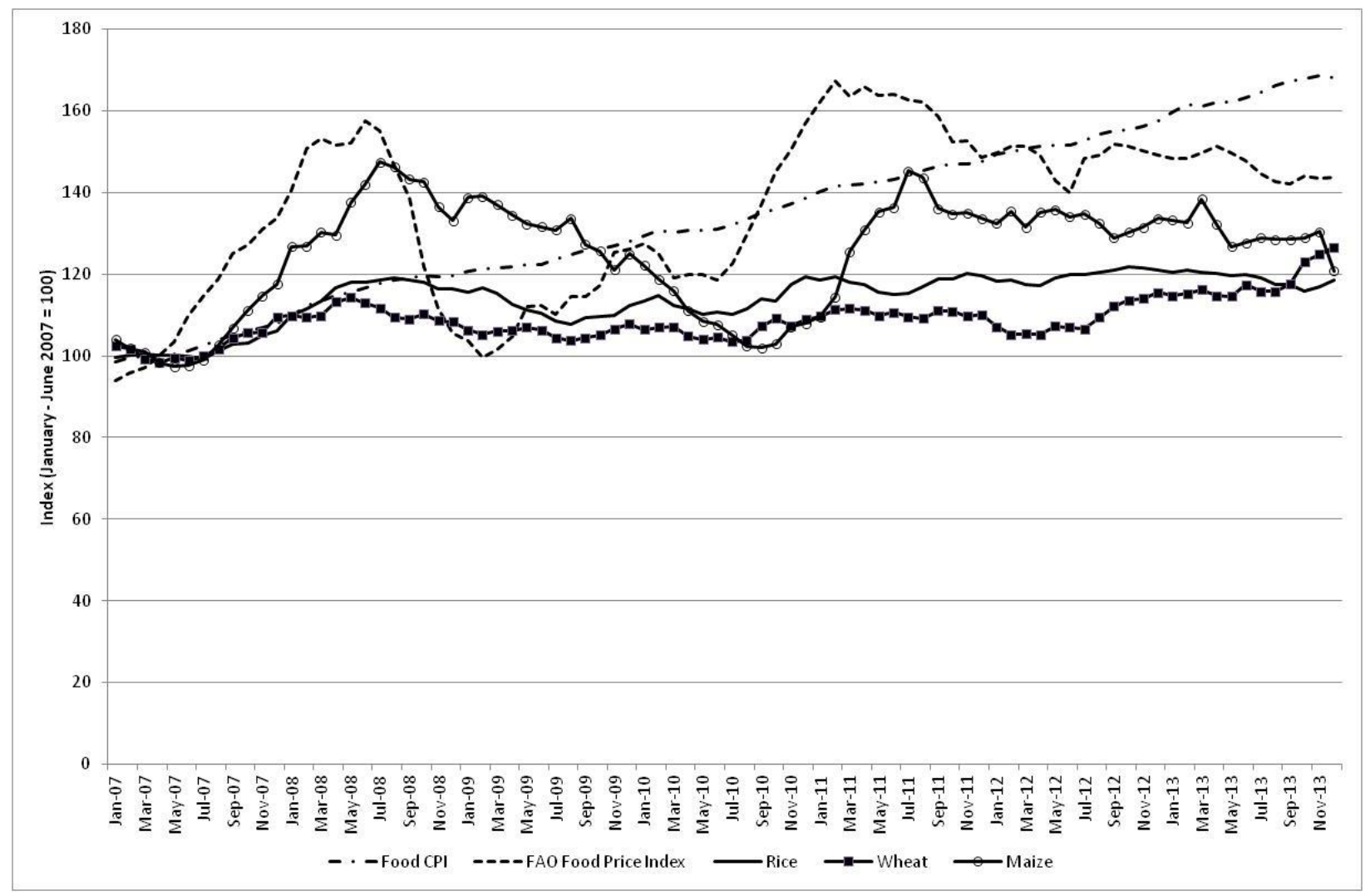

FAO also calculates a measure of global consumer food price inflation (FAO 2014e), which is a measure of changes in nominal domestic food prices, with different countries weighted by their share in global population. Within each country, different commodities are weighted by their share in total expenditures. This latter procedure gives higher weights to commodities that are relatively most important to the top half of the income distribution, since these are the people with most of the purchasing power and who account for most expenditures on food. This index also measures nominal prices, which tend to rise more or less continuously over long periods of time, as can be seen in Figure 10. Aggregate food price inflation is certainly important, but the weights used in constructing such measures do not reflect the expenditure patterns of the poor, which are more oriented towards staple foods. Thus, such an index may not be the most appropriate indicator for food security impacts, as it is the poor who lack access to food and are the most food insecure.

The several indices discussed in this section contrast with the rice, wheat and maize indices presented in this paper. The latter measure changes in real domestic market prices, with different countries weighted by their share in global direct food consumption of each cereal. The focus of our indices on the three main cereals means a more narrow coverage, but a coverage that focuses on the commodities of most importance to the poor - thus, these indicators are helpful for assessing global food security. 


\subsection{Summary and conclusion}

The "food price crisis" has typically been viewed as a general phenomenon and interpreted from a global standpoint (von Braun et al., 2008; Wright and Bobenrieth, 2009). However, its effects have varied across commodities, regions and countries. In order to explore this issue further, this paper calculates a new set of food price indices. The indices presented here differ from existing price indices in that they calculate prices after adjusting for inflation; they focus on domestic prices, which are the prices actually paid by consumers; and they focus on rice, wheat and maize, the three most important sources of dietary energy for the poor and food insecure in developing countries. Because of these differences, the evolution of these indices over time differ from existing indices of world market prices and domestic food price inflation.

The indices allow us to draw several conclusions. First, they show that domestic staple food prices were higher in 2013 than they were in the first half of 2007: weighted average real domestic rice, wheat and maize prices increased by 19, 19 and 29 percent, respectively. Second, they show that domestic prices have typically increased much less than world prices, and that domestic prices are less volatile than world prices (although maize is an exception to the latter point). This different behaviour of domestic prices is due to the impacts of policies, infrastructure and exchange rates, among other factors. Third, they show that domestic price indices broadly mirror the large world price spikes (i.e. price transmission elasticities in the face of large price shocks on world markets are positive in many but not all cases). Fourth, they show that domestic price changes have varied widely across countries, and that domestic price increases are not necessarily due to increases in world market prices. Finally, domestic maize prices are more volatile than domestic rice and wheat prices, and domestic cereal prices in Africa are more volatile than in Asia and Latin America. These conclusions underline the importance of country- and commodityspecific analysis.

The domestic price data analyzed here show that an era of higher food prices is currently upon us. To some extent, freely operating markets will bring forth additional private sector investment in response to the higher prices, but it is also important for the public sector (national governments and donors) to be aware of the higher prices and mimic market responses by increasing investment (especially in public goods such as agricultural research that may not be provided by the private sector in optimal amounts). The argument for additional investment is not necessarily an argument that higher prices increase poverty, but rather an argument about resource allocation - higher relative prices for staple foods indicate increasing scarcity and should therefore call forth additional investment in staple food production. This investment is likely needed in all countries to a greater or lesser degree, depending upon agro-ecological conditions. Higher relative prices for food could of course change rapidly, as commodity prices are volatile, but all investment is made in a context of uncertainty.

The data might suggest that the resource allocation case for investment is less strong than would be implied by using only data on world market prices, although such a conclusion is made slightly problematic by the fact that percentage changes in prices can be different at different levels of the marketing system (Dawe and Maltsoglou, 2014) - the percentage changes in farm prices might be higher than those reported here, and farm prices should be a better indicator of staple food scarcity than retail prices.

Thus, for future work, collection of farm price data is a key priority - farm prices do not necessarily track the wholesale and retail prices that are analyzed in this paper. Although it is not done here, partially due to a less extensive set of data, it would also be worthwhile to construct price indices for several less 
actively traded staple foods: for example, beans and potatoes in Latin America and cassava, sorghum and millet in Africa. 


\subsection{References}

Abdulai A. 2000. Spatial price transmission and asymmetry in the Ghanaian maize market. Journal of Development Economics, 63: 327-349.

Anderson, K. 2012. Government trade restrictions and international price volatility. Global Food Security, 1: 157-166.

Bakhshoodeh M. 2010. Impacts of world prices transmission to domestic rice markets in rural Iran. Food Policy, 35: 12-19.

Balcombe K, Bailey A, Brooks J. 2007. Threshold effects in price transmission: the case of Brazilian wheat, maize and soya prices. Amer. J. Agr. Econ., 89 (2): 308-323.

Baquedano FG, Liefert W, Shapouri S. 2011. World market integration for export and food crops in developing countries: a case study for Mali and Nicaragua. Agricultural Economics, 42: 619-630.

Baquedano FG, Liefert WM. 2014. Market integration and price transmission in consumer markets of developing countries. Food Policy 44: 103-114.

Barrett CB, Bellemare MF. 2011. Why food price volatility doesn't matter. Foreign Affairs. 12 July 2011.

Block S, Kiess L, Webb P, Kosen S, Moench-Pfanner R, Bloem MW, Timmer CP. 2004. Macro shocks and micro outcomes: child nutrition during Indonesia's crisis. Econ. Human Biol. 2(1):21-44.

Brinkhoff, Thomas. 2014. City Population. Available at: http://www.citypopulation.de.

Briones R, Galang I. 2014. The continuing saga of rice self-sufficiency in the Philippines. Philippine Institute for Development Studies Policy Notes No. 2014-08. Available at: http://www.pids.gov.ph/policynotes.php?id=5374\&pubyear=2014.

Burke WJ, Myers RJ. 2014. Spatial equilibrium and price transmission between Southern African maize markets connected by informal trade. Food Policy, 49: 59-70.

Cassman KG, Grassini P. 2013. Can there be a green revolution in Sub-Saharan Africa without large expansion of irrigated crop production? Global Food Security 2(3): 203-209.

Conforti P. (editor) 2011. Looking ahead in world food and agriculture: perspectives to 2050. Rome: Food and Agriculture Organization. 539 pp.

Conforti, P. 2004. Price transmission in selected agricultural markets. Commodity and Trade Policy Research Working Paper No 7. Rome: Food and Agriculture Organisation.

Cudjoe G, Breisinger C, Diao X. 2010. Local impacts of a global crisis: Food price transmission, consumer welfare and poverty in Ghana. Food Policy, 35: 294-302.

Dawe D. 2009. Cereal price transmission in several large Asian countries during the global food crisis. Asian Journal of Agriculture and Development, 6(1): 1-12.

Dawe D, Block S, Gulati A, Huang J, Ito S. 2010. "Domestic rice price, trade and marketing policies," Chapter 3.2 in Rice in the Global Economy: Strategic Research and Policy Issues for Food Security. Pandey $S$ et al, eds., International Rice Research Institute.

Dawe D \& Maltsoglou M. 2014. Marketing margins and the welfare analysis of food price shocks. Food Policy 46: 50-55. http://dx.doi.org/10.1016/i.foodpol.2013.12.010.

de Brauw A. 2011. Migration and child development during the food price crisis in El Salvador. Food Policy, 36(1): 28-40.

de Gorter H, Drabik D, Just DR. 2013. How biofuels policies affect the level of grains and oilseeds prices: theory, models and evidence. Global Food Security.

de Janvry A, Sadoulet E. 2010. The global food crisis and Guatemala: What crisis and for whom? World Development, 38 (9): 1328-1339.

Dorosh P. 2009. Price stabilization, international trade and national cereal stocks: world price shocks and policy response in South Asia. Food Security 1:137-149.

Dorward A. 2011. Getting Real about Food Prices. Development Policy Review 29(6): 647-664. 
Dorward A. 2012. The short- and medium- term impacts of rises in staple food prices. Food Security 4: 633-645.

Dupont A, Thirlwell M. 2009. A New Era of Food Insecurity? Survival: Global Politics and Strategy 51 (3): 71-98.

Fang, C. 2010. How China stabilized grain prices during the global price crisis. In: Dawe, D., ed. The rice crisis: markets, policies and food security. London and Washington, DC, FAO and Earthscan, pp. 255-272.

FAO (Food and Agriculture Organization). 2011. State of Food Insecurity in the World. Rome. Available at: http://www.fao.org/publications/sofi/2011/en/.

FAO (Food and Agriculture Organization). 2014a. GIEWS Food Price Data and Analysis Tool. Available at: http://www.fao.org/giews/pricetool/.

FAO (Food and Agriculture Organization). 2014b. FAOStat online database. Available at: http://faostat.fao.org/.

FAO (Food and Agriculture Organization). 2014c. Monitoring and Analysing Food and Agricultural Policies. Available at: http://www.fao.org/mafap/home/en/.

FAO (Food and Agriculture Organization). 2014d. FAO Food Price Index. Available at: http://www.fao.org/worldfoodsituation/foodpricesindex/en/.

FAO (Food and Agriculture Organization). 2014e. FAO Global and regional consumer food inflation monitoring. Available at: http://www.fao.org/economic/ess/ess-economic/cpi/en/\#.U-HRkOSw40.

Gale F. 2013. Growth and Evolution in China's Agricultural Support Policies. Economic Research Report Number 153. United States Department of Agriculture Economic Research Service. Available at: http://www.ers.usda.gov/media/1156829/err153.pdf.

Gulati, A. \& Dutta, M. 2010. Rice policies in India in the context of the global rice price spike. In: Dawe, D., ed., The rice crisis: markets, policies and food security. London and Washington, DC, FAO and Earthscan, pp. 273-295.

Hassouneh I, von Cramon-Taubadel S, Serra T, Gil JM. 2012. Recent Developments in the Econometric Analysis of Price Transmission. Working Paper No. 2, Transparency of Food Pricing (TRANSFOP). $\begin{array}{llll}\text { Accessed } & 23 & \text { December } & 2014\end{array}$ http://www.transfop.eu/media/universityofexeter/businessschool/documents/centres/transfop recent developments in economtric pt.pdf.

Headey D. 2014. Food Prices and Poverty Reduction in the Long Run. IFPRI Discussion Paper 01331. International Food Policy Research Institute, Washington DC.

IMF (International Monetary Fund). 2014. International Financial Statistics online database. Available at: http://elibrary-data.imf.org/.

Irwin SH, Good DL. 2009. Market Instability in a New Era of Corn, Soybean, and Wheat Prices. Choices 24(1): 6-11.

Ivanic, M., Martin, W., Zaman, H., 2011. Estimating the Short-Run Poverty Impacts of the 2010-11 Surge in Food Prices. World Bank Policy Research Working Paper 5633, World Bank, Washington, DC.

Kornher, L. \& Kalkuhl, M. 2013. Food price volatility in developing countries and its determinants. $53^{\text {rd }}$ Annual Conference of the German Association of Agricultural Economists. Berlin, Germany, September 25-27.

Minot N. 2010. Transmission of World Food Price Changes to Markets in Sub-Saharan Africa. Available at: http://www.ifpri.org/sites/default/files/Minot 2010.pdf.

Naylor, R. L. \& Falcon, W. P. 2010. Food Security in an Era of Economic Volatility. Population and Development Review, 36: 693-723. doi: 10.1111/j.1728- 4457.2010.00354.x

OECD and FAO. 2014. OECD-FAO Agricultural Outlook 2014, OECD Publishing. http://dx.doi.org/10.1787/agr outlook-2014-en. 
Pierre, G., Morales-Opazo, C., Demeke, M. 2014. Analysis and determinants of retail and wholesale staple food price volatility in developing countries. Scientific Paper 3, ULYSSES project, EU 7th Framework Programme, Project 312182 KBBE.2012.1.4-05. Available at: http://www.fp7ulysses.eu/publications.html.

Portmann FT, Siebert S, Döll P. 2010. MIRCA2000-global monthly irrigated and rainfed crop areas around the year 2000: a new high-resolution data set for agricultural and hydrological modeling. Global Biogeochem. Cycles 24, GB1011. doi:10.1029/2008GB003435.

Rapsomanikis, G. 2011. Price Transmission and Volatility Spillovers in Food Markets of Developing Countries. In: Methods to Analyse Agricultural Commodity Price Volatility, ed. I. Piot-Lepetit \& R. M'Barek (Springer New York), pp. 165-179.

Rapsomanikis G, Sarris A. 2008. Market integration and uncertainty: the impact of domestic and international commodity price variability on rural household income and welfare in Ghana and Peru. Journal of Development Studies, 44(9): 1354-1381.

Regmi A, Meade B. 2013. Demand Side Drivers of Global Food Security. Global Food Security 2(3): 166171.

Robles, M., Torero, M., 2010. Understanding the impact of high food prices in Latin America. Economia 10 (2), 117-164.

Saifullah, A. 2010. Indonesia's rice policy and price stabilization programme: managing domestic prices during the 2008 crisis. In: Dawe, D., ed., The rice crisis: markets, policies and food security. London and Washington, DC, FAO and Earthscan, pp. 109-122.

Short, C., Barreiro-Hurle, J., Balie, J. 2014. Policy or Markets? An Analysis of Price Incentives and Disincentives for Rice and Cotton in Selected African Countries. Canadian Journal of Agricultural Economics. pp. 1-29.

Timmer, CP. 1993. Rural Bias in the East and Southeast Asian Rice Economy: Indonesia in Comparative Perspective," Journal of Development Studies. 29 (4): 149-76.

Torlesse H, Kiess L, Bloem MW. 2003. Association of household rice expenditure with child nutritional status indicates a role for macroeconomic food policy in combating malnutrition. J. Nutr. 133(5):1320-1325.

Tyner W. 2013. Biofuels and food prices: separating wheat from chaff. Global Food Security.

Von Braun, J., Ahmed, A., Okyere, K.A., Fan, S., Gulati, A., Hoddinott, J., Pandya-Lorch, R., Rosegrant, M.W., Ruel, M., Torero, M., van Rheenen, T., von Grebmer, K. 2008. High food prices: The what, who, and how of proposed policy actions. Policy Brief, May. Washington, DC: International Food Policy Research Institute. Available online: http://www.ifpri.org/sites/default/files/publications/foodpricespolicyaction.pdf.

World Bank. 2014. Manufactures Unit Value Index (MUV). Available at: http://data.worldbank.org/datacatalog/MUV-index.

Wright, B. \& Bobenrieth, E. 2009. The Food Price Crisis of 2007/2008: Evidence and Implications. In: FAOFood Outlook/Global Market Analysis, pp. 59-65. December. Available at: http://www.fao.org/GIEWS/English/fo/index.htm. 


\section{Policy or Markets? An Analysis of Price Incentives and Disincentives for Rice and Cotton in Selected African Countries ${ }^{9}$}

\subsection{Introduction}

In the three decades beginning in 1950, developing countries in Africa generally followed Prebish's (1950) and Hirschman's (1958) import substitution industrialization development paradigm, together with extensive intervention in the agricultural sector in the form of price and movement controls and parastatal monopolies responsible for processing and marketing of most agricultural commodities (Kherallah et al., 2000). This was followed in the 1980s and 1990s by a deregulation agenda aligned with the Washington consensus. ${ }^{10}$ For agriculture, this lead to deregulation, market liberalization, and the elimination or restructuring of parastatals, restricting their role to such things as providing market information, maintaining food security stocks, etc. However, these various policies generally failed to deliver a number of their objectives (Williamson, 2000; Williamson, 2002; Stiglitz, 2002; Rodrik, 2006) and, in particular, did not result in the expected higher incomes for farm families, increased agricultural productivity and production in Africa which remains far below its potential (Byerlee et al., 2013). In more recent years, there has been considerable reversion, in some countries, a greater role to the government in agriculture (Kherallah et al., 2000).

Governments in Africa have intervened extensively in the agricultural sector for both political and economic reasons. ${ }^{11}$ The most common justification for government intervention in developing countries is the need to spur economic development and enhance food security. ${ }^{12}$ The need to enhance food security and to protect consumers by assuring adequate supplies at affordable prices is commonly stated an objective of policies for cereals and other basic food commodities. The goals of protecting poor farmers from excessive market power by traders and processors, and a need to provide substitutes for missing markets (for credit and other agricultural inputs, and transportation and processing services) are also described as policy objectives. ${ }^{13}$ Sometimes the usual public functions related to provision of infrastructure, research, market standards and information, and enforcement of phytosanitary standards are used as a rationale, especially in the context of a parastatal with a mandate to support a specific commodity.

\footnotetext{
${ }^{9}$ This essay is product of a joint effort with two FAO colleagues Cameron Short and Jesus Barreiro-Hurle. It was published in December 2014 in the Canadian Journal of Agricultural Economics, special issue, page 1-29.

${ }^{10}$ The Washington Consensus, promoted by the International Monetary Fund (IMF), the World Bank, and the US Treasury Department, advocated for a restricted role for government and a much more market-oriented incentive system. It refers to a set of ten relatively specific economic policy prescriptions encompassing macroeconomic stabilization, economic opening with respect to both trade and investment, and the expansion of market forces within the domestic economy (Williamson, 1989).

${ }^{11}$ Lele and Christiansen (1989) describe the political objectives and constraints for agricultural policy in Africa.

${ }^{12}$ For example, the main policy objective for rice given in the Ghana National Rice Development Strategy (NRDS) is to "contribute to food security...increase income and reduce poverty" (Ghana Ministry of Agriculture, 2009). These same objectives, expressed in slightly different terms, can be found in the NRDS of all countries considered in this paper. See the Coalition for African Rice Development (CARD) website: http://www.riceforafrica.org. ${ }^{13}$ Akiyama et al. (2003) maintain that protecting farmers and consumers were the stated objectives of the control over marketing of agricultural products. They also describe the problem of missing markets for farm inputs following market liberalization as does Kherallah et al. (2000). Lele and Christiansen (1989) emphasize how the absence of a credit market for small scale farmers in Africa has inhibited the development of markets for other purchased inputs.
} 
Food insecurity can be the result of both policy and market failures. Food insecurity takes many different forms in Africa today, from isolated individuals and families with chronic inadequate access to food and nutrition, to sporadic regional shortages caused by drought and other similar events to large-scale famines. Households in many sub-Saharan countries and regions within them are normally self-sufficient in traditional staple food crops resulting in thin marketing structures. These market structures are incapable of providing fast and efficient response to shortages resulting in price spikes, severe shortages in both urban and rural areas, malnutrition and worse. ${ }^{14}$ Although food is a private good, we argue that food security is a public good..$^{15}$ Policy objectives for food security are often expressed in terms of increased production or self-sufficiency of the staple crops, despite economic advice that self-sufficiency may be costly and not contribute meaningfully to the objective of improving food security (Sturgess, 2008).

Clearly distributional inequity is also a rationale for policies to increase food security as its impact is greatest on poor net food buyers. The objective of protecting small farmers from excessive market power by traders and processors also has a distributional equity dimension as well as a response to scale economies in processing and marketing in local African markets. Missing markets for credit and other inputs are likely related to the difficulty of enforcing repayment which has been a justification in the past for the parastatal monopsonies that can recover these costs in the payments for the farmers' produce. ${ }^{1617}$

The problem of developing policy measures to mediate market failures poses difficulties that challenge the most sophisticated governments in developed countries: governments may not be able to accurately estimate costs to regulate prices in a market where one or more agent has excessive market power or evaluate the true value of an externality or public good..$^{18}$ There may be several different objectives and policies affecting a commodity, group of commodities or factors of production leading to policy dissonance. Policy dissonance or lack of policy coherence is generally the result of inconsistency between the objectives pursued by a government (higher commodity prices for farmers and lower food prices for consumers, for instance) and the set of policy instruments used to achieve them (a share of public resources allocated to develop irrigation schemes, adoption of a floor price for rice producers, removal/decrease or adoption/increase of a the tariff on rice imports, etc.) that are sometimes conflicting and may result in sub optimal or even adverse impacts (Angelucci et al., 2013). In most markets, prices

\footnotetext{
${ }^{14}$ For instance, the Kenya maize supply was down by over a third following the long rains in June 2008 because civil unrest following the election in December 2007 and drought. [See the timeline in the report by the Africa Centre for Open Governance (2009). It wasn't until March 2009 that large imports of maize began to fill the gap. See Tangermann (2011) on the need for emergency stocks in this type of situation.

${ }^{15}$ According to the UK Department for Environment, Food and Rural Affairs (2009), the "common elements of definitions of food security are availability, access, affordability, safety and resilience." These elements of food security are similar to the elements that would go into definitions of personal security, security of personal property and well-functioning market that are part of the non-rival benefits of good governance. The concept of food security as a public good here is different from its discussion in the context of multifunctionality (where it is described as joint product of agricultural production) and recent efforts to promote food security as a "global public good."

16 The important role of information asymmetries in credit market failures has been demonstrated in a large number of articles summarized in Stiglitz (2001).

17 This is also a justification for awarding monopsony status to private sector firms that supply credit and other inputs as is the case for cotton ginneries in Mozambique.

${ }^{18}$ See Boadway (1979) p. 32 on the problem of valuing public goods for the government decision-maker and p. 37 on the problem of setting prices when there are increasing returns to scale. According to Wolf (1979), "(nonmarket) outputs are usually hard to define in principle, ill-defined in practice, and extremely difficult to measure independently of the inputs which produce them."
} 
and costs are continuously changing but most policies or policy instruments, such as regulated prices, are rarely changed more than once per year. Moreover, prices when administered are sometimes set following perverse incentives as identified by Wolf (1979).

Many of these issues are more acute for governments in developing countries. In many developing countries, the quality and quantity of agricultural statistics are low and, in the last decades, have undergone a serious decline compared to the average situation in industrialized countries (World Bank et al., 2011; FAO et al., 2012, Carfagna et al., 2013; Carletto et al., 2014; Morten, 2014). As recently pointed out by Annan (2013) and Wiggins and Leturque (2010), African governments have fewer resources for policy analysis and implementation which may result in what Wolf (1979) defines as non-market failure. While it cannot be expected that better statistics or strengthened capacities of the administration will eliminate non-market failures, the problem is generally aggravated by lack of reliable information and low staff capacities. The recurrent budget problem, for example, has been cited as reason for the failure to maintain roads and provide extension services to farmers. Equally important is that policy may be obstructed by the agents intended to implement it. This is a typical principal/agent problem, or "internality and private goods" non-market failure in the terms of Wolf (1979) that can be illustrated by institutional issues in the policy formulation-implementation-evaluation cycle (Benson, 2004; Bardham, 2005). For instance, the Kenyan government initially imported maize in late 2008 to reduce the impact of the large shortfall in the maize supply at that time noted above. This non-market action did not solve the issue of high prices as imported maize was sold to insiders at favourable prices who, in turn, captured many of the benefits. ${ }^{19}$ This is a case of the distributional inequity problem, the fourth category of nonmarket failure described by Wolf (1979). Collusion between government and private agents is not exceptional in Sub Saharan African countries: Botswana was the only African country in the top 50 of the 177 countries in Transparency International's Corruption Perceptions Index in which countries ranked lower are considered less corrupt. Most African countries rank above 100 (Transparency International, 2012). Poor infrastructure increases transaction costs but these are further exacerbated by the frequent police checks which provide opportunities for bribes and rents for those powerful enough to avoid this type of harassment.

The original analysis for each country was undertaken by the Monitoring and Analysing Food and Agricultural Policies (MAFAP) programme of the Food and Agriculture Organization (FAO) and partners. MAFAP is working with national governments and other country partners to set up a sustainable and country owned system for monitoring, analysing and eventually reforming food and agricultural policies. As part of this programme, MAFAP has estimated nominal rates of protection (NRPs) for key agricultural commodities over time to measure the impact of policies as well as market and non-market failures ${ }^{20}$ on wholesale prices in major markets where domestically produced commodities compete with imports and on the prices received by farmers. ${ }^{21}$ The NRPs estimated build on the well-established method, notably by the OECD, for measuring market price support by comparing the observed international and domestic prices. The NRPs are intended to help policy makers and donors understand if policies are having a positive impact, to compare results across countries and over time and to focus on where changes could be made to reduce distortions resulting from both non-market and market failures. By referring to the NRP, policy

\footnotetext{
${ }^{19}$ See Fengler and Kiringai (2009) and Africa Centre for Open Governance (2009) for details.

${ }^{20}$ Policy distortion is the impact of policy on prices, both the non-market failure component as well as the intended impact. Both market and non-market failures are not disaggregated at this time.

${ }^{21}$ MAFAP is working on a market development gap (MDG) indicator to disentangle the explicit policy effects from excessive transportation and processing costs, obsolete technologies and bribes in the value chains. It has also produced estimates of public expenditure for agriculture similar to the OECD's estimates of PSEs. These do not include market price support but the NRPs are intended as an indicator of the impact of this class of policies.
} 
makers and their development partners can discern if the policies implemented, in particular trade and marketing policies, are achieving the intended objective, for example, in terms of protection of the domestic production. We report on estimates of NRPs for two representative commodities, rice and cotton, in nine African countries over the period 2005-2010.

The next section presents the policy and market environment for the two commodities in the countries studied. We then provide a short summary of how NRPs are estimated and how the MAFAP method compares with some similar analyses found in the literature. The fourth section provides the results of the analysis while the final section provides a summary of the findings and some brief concluding comments.

\subsection{Policy context}

\subsubsection{General Context and Policy for Cotton ${ }^{22}$}

Cotton is mainly produced in the arid and semi-arid regions of Africa, where it is currently one of the most viable cash crops despite the negative effect of subsidies and high levels of protection of many of the OECD countries on world prices (Baffes et al., 2009; de Gorter, 2012). In 2010, cotton was by far the most valuable export crop in Burkina Faso and Mali, third most important and only slightly behind coffee and tobacco in Tanzania, fourth in Mozambique and Malawi, and seventh in Uganda. Better policies and targeted public investments could help increase cotton productivity and production resulting in higher competitiveness of the cotton value chain. Additional export opportunities could play an important role as a source of income and income diversification contributing to poverty reduction in these areas. It could also support the development of an African textile industry, in Kenya for example, to further integrate the economies of the East Africa Community (EAC), for instance. ${ }^{23}$

In each country analysed, only a small number of companies, public or private, operate ginneries, each of which deals with hundreds if not thousands of small-scale farmers. Lele and Christiansen (1989) describe how parastatals were used to benefit colonial trading companies in West Africa and expatriate settlers in East Africa before independence. They add that political objectives after independence were further complicated by the unwillingness of African governments of the time to allow non-indigenous groups and relatively dominant local ethnic groups to "achieve a prominent position in politically sensitive or economically powerful arenas."

In addition to the political motivations, there were a number of economic arguments that favoured parastatal monopsonies. These provided a means of implementing the conventional development paradigm favouring taxing agriculture. Small scale African farmers were said to lack access to information, credit, and other inputs (Toulmin and Guèye, 2003; FAO, 2005). Parastatals monopsonies took on the

\footnotetext{
22 This section is based on papers on Uganda by Ahmed and Ojangole (2012); Mali by Balié (2012); Mozambique by Dias (2012); Burkina Faso by Guissou and Ilboudo (2012a); Malawi by Derlagen (2013); and Tanzania by Mwinuka and Maro (2013). See http://www.fao.org/mafap/products/country-reports-technical-notes/en/.

${ }^{23}$ Kenya signed preferential trade agreement with the U.S. in 2000 under the latter's African Growth Opportunity Act, eliminating all duties and quotas on Kenyan textile exports to the U.S. Both textile exports and cotton lint imports from Uganda and Tanzania initially grew rapidly but peaked in 2004 constrained by the supply of cotton lint.
} 
function of providing these with the certainty that they could deduct the costs out of the proceeds of crop sales. (Bates, 1981; Tschirley et al., 2009; Tschirley et al., 2010).

There was, too, a perception that if government were not taxing agriculture, then others would:

"The stated objectives of the control over marketing were to protect farmers and consumers from exploitation by merchants and middlemen, reduce price fluctuations, and ensure tax and foreign exchange revenues... Sometimes state ownership was viewed as a way of protecting farmers from the local monopolies of privately owned processing facilities." (Akiyama et al., 2003, pg. 4)

This perception applies particularly to cotton processing and trading and is a rationale for policy in the period under consideration. The Malawi Ministry of Agriculture (2006, pg. 3) complains that the cotton ginning "companies instead of competing to buy seed cotton...collude and in the process offer low farm gate prices." Such a view is not surprising as there are only two cotton ginning companies in Malawi and about 120,000 cotton farmers, some of which are in the poorest regions of the country. There are many more ginneries in Tanzania but, according to Baffes (2002, pg.8), traders "in remote areas, especially in the eastern cotton growing area, are paid very little for cotton, in part because farmers were unaware of market prices and in part because of high transport costs." Of course, the ginneries must offer a price high enough to provide an incentive for continued cotton production but low enough for the ginnery to be able to sell its cotton at a profit while deterring competition from new ginneries.

This perception that there are pervasive increasing returns and missing markets for inputs affecting agricultural commodities in Africa has provided a rationale for government intervention. In short, these are the same types of concern which resulted in the explosion of marketing boards in Canada between 1930 and 1970. Some economists have been critical of this type of rationale for the creation of producer run cartels in Canada and regulation to protect farmers such as regulated freight rates for grain, barriers to imports and single desk commodity buyers. Secondly, it is increasingly the case that governments are backing away from support for these measures. In part, this change in heart may have been fuelled by the realization that the claims of market failures made in the past may have been exaggerated or, mistaken. Alternatively, it may be that (information, communication, and transportation) technology and market structure (fewer farmers operating large commercial farms) have changed making these policies unnecessary. As in Canada, the consolidation of small-scale farms into fewer, large-scale, commercial family businesses and the development of modern transportation and communications systems could eliminate many market failures. Jensen (2007) describes how the cell phone is already making a difference for market information deficiencies in developing countries.

All six countries studied have one or more agencies or parastatal organizations charged with promoting the cotton sector, but the degree of centralized direction exercised varies considerably from country to country. The private sector is now responsible for cotton ginning in all of the countries studied except for Mali and Burkina Faso where responsibility for cotton marketing is still vested in parastatals. Governments of both countries have set up regional companies that provide inputs to, and collect seed cotton from village level producer associations, process it in their ginneries and market the cotton lint, cottonseed and other by-products of the ginneries. They also play an important role in setting producer prices for seed cotton. However, in all countries studied ginneries operate well below capacity.

The two companies in Burkina Faso are owned by a consortium of domestic and international agribusiness companies including Reinhart (Swiss), Cargill (US), Dagris/Geocoton (French), and Ivoire Coton (Côte d'Ivoire) as well as I'Union nationale des producteurs de coton du Burkina (UNPC-B). The latter is an umbrella organization for the 12,250 cotton producer associations. There are two companies in Mali, but 
the Compagnie Malienne pour le Development des Textiles (CMDT) manages about 94 percent of the cotton produced. CMDT is almost entirely government-owned. In both countries, the companies operate in specific regions with an effective monopsony status.

The industry is only slightly less concentrated in Mozambique. The Mozambique Cotton Institute (IAM) is the main cotton parastatal with responsibilities for the production of seed cotton, protection of stakeholders and fostering the development of the industry. It licenses eight ginneries which each have exclusive concessions to buy seed cotton in a specific region, fixes minimum pan-seasonal and panterritorial prices and is the buyer of last resort if the ginneries are not willing to buy seed cotton from some producers.

The cotton value chains in the other three countries are far more market-oriented. The Tanzania Cotton Board (TCB) is primarily a regulatory agency that promotes the development of the cotton sector through setting quality standards, licensing post-farm gate businesses involved in cotton trade and processing, farmer education and ensuring the seed cotton market is competitive. There are about 500,000 cotton farmers in Tanzania who sell their seed cotton to cotton traders or directly to one of the 40 to 60 ginneries. Since 2007, a new contract farming system has been made available in Tanzania in which farmers can get credit and other inputs from a ginnery and agree to sell their seed cotton to the ginnery according to the terms of the contract. The TCB also operates a network of about 8,000 'buying posts' for farmers not selling their seed cotton under contract.

The Ugandan cotton sector is organized much like that in Tanzania. Ginneries in Uganda are privately owned and operated companies that market the cotton lint and cottonseed they produce. The Government of Uganda mandated the Cotton Development Organization (CDO) to promote, monitor and regulate. The ginneries in Uganda are also required to provide a certain amount of cotton seed to the CDO which in turn provides good quality, treated seed to cotton farmers without charge.

Malawi's Cotton Development Trust (CDT) brings together all stakeholders in the value chain: farmers, input suppliers, ginners and the Malawi Ministry of Agriculture and Food Security. It recommends a minimum price for seed cotton each year to the government and advises on other aspects of policy for the cotton value chain.

In all cases, ginnery costs are adjusted for the value of cotton seed produced and sold. In addition, there are some significant differences in what is included in the price at various points along the value chain and more particularly in terms of costs directly or indirectly supported by cotton growers. Where ginneries supply farm level inputs (seeds, fertilizers, pesticides and extension services) reported farm prices appear to be net of these input costs and as a result farm gate prices are lower than they would be if farmers bore these costs directly. Individual farmers and farmer associations store their seed cotton in their own silos in some of the countries studied (e.g. Tanzania). Farmers bear some or all transport costs in some countries (e.g. Uganda). In others, ginneries are responsible for transportation costs giving them more control over supply logistics (e.g. Mali and Mozambique). These differences affect the overall transport and storage costs, including opportunity costs, in the value chain and can explain some price differences at the farm gate although they result in relatively smaller differences in the nominal rates of protection.

All countries studied have a complex policy framework for the cotton value chain as summarized in Table 3. At the beginning of the crop year, all of the governments concerned publish administrative prices that are variously described as minimum, floor, forecast or indicative prices. In Mozambique and Mali, a final farm price is announced near harvest based upon prices that are likely to be realized from the sale of cotton lint available minus an estimate of market access costs. An administrative price determined later in the season is likely to be a better estimate of the competitive price but can still be distorted and difficult 
to implement. When the minimum price has been set higher than what the ginners believe they can pay, governments may provide subsidies. For example, Mozambique has had to enforce its minimum price on at least one occasion since 2007 by buying seed cotton that ginneries were unwilling to purchase. The Instituto de Algodão de Moçambique (IAM) bought the unwanted cotton and presumably sold it at a loss.

Table 3: Policy measures employed regarding cotton value chains in the countries included in the study (2005-2010)

\begin{tabular}{lllllll}
\hline & $\begin{array}{l}\text { Input } \\
\text { Subsidies }\end{array}$ & $\begin{array}{l}\text { Regional } \\
\text { Monopsony }\end{array}$ & $\begin{array}{l}\text { Administered } \\
\text { Price }\end{array}$ & $\begin{array}{l}\text { Price } \\
\text { Support }\end{array}$ & Export Levy & $\begin{array}{l}\text { Exchange } \\
\text { Rate }\end{array}$ \\
\hline Burkina Faso & $2005-10$ & $2005-10$ & $2005-10$ & $2005-10$ & & $2005-10$ \\
Malawi & $2007-08$ & & $2005-10$ & & $2008-10$ \\
Mali & $2009-10$ & $2005-10$ & $2005-10$ & & $2005-10$ & \\
Mozambique & $2005-10$ & $2005-10$ & $2005-10$ & & $2005-10$ & \\
Uganda & $2005-10$ & & $2005-10$ & 2008 & & \\
Tanzania & 2008 & & $2005-10$ & 2010 & & \\
\hline
\end{tabular}

Source: authors based on MAFAP information

In Burkina Faso, the government and l'Agence Française du Développement has endowed a fund to subsidize farmers when realized prices at harvest are below the minimum price. The fund pays the difference between the realized price and the minimum. If global prices at harvest are above the minimum price, farmers in Burkina Faso receive an administratively determined premium with part of the extra revenue over 5 percent of the minimum going to the fund to support prices in other years that would be below the minimum.

In Malawi, the government sets a "minimum price" that seems to function merely as a forecast. Prices paid to farmers by the two ginning companies in 2008 and 2010 were 63 percent and 46 percent higher than the minimum price respectively, but in 2009 , they were 44 percent lower than the minimum price.

In some countries, there is a tendency for the minimum price to become the final price. According to the Uganda Ministry of Agriculture, their indicative price was also the final price in all but three of the last 17 years while Baffes (2002) and Baffes et al. (2008) report that in some cases traders in Tanzania collude to avoid paying more than the minimum price and in others farmers resist prices below the minimum.

Except for Burkina Faso, the method for responding to prices below the administrative price appears to be more or less ad hoc. The willingness and ability of governments to support a minimum price clearly depends on the situation. Uganda provided price subsidies in 2007/2008 and Tanzania for the 2009/10 crop year. In Uganda's case, the realized seed cotton price was 50 percent below the minimum without the subsidy but the subsidy brought it up to 75 percent of the minimum. The subsidy amounted to 17 percent of the realized price in Tanzania's case. In general, governments find it difficult administratively to finance expenditures that are not foreseen in the national budgeting process. Large outlays may ultimately need to be accommodated by reduced expenditures elsewhere. The use of terms such as "indicative" and "reference" by countries of the East Africa Community (EAC) as well as minimum also suggests that minimum prices are something less than a guarantee. 
In summary, the government plays a major role in the cotton sector of the countries studied. Policy appears to be most market-oriented in Tanzania both in terms of the role of the parastatal responsible for the sector and pricing policy. Tanzania has also recently introduced regional buying centres that would seem to be an attempt to provide a more competitive seed cotton market for farmers. However, reference prices in all three EAC countries may have an important role in determining prices farmers receive. As indicated above, the minimum price policy in Malawi was not enforced in at least one year of the three years for which we have data suggesting that it operates, effectively, like an unregulated monopsony. There is no competition among ginneries in Mozambique, Burkina Faso, or Mali as each has exclusive rights in specific regions of the country but is operating in a market with a regulated price. However, the ginneries in the two West African countries are essentially state enterprises while those in Mozambique are all private companies. There are quite different non-market approaches to address the perceived market failures in the cotton sectors of the six countries studied. Country differences in terms of regulations, as well as forms of support to the sector, will be captured by the NRPs and influence their relative levels.

Overall, policies affecting cotton appear to be aimed at increasing returns and missing markets that disadvantage small-scale cotton farmers, while in the case of rice; food security is clearly a major policy objective as we will see in the next section.

\subsubsection{General Context and Policy for Rice 24}

Net rice imports accounted for an average of 34 percent of domestic supply during 2005-2010 with the share ranging from 6 percent in Tanzania to 89 percent in Kenya. Although rice is mainly produced by small-scale farmers in the eight countries studied, it is not primarily a subsistence crop consumed on farm. Even in Mali with by the far the greatest consumption per capita, only 37 percent of the rice produced is consumed on-farm (Samake and Bélières, 2007). In general, rice is a cash crop produced in competition with imports and consumed mainly by middle- and high-income consumers, in urban areas, or on special occasions. The demand for rice is therefore expected to grow rapidly with rising incomes and urbanization.

Most rice is produced using various irrigation systems although some dryland rice production takes place in all the countries studied. There are a number of different irrigation systems in the Niger basin in Mali and Burkina Faso but irrigated rice production in other countries is mostly on irrigation schemes that were established by the governments concerned. The Mwea Irrigation in Kenya for example accounted for $88 \%$ of rice production between 2005 and 2010 according to Kenya National Irrigation Board (NIB) data. According to Ruigi (1986), the schemes adopted a paternalistic command and control management system with extensive powers over most management decisions vested in NIB administrators. Plotholders did not and still do not own their land but are tenants with a renewable annual lease and pay an annual rent that in 2009 was about US\$800/ ha (Gitau et al., 2011). In Tanzania for example, higher-level bureaucrats and politicians often intervene in land allocation cases on rice schemes but village leaders and the local elite are also important players that benefit from their involvement (Therkildsen, 2011).

\footnotetext{
${ }^{24}$ This section is based on papers on Uganda by Ahmed (2012); Ghana by Angelucci et al (2013); Mali by Balié et al (2013); Tanzania by Barreiro-Hurle (2012); Nigeria by Cadoni and Angelucci (2013); Burkina Faso by Guissou and Ilboudo (2012b); Mozambique by Witwer (2012); and Kenya by Short et al (2012). See http://www.fao.org/mafap/products/country-reports-technical-notes/en/ .
} 
The price spike in global commodity markets in 2007/08 was greater for rice than any other cereal (FAO, 2010; Headey and Fan, 2010). The price spike together with import dependence and the prospects of rapidly increasing domestic demand focused concern on rice policy in most of the countries studied. The potential contribution of rice to increase the diversity in staple crop consumption, production and rural incomes were seen as additional benefits. Policymakers in the countries studied also appeared to be convinced that there were good prospects to increase rice production by their small-scale farmers. It is this combination of factors that made rice a priority commodity for policymakers in the countries studied.

This priority given to rice by policy makers is illustrated in three policy areas: the National Rice Development Strategies (NRDS) ${ }^{25}$, additional budgetary resources for infrastructure for rice production and the tariff regimes that appear to protect rice more than other staple commodities. Tanzania's objective, for instance, was to double rice production by 2018 to "develop the agricultural sector in order to attain the desired food security situation and growth for poverty reduction" according to its NRDS. Other countries included in this study have similar goals and ambitious targets. The Kenya government budgets in 2009 and 2010, for example, included new initiatives to rehabilitate and expand irrigation schemes that are mainly used for rice production. With regard to tariffs, the EAC agreed to a common external tariff (CET) of $75 \%$ while the CET for maize and wheat is set at $50 \%$ and $35 \%$, respectively. ${ }^{26}$ External tariffs generally are much lower for West African Economic and Monetary Union (WAEMU) countries but the CET for rice at $12 \%$ is higher than the $7 \%$ CET on wheat, millet and maize.

The countries studied have used a very diverse set of input subsidies for rice over the six-year study period. These range from none, in Uganda and Tanzania, to comprehensive programmes in Nigeria and Ghana that are broadly targeted in terms of commodities and farmers. In between are programmes subsidizing fertilizers and seeds and benefitting a subset of rice producers such as Mozambique's 'rice packs'. Some programmes, such as fertilizer subsidies in Mali and Burkina Faso, were introduced as a response to the 2007/08 food commodity price crisis in order to boost domestic production and reduce the dependence on international markets (Balié et al., 2013; Guissou and Ilboudo, 2012). Others were in place previously, such as Nigeria's fertilizer subsidies, or were introduced following other drivers, such as the rice component of Kenya's Economic Stimulus Programme.

The input subsidy programmes, and the research and extension programmes under the Coalition for African Rice Development (CARD), may be important factors increasing the supply of rice (Druilhe and Barreiro-Hurlé, 2012). Yields grew at an annual rate of 6.3 percent in the countries studied between 2005 and 2010 while total production only increased at 4.8 percent because of a reduction in the area cultivated.

Many of the countries studied also have parastatals for marketing major staple commodities. These generally have a dual function: to maintain a buffer stock that can be used to respond to exceptional shortfall in production resulting in a food security crisis for some segment of the population and to intervene when market prices for consumers rise above a ceiling level or fall below floor level for

\footnotetext{
${ }^{25}$ All of the countries studied have prepared NRDSs in partnership with the Coalition for African Rice Development (CARD). CARD was established by the Japan International Cooperation Agency (JICA), the Alliance for a Green Revolution in Africa (AGRA) and the New Partnership for African Development (NEPAD). The CARD strategy focuses on strengthening the production and multiplication of foundation and certified seed, research, agricultural extension, the development of agricultural land and water resources, and improved small-scale, post-harvest rice processing equipment.

26 This was effective as of Jan. 12005 . The previous tariff in Tanzania, one of the governments arguing for strong protection, was $35 \%$ (Therkildsen 2011).
} 
producers. ${ }^{27}$ Rice tends to be consumed mainly by middle and high income families and has not always been included in buffer stocks or price stabilization programmes. However, rice markets may be affected even when rice is not included in a buffer stock or price stabilization programme by spill over effects.

The level of floor and ceiling prices has important consequences for how frequently market prices trigger government or parastatal intervention. An extremely low floor price will rarely trigger a purchase and conversely, a very high ceiling price will rarely trigger a sale. When the parastatal does engage in some sort of price stabilization intervention, this may well trigger losses which will eventually require transfers from the government budget. If sufficient funds are not available, or if the parastatal has insufficient stocks to meet demand at the ceiling price, then market prices may well go outside the floor-ceiling band.

Regional and local governments in all countries studied may also affect rice markets by charges they levy. In Tanzania, for instance, a district sales tax is charged on grain "exported" from the district to any destination. The tax rate varies from district to district between one and five percent. There are fees in some countries for grain transported through a district and for marketing it in local markets. Police checks along major transportation corridors are common and provide a venue for collecting district fees and an opportunity for extra-legal charges to avoid costly delays and/or avoid compliance with load limits and other regulations, all of which are a distributional inequity type of non-market failure.

Burkina Faso and Mali have introduced new marketing policies or reverted to some pre-liberalization policies in response to the commodity price crisis of $2007 / 08$. While it has been the case in Mali since 2003, Burkina Faso began including rice in its food security stocks in 2008. Both countries used a direct price control approach to stabilize prices rather than the indirect approach of buffer stocks. Mali established price ceilings at both wholesale and retail in 2008/09. In 2005, Mali also set prices in response to a food security crisis in that year. In Mali, another important decision in 2007/08 was to mitigate food insecurity in the country by selling grain from national stocks at subsidized prices. Sales included maize (also exported in small volumes), millet and sorghum (very small volume traded, occasionally exported), and rice (massive volume imported).

Burkina Faso prices were based on estimated costs of production plus a producer margin throughout 2008 -2010. They also set margins through the rest of the supply chain implicitly controlling prices at all levels.

All the countries studied belong to one or more preferential trade agreements (PTAs) which discipline their tariffs with each other and the rest of the world. They also seek to limit the effect of non-tariff barriers. Kenya, Uganda and Tanzania are members of the EAC. Kenya and Uganda are also members of the Common Market for Eastern and Southern Africa (COMESA). Tanzania and Mozambique were members of COMESA but withdrew. They are both members of the Southern African Development Community (SADC). All four West African countries are members of the Economic Community of West African States (ECOWAS). Burkina Faso and Mali are also members of WAEMU.

Mozambique's SADC commitment specifies a zero tariff on rice imports from other SADC countries except South Africa throughout the 2005-2010 study period. The tariff on rice from South Africa was limited to 7.5 percent in 2005 and 2006, four percent in 2007 and zero thereafter. There was no SADC agreement on common external tariffs during the study period. Mozambique's MFN tariffs were 2.5 percent for the

\footnotetext{
27 Trying to use buffer stocks to stabilize prices has been criticized for a number of reasons: they replace private stocks, are subject to mismanagement and corruption resulting in high costs. Significant non-market failures can also result: parastatal stock managers may exacerbate price fluctuations because they are not better at anticipating future supplies than private stock holders (Jane, 2011; Tangermann, 2011; Timmer, 2011; Demeke et al., 2014).
} 
Harmonized System Code Customs Tariff (HS codes) that correspond to paddy, brown and broken rice in 2009 and 2010 while milled rice (HS 100630) was subject to a 7.5 percent tariff.

In the EAC, tariffs between Tanzania and Uganda and tariffs on imports by Kenya from Tanzania and Uganda were eliminated in January, 2005. Some imports from Kenya to Uganda and Tanzania were subject to tariffs, which declined linearly to zero over the period 2005-2010. In particular, the tariff on rice was 10 percent in 2005 and declined to eight percent in 2006 and six percent in 2007. The EAC agreement on CETs sets the tariff rates for all three countries on rice imports from non-EAC countries at 75 percent or US\$ 200/tonne, whichever is greater. However, Kenya received a two-year exemption in 2005, and a further two-year exemption in 2007 that set the tariff on rice imports from Pakistan at 25 percent. Another two-year exemption in 2009 set the tariff rate on imports from Pakistan at 35 percent.

Tanzania's rice exports to Uganda and Rwanda are subject to zero tariffs in accordance with the EAC agreement. EAC imports from some COMESA countries are also subject to zero tariffs on a reciprocal basis. Sudan and the Democratic Republic of Congo, which are major destinations for Uganda rice exports, are included in these trade agreements.

In addition, non-tariff charges at the border were disciplined. In compliance with the EAC agreement, Kenya charged an Import Declaration Form fee of 2.75 percent of the CIF value of the shipment. By 2009, this fee had been reduced to 2.25 percent. In Tanzania, the fee structure is more complicated but amounts to 1.4 percent of the value of the shipment plus additional charges per shipment. Uganda does not appear to charge custom and inspection services at the border.

There are no tariffs on internal trade among members of the WAEMU and they have agreed to a CET structure similar to the EAC. There are four bands: medicines, agricultural inputs and capital are zerorated; raw materials, such as crude oil and cereals for industrial processing, face a five percent tariff; semifinished product including rice and other cereals are subject to a 10 percent tariff; and final goods are allotted a 20 percent tariff. Since Mali and Burkina Faso are also members of ECOWAS, imports are also subject to an ECOWAS levy of 0.5 percent. Mali also levies an additional one percent administration fee.

ECOWAS has objectives similar to those in the EAC and WAEMU to eliminate tariffs and non-tariff barriers on internal trade and adopt a CET framework. It has succeeded on eliminating internal tariffs but has struggled with agreeing to a CET which was only adopted in March 2013 by the ECOWAS ministers of finance. Nigeria has been the 'elephant in the room' in this regard. It could not agree to proposals to harmonize with WAEMU and as a result, the current ECOWAS framework includes a fifth band at 35 percent.

There is a lack of consensus on what tariff Nigeria actually applies to rice imports. According to the WTO tariff database, Nigeria levied Most Favoured Nations (MFN) tariffs, which were five percent for paddy and brown rice and a 10 percent tariff for milled rice and broken rice in 2009 and 2010. But other fees were even larger than the tariffs according to the 2011 WTO Trade Policy Review. These consisted of the 0.5 percent ECOWAS levy, a one percent fee for the Nigeria's Comprehensive Import Supervision Scheme and a special 20 percent levy on rice. This makes for total ad valorem fees amounting to 26.5 to 31.5 percent. A USDA Global Agriculture Information Network (GAIN) reports that tariffs for 2005-2007 were 100 to 110 percent (Randon and David, 2010).

Ghana also has a complicated fee structure. It consists of a tariff of 20 percent, the 0.5 percent ECOWAS levy, a Ghana Customs Network charge of 0.4 percent, an inspection fee of one percent, an Export Development and Investment fee of 0.5 percent, a National Health Insurance levy of 2.5 percent and the 12.5 percent VAT. The VAT is not levied on domestic rice so it, like the other fees, is equivalent in impact 
to a tariff on rice. The total of all these charges on rice imports amounts to 36.9 percent. However, the tariff portion was suspended in June 2008 before being reinstated in 2009.

In addition, some of the countries studied have implemented trade bans from time to time. Mali banned rice exports in part of 2007 and all of 2008 while Tanzania threatened a ban on rice imports from COMESA countries in 2010. Tanzania had bans in place on maize exports over much of the study period which may have indirectly impacted rice value chains.

The information above is synthesized in Table 4 to provide an estimate of the tariffs and other charges levied on imports according to the major import source where the major source of imports are identified in trade statistics. These estimates are based on published information about current or recent tariffs and charges. In almost all instances, it has been necessary to infer that these are unchanged for some years. In cases where multiple tariff rates are available, the rate applicable to HS100630, milled rice, is given. Non ad valorem charges are not shown and these may be significant in some cases, such as Tanzania.

Multiple tariff rates are shown in cases where there have been changes in tariff rates or other charges introduced in the middle of a calendar year. The reductions in tariffs in Burkina Faso, Mali and Ghana in 2008 and 2009 are instances of changes that were intended to help consumers cope with high rice prices in those years. The increase in the tariff on rice imports by Kenya in 2009 was owing to its EAC commitments and the reduction in Nigeria in 2008 was related to its ECOWAS commitments. It is almost never clear when tariffs are reduced or suspended, and whether other charges are also suspended or remain in force, but the latter is generally assumed here.

If the rice markets in the countries studied are efficient with a good price transmission from the border to the farm gate, these charges should be systematically reflected in the prices at the wholesale and farm gate levels. Changes in tariff rates, such as those seen in Kenya, Burkina Faso, Mali, Ghana and Nigeria, are expected to be reflected in similar changes in the prices at the wholesale and farm gate levels and are good indicators of the effectiveness of border measures in providing price incentives in these markets.

Finally, the market segments between border and wholesale may still be impacted by both market and non-market failures. Therkildsen (2011) shows that much of the rice imported in Tanzania since 2005 was exempted from the $75 \%$ tariff and suggests that this was due to the influence of four main traders which accounted for $74-93 \%$ of rice imports in this period. Similarly, in Burkina Faso, imports are controlled by only two trading companies that are able to exercise market power and keep price high at both wholesale and retail levels so as to protect their own margins (Guissou and Ilboudo, 2012b). In Mali, three wholesalers control roughly two thirds of the rice imports and while they no longer can impose the price, they are able to exercise market power during the lean period for domestic production, and when markets can only be supplied by imports they control (Balié et al., 2013). 
Table 4: Estimates of the sum of tariffs and other ad valorem charges affecting the landed cost of rice from the major import source of each country (\%)

\begin{tabular}{|c|c|c|c|c|c|c|}
\hline & 2005 & 2006 & 2007 & 2008 & 2009 & 2010 \\
\hline Kenya $^{a}$ & 27.8 & 27.5 & 27.5 & 27.5 & 37.3 & 37.3 \\
\hline Uganda $^{\mathrm{b}}$ & 75.0 & 75.0 & 75.0 & 75.0 & 75.0 & 75.0 \\
\hline Tanzaniab & 76.4 & 76.4 & 76.4 & 76.4 & 76.4 & NA \\
\hline Mozambique $^{c}$ & 7.5 & 7.5 & 7.5 & 7.5 & 7.5 & 7.5 \\
\hline Burkina Faso $^{d}$ & 13.5 & 13.5 & 13.5 & $13.5,3.5$ & $3.5,13.5$ & 13.5 \\
\hline Malid $^{\mathrm{d}}$ & 2.5 & 12.5 & 12.5 & $12.5,2.5$ & 12.5 & 12.5 \\
\hline Ghana ${ }^{e}$ & 36.9 & 36.9 & 36.9 & $36.9,16.9$ & $16.9,36.9$ & 36.9 \\
\hline Nigeria $^{f}$ & 101.5 & 101.5 & 110.5 & $\begin{array}{c}110.5,1.5 \\
31.5\end{array}$ & 31.5 & 31.5 \\
\hline
\end{tabular}

Note: more than one tariff rate is shown in years in which there was a change in the rate levied.

${ }^{a}$ EAC Gazette.

${ }^{\mathrm{b}}$ EAC CET. Tanzania classified as an exporter in 2010.

'WTO MFN rate for $2009 / 10$.

dWAEMU rate with exemptions in 2008/09 for Burkina Faso and 2005 and 2008 for Mali. 2008/09.

'WTO MFN rates for 2009/10 with exemption for 2008/09.

fWTO MFN rates for 2009/10 and Randon and David (2010)reports for earlier years.

\subsection{Theory and method}

Estimates of the nominal rates of protection (NRPs) are used in this paper as indicators of the policy impact on prices. Some of the most seminal applications of NRPs and related concepts include Krueger et al. (1988), Monke and Pearson (1989), Tsakok (1990), and Anderson (2009). A detailed comparison of the application of NRPs and related concepts can be found in Balie and Maetz (2011). Consistent with the approach proposed by Krueger et al. $(1988,1991)$, NRPs have mainly been used to examine two situations: (i) direct taxation (or support) of the agricultural sector or a specific value chain through direct sectorspecific price policies (or interventions), and (ii) indirect taxation (or support) through trade policies, exchange rate and any other macroeconomic policies or non-agricultural sector specific policies. The analyses usually do not focus so much on specific year but rather on NRP time series and its trend. In almost all cases, the direct policy effect is equivalent to a tax on exportable goods and to a subsidy for importable goods while the indirect effect also result in taxes on agriculture which generally dominates the direct effect. For example, Quiroz and Valdes (1993) argue that, in the case of Zambia and Zimbabwe during 1980-87, there was a negative trend in nominal protection rate that was the result of increasing transport costs due to deterioration of infrastructure, lack of spare parts, and other factors that could here be qualified as non-market failures. 
Some variations on NRPs found in the literature include the nominal protection coefficient (NPC), which expresses the result as a ratio rather than as percentage change. ${ }^{28}$ The nominal rate of assistance (NRA) at the farm gate is the sum of the NRP plus subsidies paid to the farmer expressed as a percent of the adjusted border price. The subsidies may also include the value of input subsidies whether provided as payments directly to the farmer or indirectly through policies which affect farm prices (Monke and Pearson, 1989). In a developed country context, NRAs are calculated by the OECD using the Producer Support Estimate data base (OECD, 2010).

What follows is a description of how NRPs are being used in the context of MAFAP, a more detailed presentation of the method used to calculate NRPs in the framework of MAFAP can be found in BarreiroHurlé and Witwer (2013).

The point along the value chain where these indicators are calculated plays a key role. As described by Tsakok (1990), the border price and domestic price need to be compared the same point in the value chain. This leads to a number of challenges in real world applications in terms of data requirements but also makes the calculation of these indicators meaningful for policy. Monke and Pearson (1989) calculate the indicators at the farm gate. Anderson adjusts farm prices instead of border prices and therefore reports indicators at the border. This paper is closest to Tsakok (1990) with NRPs estimated at the farm gate and wholesale which helps locate market and non-market failures along the value chain.

To compare prices in a wholesale market for an imported commodity, an adjusted border price is needed to account for the costs incurred to take the commodity from a CIF position to sale in the wholesale market in question:

$B P_{w}=P_{b}+T C_{b . w}+M M_{b . w}$

where $\mathrm{BP}_{\mathrm{w}}$ is the $\mathrm{CIF}$ price (or average unit value) of the commodity converted into domestic currency using an exchange rate; ${ }^{29} \mathrm{TC}_{\text {b.w }}$ includes all handling costs at the border, transportation and any processing costs between CIF and placement of the commodity on the wholesale market; and $\mathrm{MM}_{\mathrm{b} . \mathrm{w}}$ are the importers' normal marketing margins between the border and the wholesale market. The signs would be reversed in the case of an export and with the border price being an FOB price (or unit value).

Note that the border price does not include the tariff and tariff equivalent charges. Similarly $T C_{b . w}$ includes only the resource costs of moving the commodity between border and wholesale, and $M M_{b . w}$ is a 'normal' marketing margin. The adjusted border price at the farm gate would be

$B P_{f}=B P_{w}-T C_{f . w}-M M_{f . w}$

\footnotetext{
${ }^{28}$ The NPC is the ratio of the domestic price to the border price. The NRP is the difference between the domestic price and the border price divided by the border price.

${ }^{29}$ The exchange rate used should reflect opportunity costs and should itself be adjusted in cases when the domestic currency is overvalued. African currencies have often been overvalued but most have been determined by market forces since about the 1980s. An exception is the CFA franc region in West Africa that has been tied to the French franc (and now the Euro) and Malawi for about 2008-10. Burkina Faso and Mali are included in the CFA franc region (Etta-Nkwellea et al., 2010).
} 
where $T C_{f . w}$ include all handling costs at the border, transportation and any processing costs between the farm gate and placement of the commodity on the wholesale market; and $M M_{f . w}$ are normal marketing margins between the wholesale market and the farm.

The NRP, expressed as a percentage, can then be calculated as the difference between the adjusted border price and the domestic price at wholesale and/or the farm gate:

$N R P_{w}=100 \% \times\left(W P-B P_{w}\right) / B P_{w}$

$N R P_{f}=100 \% \times\left(F P-B P_{f}\right) / B P_{f}$

In the simplest case where tariffs are the only market imperfection, Anderson (2008) shows that the NRPs at the border are equal to the tariff. In the absence of market imperfections between the border and wholesale market, it can be shown that NRP at wholesale for an imported commodity is equal to the tariff and other tariff equivalent charges multiplied by the ratio of the border price to the adjusted border price at the wholesale level. We refer to this indicator as the theoretical NRP (TNRP $\left.P_{\mathrm{w}}\right)$ which is calculated as follows

$T N R P_{w}=T \% \times B P_{b} / B P_{w}$

where $T \%$ is the tariff and other equivalent charges expressed as an ad valorum tariff. The difference between the NRPs and the expected NRPs disaggregate the effect of the tariff and other factors in the price gaps.

Similarly, in the absence of market imperfections between the farm gate and wholesale the theoretical NRP at the farm gate is

$T N R P_{f}=N R P w \times B P w / B P f$

The theoretical NRP would be the measure if only a tariff where in place. The calculated NRP, in addition to the effect of the tariff, includes the effects of market imperfections (asymmetric access to information, market power, etc.) as well as the effect of other policy measures (such as market regulations), other fees and levies, and other measures adopted by governments to generate revenue, address market failures or pursue other objectives, all of which distort price transmission between the border and the farmer. The difference at the farm gate between the actual NRP and the theoretical NRP excludes the effect of the tariff and therefore, calculating the theoretical NRPs allows for some additional insight on the impacts of market and non-market failures. 


\subsection{Results ${ }^{30}$}

\subsubsection{Results of the Analysis for Cotton}

Border prices for cotton are determined on an export basis for the countries studied so prices are expected to decline along the value chain from the border. For example, if the border price is $\$ 100$ and transport and marketing margins between the border and wholesale are $\$ 10$ then the price at wholesale would be $\$ 90$. A 5 percent export levy, in the absence of other polices and market and non-market failures, would result in a wholesale price of $\$ 85$ and an NRP at wholesale of minus 5.6 percent. In this case, costs and margins between the farm and wholesale of $\$ 25$ would result in a farm price of $\$ 60$ and an NRP at the farm gate of minus 8.3 percent. A subsidy that increased farm prices would result in less negative or positive NRPs at the farm but not affect NRPs at wholesale. Additional fees and charges or above normal marketing margins in the value chain would result in more negative NRPs.

Table 5: Farm gate nominal rates of protection for cotton

\begin{tabular}{lrrrrrrrr}
\hline & 2005 & 2006 & 2007 & 2008 & 2009 & 2010 & Mean & $\begin{array}{r}\text { Standard } \\
\text { Deviation }\end{array}$ \\
\hline Tanzania & $-33 \%$ & $-48 \%$ & $-35 \%$ & $-33 \%$ & $-4 \%$ & $-26 \%$ & $-30 \%$ & $15 \%$ \\
Uganda & $-14 \%$ & $-24 \%$ & $-19 \%$ & $-7 \%$ & $-4 \%$ & $-10 \%$ & $-13 \%$ & $8 \%$ \\
Mozambique & $-19 \%$ & $-26 \%$ & $-19 \%$ & $-39 \%$ & $-6 \%$ & $18 \%$ & $-15 \%$ & $19 \%$ \\
Malawi & $-0 \%$ & $-16 \%$ & $-15 \%$ & $51 \%$ & $8 \%$ & $-30 \%$ & $0 \%$ & $28 \%$ \\
Burkina Faso & $-5 \%$ & $8 \%$ & $-2 \%$ & $2 \%$ & $15 \%$ & $25 \%$ & $7 \%$ & $11 \%$ \\
Mali & $48 \%$ & $8 \%$ & $41 \%$ & $26 \%$ & $132 \%$ & $11 \%$ & $44 \%$ & $46 \%$ \\
\hline
\end{tabular}

Table 5 shows results for each of the countries studied for the 2005-2010 reporting period. Nearly all sales are direct exports by the ginning companies so the only market-determined prices are unit export values and farm gate prices. Therefore no indicators at the ginnery level are reported.

The NRPs for the four eastern Africa countries are consistently negative with the only exceptions being 2008 and 2009 in Malawi. The higher NRP in 2009 in Tanzania seems to indicate that farmers in that year mostly benefitted from the subsidy. The positive impact of the subsidy in Uganda in 2008 is also evident. NRPs at the farm gate are expected to be near zero in Uganda and slightly negative in Mozambique because of the export levy in that country. In fact, they average -13 percent in Uganda and -15 percent in Mozambique where they are also more variable as shown by the standard deviation. The average NRP of -30 percent in Tanzania indicates large price distortions in that country. These results indicate that farm level prices are lower than they would be in the absence of market and non-market failures. In Mozambique's case, the monopsonies exercised by the ginneries would be the obvious explanation for

\footnotetext{
${ }^{30}$ All the underlying data used for the calculations can be found in MAFAP Price Incentives and Disincentives Database, accessible at: http://www.fao.org/mafap/database.
} 
lower farm gate price levels and the negative NRPs. It seems likely that the same explanation applies to Uganda and Tanzania despite the different approaches to regulating the ginneries.

In Malawi's case, the NRPs should be near zero between 2005 and 2008, and slightly more negative than -5 percent and -8 percent in 2009 and 2010 , respectively. ${ }^{31}$ Results show that the NRPs are in fact quite erratic. They vary from -16 percent and -15 percent in 2006 and 2007 to +51 percent in 2008 all when they should be near zero. For 2009, they are 8 percent, when they should be about - 8 percent; and -30 percent in 2010, when they should be about -15 percent. It is likely that this is a result of the timing between deliveries and payments and how they are recorded by fiscal and calendar year. The average is a better indicator of the overall situation in Malawi, which indicates no distortion in farm gate prices in that country.

The results for Mali show a situation where ginners are paying higher prices for cotton to farmers and then selling the cotton for export at prices below those paid to farmers plus their market access costs. ${ }^{32}$ The treasury must eventually cover losses incurred by the ginners or the ginneries will go bankrupt and be unable to pay farmers. The consistent pattern of large positive NRPs in Mali is clearly not sustainable. There have been several bailouts of these companies in the past in Mali so the losses we report will likely result in another bailout.

NRPs at the farm gate in Burkina Faso are generally small and positive averaging +7 percent over the six years. This is what would be expected based upon the patterns of subsidies and levies in the stabilization fund..$^{33}$ However, the average NRP of +7 percent indicates the fund is gradually being depleted. To be sustainable, the fund should result in an average NRP of zero over the analysed period.

In summary, the estimates for the cotton NRPs show a consistent pattern of market and non-market failures which reduce incentives at the farm level in the countries in eastern and southern Africa. We conclude that on balance the parastatals in Burkina Faso and Mali demonstrate the same sorts of nonmarket failures that monopsonistic parastatals have demonstrated in the past arising from a combination of internalities and private goods and distributional inequity. The non-market failures in the two countries in western Africa result in higher prices than justifiable by border prices. These are clearly the result of the subsidy in Burkina Faso and Mali, although the subsidy in Mali's case is likely absorbed by the marketing parastatal. Neither is sustainable under current financial arrangements. It is not possible to determine a farm price such that the cotton ginning and marketing companies just cover their average costs until after the average selling price of the crop is known. Our results show rents are being consistently earned between the farm gate and export by the cotton ginning and trading companies. The various policies used to regulate the industry, mostly based on setting an indicative or reference prices, may mitigate but do not eliminate market failures in these value chains.

\footnotetext{
31 The Kwacha became slightly overvalued in about 2008. It is estimated that it was overvalued by $8 \%$ in 2009 and $15 \%$ in 2010.

${ }^{32}$ Of course, there could be a problem with the data used: the reported export price for Mali is low relative to that found for the other countries in the study. An administrative estimate of 0.42 was used for the outturn ratio (ginning yield) in Burkina Faso and Mali for all years. FAOSTAT data indicates that the actual outturn ratios may be a bit lower. A lower outturn ratio would reduce the reference prices at the farm gate and increase the NRPs, indicating even larger subsidies.

${ }^{33}$ The year to year variation observed in the case of Burkina Faso is inconsistent with the pattern of contributions and withdrawals from the fund. As in Malawi, it is likely that this is an issue of the timing between deliveries and with the average being a more reliable indicator.
} 


\subsubsection{Results of the Analysis for Rice}

The large tariffs described in the policy section for rice need to be accounted for in evaluating NRPs for rice. ${ }^{34}$ For example, if the border price is $\$ 100$ and transport and marketing margins between border and wholesale are $\$ 30$ then the price at wholesale would be $\$ 130 .{ }^{35} \mathrm{~A}$ tariff of 40 percent, in the absence of other policies and market and nonmarket failures, would result in a wholesale price of $\$ 170$ and an NRP at wholesale of +70 percent. Additional distortions between the border and wholesale, whether caused by additional government fees and regulations and/or non-competitive markets, would increase prices and NRPs at wholesale. If tariffs were the only distortion, costs and margins between the farm and wholesale of $\$ 25$ would result in a farm price of $\$ 145$ and an NRP at the farm gate of +45 percent. Any market and non-market failures between wholesale and farm gate would reduce prices and NRPs at the farm gate but not affect those at wholesale. However, any market and non-market failures between the border and wholesale would increase prices and NRPs at the farm gate.

Table 6 shows results for each of the eight countries studied at both wholesale and the farm gate for the 2005-2010 reporting period. The left-hand panel of Figure 11 shows the NRPs plotted against theoretical NRPs at the wholesale level given the tariffs in effect and the estimates of costs and normal marketing margins between the border and wholesale. Without distortions arising from the lack of well-functioning markets, NRPs at wholesale will equal the theoretical NRPs and the observations should cluster along the $45^{\circ}$ line while market and non-market failures should mark observations well above the $45^{\circ}$ line.

A large majority of the observations for the wholesale markets are well above the $45^{\circ}$ line including all observations for Nigeria, Ghana, Burkina Faso and Kenya, four of the six observations for Mozambique and three of the five observations for Tanzania. In all of these cases, prices at wholesale are much higher than expected indicating that in addition to border measures there are significant market and non-market failures in the value chains between the border and wholesale markets. These are caused by some combination of the effects of regulations, government fees and lack of competitive market structures in this market segment. Clearly, they result in much higher consumer prices than warranted by tariffs and the costs of bringing imported rice to market. They should result in much higher farm prices as well.

Before turning to results at the farm gate, a possible explanation for the results for Mali is needed; these may be related to regulation. The government of Mali set wholesale ceiling prices for rice in 2005, 2008 and 2009. The ceiling price was set well below access costs at least in 2008 and 2009. This might have resulted in a shortage of imports and the emergence of shadow market transactions not reflected in wholesale market prices. In Mali, rice is traditionally a far more important crop than in the other seven countries analysed. It is possible that other less formal pressures were in play in other years that resulted in gaps in reporting actual wholesale prices. The NRPs at wholesale for Uganda are also less than expected, perhaps because of similar issues.

\footnotetext{
${ }^{34}$ Except for Tanzania in 2010 when rice was evaluated on an export basis so NRPs of zero are expected at both wholesale and farm gate.

${ }^{35}$ Using average values for rice over the six years and eight countries, costs and normal marketing margins between border and wholesale were $28 \%$ of the border price; costs and normal marketing margins from farm gate to wholesale averaged $24 \%$ of the border price.
} 


\begin{tabular}{|c|c|c|c|c|c|c|c|}
\hline & 2005 & 2006 & 2007 & 2008 & 2009 & 2010 & Mean \\
\hline & \multicolumn{7}{|c|}{ Wholesale NRP } \\
\hline Kenya & $85 \%$ & $66 \%$ & $85 \%$ & $90 \%$ & $95 \%$ & $115 \%$ & $89 \%$ \\
\hline Tanzania & $20 \%$ & $38 \%$ & $27 \%$ & $18 \%$ & $46 \%$ & $3 \%$ & $25 \%$ \\
\hline Uganda & $101 \%$ & $140 \%$ & $91 \%$ & $52 \%$ & $59 \%$ & $-3 \%$ & $73 \%$ \\
\hline Mozambique & $9 \%$ & $16 \%$ & $18 \%$ & $67 \%$ & $2 \%$ & $7 \%$ & $20 \%$ \\
\hline Ghana & $46 \%$ & $79 \%$ & $74 \%$ & $58 \%$ & $30 \%$ & $55 \%$ & $57 \%$ \\
\hline Nigeria & & & $68 \%$ & $23 \%$ & $47 \%$ & $44 \%$ & $45 \%$ \\
\hline Burkina Faso & $73 \%$ & $34 \%$ & $26 \%$ & $18 \%$ & $55 \%$ & $25 \%$ & $39 \%$ \\
\hline \multirow[t]{2}{*}{ Mali } & $0 \%$ & $-3 \%$ & $-14 \%$ & $-28 \%$ & $-21 \%$ & $-26 \%$ & $-15 \%$ \\
\hline & \multicolumn{7}{|c|}{ Farm Gate NRP } \\
\hline Kenya & $111 \%$ & $84 \%$ & $117 \%$ & $106 \%$ & $105 \%$ & $115 \%$ & $107 \%$ \\
\hline Tanzania & $46 \%$ & $85 \%$ & $54 \%$ & $26 \%$ & $85 \%$ & $2 \%$ & $50 \%$ \\
\hline Uganda & $150 \%$ & $214 \%$ & $89 \%$ & $36 \%$ & $42 \%$ & $-3 \%$ & $88 \%$ \\
\hline Mozambique & $22 \%$ & $18 \%$ & $37 \%$ & $63 \%$ & $-9 \%$ & $5 \%$ & $23 \%$ \\
\hline Ghana & $53 \%$ & $87 \%$ & $90 \%$ & $86 \%$ & $6 \%$ & $-8 \%$ & $52 \%$ \\
\hline Nigeria & & & $-46 \%$ & $-74 \%$ & $-72 \%$ & $-68 \%$ & $-65 \%$ \\
\hline Burkina Faso & $105 \%$ & $29 \%$ & $22 \%$ & $16 \%$ & $41 \%$ & $14 \%$ & $38 \%$ \\
\hline Mali & $-1 \%$ & $-8 \%$ & $-20 \%$ & $-32 \%$ & $-28 \%$ & $-44 \%$ & $-22 \%$ \\
\hline
\end{tabular}




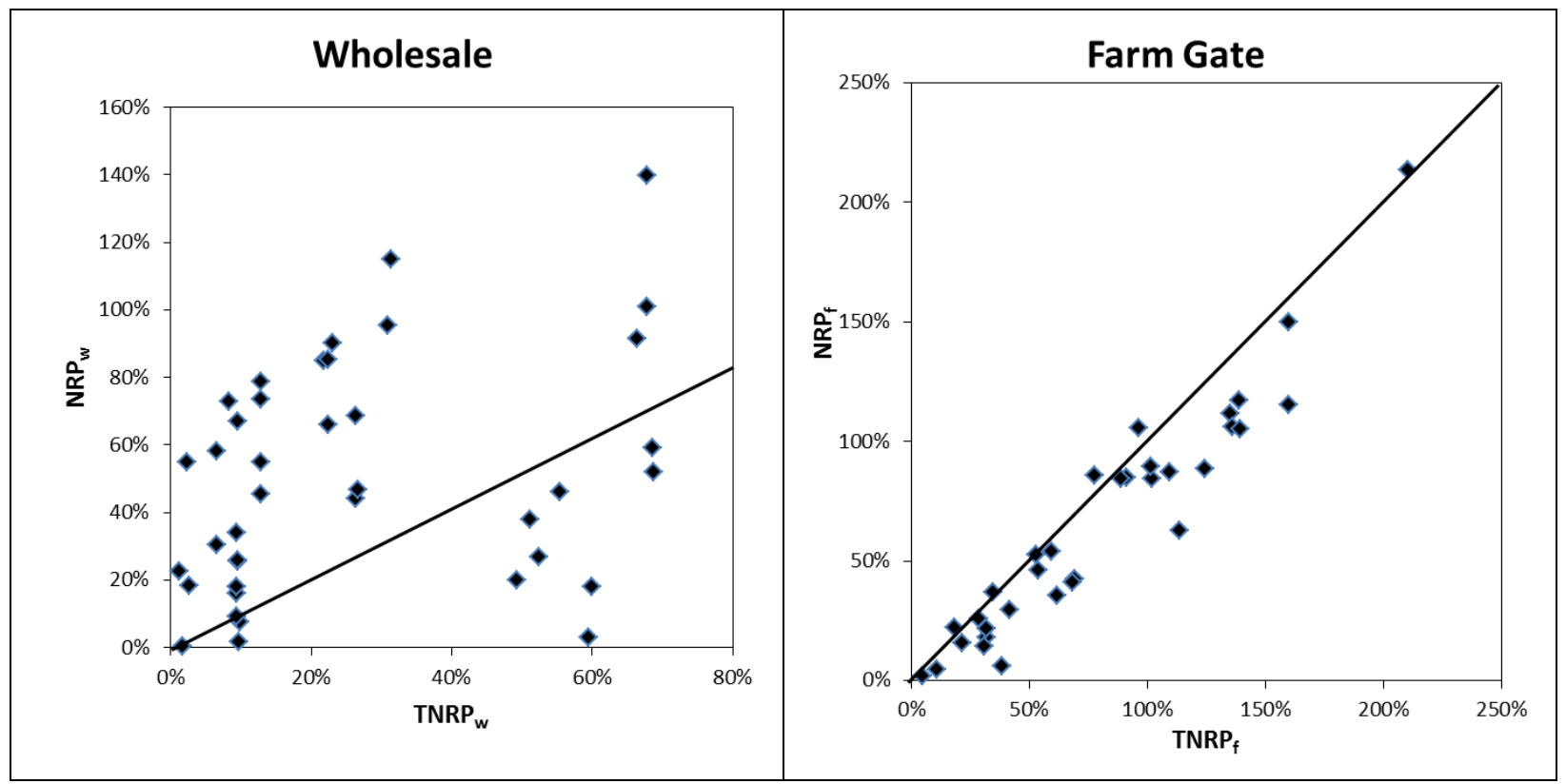

Note: The $45^{\circ}$ line for wholesale appears as a $30^{\circ}$ line because of the scaling of the axes

A simple comparison of the NRPs at the wholesale with the tariffs would seem to indicate that in most instances farmers are receiving the intended protection. On average, NRPs are somewhat larger than tariffs in all countries except Nigeria and Mali and much larger in the case of Kenya and Ghana. But this result is as much due to the market and non-market failures affecting wholesale prices as the tariffs.

Farmers, in fact, are generally receiving far less than they should, given wholesale prices. This is shown in the right-hand panel of Figure 11 where NRPs at the farm gate are plotted against their theoretical NRPs. In the absence of additional market and non-market failures between farm gate and wholesale markets, these points should bunch closely along the $45^{\circ}$ line.

Only 38 percent of the farm gate observations in Figure 11 are within 20 percent of their expected levels. The other 62 percent of observations are all much lower than expected, consistent with market power asymmetries between farmers and traders, both private and public, in the value chain segment between the farm gate to the wholesale markets. This includes all ten observations in Kenya and Nigeria, five of six observations in Burkina Faso and Mali, four of six observations in Mozambique and three of six observations in Ghana and Tanzania. It is only Uganda where the majority of NRPs are at expected levels.

Rice farmers should benefit from tariffs and other market and non-market failures between the border and wholesale that raise the wholesale price but they clearly do not in the majority of instances observed in these countries. Distortions between the wholesale market and the farm gate more than offset the additional protection provided by distortions between the border and wholesale. As was observed for cotton in the preceding section, other government policies, non-market failures and market failures such as lack of competition between the farm gate and wholesale may also have an impact on farm gate prices and NRPs. 


\subsection{Summary and conclusion}

Most African countries have gone through a similar cycle in the last three decades with respect to government involvement in the agricultural sector. In the three decades beginning in 1950, developing countries in Africa generally followed an import substitution policy together with extensive intervention in the agricultural sector in the form of price and movement controls and parastatal monopolies responsible for processing and marketing of most agricultural commodities. This began with a disengagement process in the 1980s and early 1990s driven by the lack of success of the earlier policies in delivering increased agricultural production or higher incomes for farm families and the Washington consensus for a restricted role for government and a much more market-oriented incentive system. Although the pendulum has swung back somewhat, commodity markets remain mostly liberalized and there is a new appreciation of the importance of market analysis.

The MAFAP programme put forward by FAO provides a forum where participating African governments can exchange their experience and analysis of agricultural policy. At this time, a series of studies of commodity value chains have been completed that focus on estimates of NRPs. These, in turn, are based on a large number of recent studies of transportation and handling costs, value chains, parity pricing and the like. This paper summarizes and synthesizes the analysis of cotton and rice value chains.

The price gaps, therefore, include the effects of market imperfections (asymmetric access to information, market power, etc.) as well as the effect of policy measures such as tariffs, other fees and levies, and other measures adopted by governments to generate revenue, address market failures or pursue other objectives, all of which distort price transmission between the border and the farmer. The price gap measures the actual impact on domestic prices. Disentangling the total price gap into its different components (market failure, policy, and non-market failure) is part of the analyst's task based on the nature of the data available. In the most straightforward case (i.e. a single policy in the form of an advalorem tariff) the difference between the value of the tariff and the price gap would be attributed to market failures (excessive access costs). However in reality this simple situation does not exist and additional intelligence is needed to identify the different components behind the difference.

As is common to any study using secondary statistical data from developing countries, there are many possible sources of errors in the data that may influence results: border prices, costs incurred in moving a product between the border and wholesale, the wholesale price, processing costs, the costs associated with moving a commodity between the farm and wholesale markets, and farm gate prices. However, the consistency of results across different data sources, countries and commodities suggests some confidence in them and their implied conclusions. Future MAFAP work will include additional indicators and investigate alternative sources of data as well as other analytical approaches that may contribute to a better understanding of agricultural policies and their impact in the current African context.

The governments studied have not been completely successful in eliminating rents and non-market failures in the cotton value chains. Therefore, results support the existence of non-market failures associated with the intervention on cotton value chains to solve market ones. The countries with traditional monopsony parastatals" (Bukina Faso and Mali), exhibit the traditional problems. One approach from the literature for a decreasing cost industry like cotton processing and marketing in Africa, is a policy under which the parastatals pay farmers a price that just allows them to recover the average costs incurred in marketing the crop. Alternatively, governments could follow a policy of charging marginal costs which would require regular subsidies to cover the parastatals' losses. The selling price is generally not known in the case of marketing monopsony so the price paid to producers cannot be known, under either regime, until the entire crop is sold. The Canadian Wheat Board (CWB), for example, paid farmers 
a minimum guaranteed price upon delivery to the Board and a final pooled price at the end of the marketing year when all the wheat was sold and the marketing costs were known.

It is clear that Burkina Faso's parasatals are intended to operate on a breakeven basis over time similar to $\mathrm{CWB}$. The revolving fund is a device that allows the parastatals to recover losses in one year from retained profits in other years. However, they have in fact been operating on a non-sustainable basis in the period analyzed in this paper apparently from pressure to maintain producer prices, a non-market failure that that Wolf calls derived externalities. Losses may also be caused by inefficiencies, operating rules and principal agent problems but we do not have evidence for these sources of market failure.

Similar problems beset the parastatals in Mali that tend to sell cotton at relatively low prices, pay low prices to farmers and have a negative operating margin. The low prices received may be a result of the principal agent problem or even the result of some sort of malfeasance that Wolf would classify as distributional inequity type of non-market failure. The administrative price set at harvest in Mali may be considered one of the operating rules that Wolf describes leading to an "internality and private goods" type of non-market failure. They too will require a bailout unless there are some major improvements in performance.

The other approach in the literature is to regulate prices at average costs. Again, for a marketing parastatal that exports this can only be done meaningfully after the crop is sold instead of at the beginning of crop season as is generally done in the countries analysed or at harvest in the case of Mozambique. Consequently the administrative prices should probably be thought of as indicative prices that chiefly serve as means of helping farmers decide whether they want to plant cotton or not. These countries therefore may have concluded that their best option is to allow the ginning companies to earn the rents reflected in the farm level NRPs. The use of things such as buying centres, production contracts and providing farmers with price information are all becoming more common in the EAC countries and may ultimately be the best approach to limiting rents in this industry.

Rice is regarded by governments as a priority commodity in all of the countries studied in this paper with measures to improve production technology and high levels of border protection for the domestic industry. We found that consumers pay high prices for rice resulting from both the tariffs and other levies at the border as well as market and non-market failures in the border to wholesale segment of the value chain. Unsuitable policy might be causing some of these price increases due to bribes levied at the ports and roads. However, before liberalization, imports were restricted through licensing and foreign exchange controls, allowing importers to earn large rents. Although these formal systems of controlling imports have been liberalized, it appears that competition among importers is developing only slowly and they are still able to exercise market power and earn considerable rents. Importing grain in bulk requires substantial financial resources and specialized knowledge of both international trade and markets. Perhaps it is not surprising that it takes several years for this to become a competitive activity. This is evidence of two types of non-market failures in this segment of the value chain: internalities and private goods and rent seeking resulting from distributional inequity based on power.

The picture that emerges for the farm to wholesale segments of the rice value chains is similar. The gaps between wholesale and farm prices are much larger than market access costs. Again, bribes at road check points are certainly a factor as well as official charges by local governments such as the charges at district borders noted above for Tanzania. But these are not large enough to account for the price gaps observed suggesting rents are being earned in this segment of the value chain too. The rice schemes themselves may be the result of previous government strategies often including irrigation projects and still administered by government officials. It is frequently the case that a small number of privately owned rice mills are associated with each rice scheme in Africa. In other areas, the rice schemes may be operated by 
cooperatives or government parastatals. In any combination of the above, there are systems of fees and charges for credit and other input repayment, grading the milled rice quality, and irrigation services that provide ample opportunity for non-market failure due to "Internalities and private goods" as well as rent seeking.

Even when farmers are provided with incentives, such as import tariffs for rice, these are less effective than they otherwise would be due to imperfect price transmission along the value chain with rents being captured by intermediaries as described above. Therefore, tariffs to provide an incentive to increase yields and production are ineffective. They also do not contribute to the food security goal or improve incomes of poor farmers with the policy incoherence resulting in a derived externality type of non-market failure. An increase in rice prices for consumers which reduces affordability is expected. But if the incentive to increase production is not transmitted through the value chain, then there are no off-setting benefits in terms of the other elements of food security. The overall structure results in a lack of policy coherence, leading to higher food prices for urban consumers and little or no benefit to farmers. Again policies to encourage competition, such as increased transparency, providing frequent market information and initiatives like the cotton buying centres seem to be the best policies to reduce non-market failures for rice.

This study underscores the importance of expanding agricultural sector analysis in Africa from the traditional policy focus towards the functioning of commodity value chains and interventions aimed at minimizing access costs to increase price transmission and market information to farmers. Higher prices for farmers should translate into higher incomes and more on-farm investments, as well as improved access to cheaper food for net-food buying households. Market and non-market failures will likely continue to challenge African policy makers for the foreseeable future. In future applied economics work, including through MAFAP, additional efforts are required to develop methods to more effectively disentangle the effects of market and non-market failures. Continued analysis and regional cooperation are needed to identify policy frameworks that reduce the risks of non-market failures and encourage the development of competitive markets in the African context. 


\subsection{References}

Africa Centre for Open Governance. 2009. The Maize Scandal. http://www.africog.org/reports/maizescandal (accessed May 21, 2013)

Ahmed M. 2012. Analysis of incentives and disincentives for rice in Uganda. Technical notes series, Rome: FAO, MAFAP.

Ahmed M. and S. Ojangole. 2012. Analysis of incentives and disincentives for cotton in Uganda. Technical notes series, Rome: FAO, MAFAP.

Akiyama, T., J. Baffes, D. F. Larson, and P. Varangis. 2003. Commodity Market Reform in Africa: Some Recent Experience, World Bank Policy Research Working Paper 2995.

Anderson, K. 2006. Measuring Distortions to Agricultural Incentives: Beyond Tariffs. Plenary paper presented at the Summer Symposium of the International Agricultural Trade Research Consortium (IATRC), Gustav-Stresemann-Institut (GSI), Bonn, Germany, May 28-30.

Anderson K., Editor. 2009. Distortions to Agricultural Incentives- A Global Perspective, 1955-2007., Washington DC: Palgrave Macmillan and the World Bank.

Anderson K. and M. Kurzweil. 2008. Measuring distortions to agricultural incentives, revisited. Policy Research Working Paper 4612, The World Bank Development Research Group Trade Team, Washington.

Angelucci F., J. Balié, H. Gourichon, A. Mas Aparisi, and M. Witwer. 2013. Monitoring and Analysing Food and Agricultural Policies in Africa. MAFAP Synthesis Report 2013, Rome: FAO, MAFAP Synthesis Report Series.

Angelucci F., A. Asante Poku and P. Anadumba. 2013. Analysis of incentives and disincentives for rice in Ghana. Technical notes series, Rome: FAO, MAFAP.

Annan, K. 2013. Stop the Plunder of Africa. The New York Times, (May 9, 2013). http://www.nytimes.com/2013/05/10/opinion/global/stop-the-plunder-of-africa.html? $r=1 \&$ (accessed May 21, 2013)

Baffes, J. 2002. Tanzania's Cotton Sector: Constraints and Challenges in a Global Environment. Washington, DC: The World Bank, Africa Region Working Paper Series No. 42.

Baffes, J., D. Tschirley and N. Gergely. 2010. Pricing systems and prices paid to growers. In Organization and Performance of the Cotton Sectors in Africa edited by Tschirley, Poulton and Labaste. Washington, DC: World Bank.

Balié J. 2012. Analyse des incitations et pénalisations pour le coton au Mali. Série notes techniques, Rome: FAO, SPAAA.

Balié, J., and M. Maetz. 2011. Policy analysis in Africa: A review of experiences and methods. Rome: FAO, MAFAP.

Balié J., L. Diakité, F. Diallo, J. Barreiro-Hurlé and A. Mas Aparisi. 2013. Analyse des incitations et pénalisations pour le riz au Mali. Série notes techniques, Rome: FAO, SPAAA.

Bardhan, Pranab. 2005. Institutions matter, but which ones? The Economics of Transition. 13 (3: 499532.

Barreiro-Hurle, J. 2012. Analysis of incentives and disincentives for rice in the United Republic of Tanzania. Technical notes series, Rome: FAO, MAFAP. 
Barreiro-Hurle, J. and M. Witwer. 2013. MAFAP Methodological Implementing Guides: Volume I. Analysis of price incentives and disincentives. Technical notes series, Rome: FAO, MAFAP.

Bates, R.H. 1981. Markets and States in Tropical Africa: The Political Basis of Agricultural Policies. Berkeley: University of California Press.

Benson, Todd. 2004. Africa's Food and Nutrition Security Situation-Where Are We and How Did We Get Here? Background paper prepared for the 2020 Africa Conference "Assuring Food and Nutrition Security in Africa by 2020: Prioritizing Actions, Strengthening Actors, and Facilitating Partnerships", Kampala, Uganda, April 1-3, 2004.

Brooks, J., J. Balié, P. Conforti, C. Morales Opazo, L. Bellú, M. Maetz, P. Tortora, and J. Komorowska. 2011. Programme methodology: concept paper. Rome: FAO. MAFAP.

Byerlee, D.,X. Diao, and C. Jackson . 2005. Agriculture, Rural Development, and Pro-poor Growth. Country Experiences in the Post-Reform Era. Agriculture and Rural Development Discussion Paper 21, Washington DC: The World Bank.

Byerlee, D., A. Garcia, A. Giertz, and V. Palmade. 2013. Growing Africa - Unlocking the potential of agribusiness. Washington, DC: The World Bank.

Cadoni P., and F. Angelucci. 2013. Analysis of incentives and disincentives for rice in Nigeria. Technical notes series, Rome: FAO, MAFAP.

Carfagna, E., M. Pratesi, and M., A. Carfagna. 2013. Methodological developments for improving the reliability and cost-effectiveness of agricultural statistics in developing countries. Proceedings of the 59th ISI World Statistics Congress, Hong Kong, August 25-30.

Carletto, C., D. Jolliffe and R. Banerjee. 2014. The Emperor has no Data! Agricultural Statistics in SubSaharan Africa. http://mortenjerven.com/wp-content/uploads/2013/04/Panel-3-Carletto.pdf (accessed May 4, 2014).

Dawe, D. ed. 2010. The Rice Crisis Markets, Policies and Food Security. Rome: FAO and London: Earthscan.

Dias P. 2012. Analysis of incentives and disincentives for cotton in Mozambique. Technical notes series, Rome: FAO, MAFAP.

de Gorter H., 2012. The 2012 US Farm Bill and Cotton Subsidies An assessment of the Stacked Income Protection Plan. Issue Paper 46, Geneva: International Centre for Trade and Sustainable Development (ICTSD).

Demeke, M., A. Spinelli, S. Croce, V. Pernechele, E. Stefanelli, A. Jafari, G. Pangrazio, G. Carrasco, B. Lanos, and C. Roux. 2014. Food and agriculture policy decisions. Trends, emerging issues and policy alignments since the 2007/08 food security crisis. Rome: FAPDA global report, FAO.

Derlagen, C. 2013. Analysis of incentives and disincentives for Cotton in Malawi. Technical notes series, Rome: FAO, MAFAP.

Druilhe, Z., and J. Barreiro-Hurlé. 2012. Fertilizer subsidies in sub-Saharan Africa. Working paper No. 1204, Rome: FAO, ESA.

Etta-Nkwellea, M. Jeonga, and J. G. Fanara. 2010. Misalignment of the real exchange rate in the African Financial Community (CFA zone) and its policy implications. Applied Financial Economics 20(15):12051215.

FAO. 1996. World Food Summit: Rome Declaration on World Food Security. Rome: FAO. 
FAO. 2005. Agricultural Development and Food Security in Sub Saharan Africa: Building a Case for More Support. Rome: FAO.

FAO. 2010. Price surges in food markets. Economic and Social Perspectives Policy Brief 9, Rome: FAO.

FAO, World Bank and United Nations Statistical Commission. 2012. Action Plan of the Global Strategy to Improve Agricultural and Rural Statistics. Rome: FAO.

Fengler, W. and J.Kiringai. 2009. Kenya Economic Update. Still Standing: Kenya's Slow Recovery from a Quadruple Shock with a Special Focus on the Food Crisis. Washington DC: The World Bank, Poverty Reduction and Economic Management Unit, Africa Region.

Gitau, R., S. Mburu, M. K. Mathenge and M. Smale. 2011. Trade and Agricultural Competitiveness for Growth, Food Security and Poverty Reduction: A Case of Wheat and Rice Production in Kenya, WPS 45/2011, Egerton, Kenya: Tegemeo Institute of Agricultural Policy and Development.

Ghana Ministry of Agriculture. 2009. "National Strategy for the Development of Rice Growing," http://www.riceforafrica.org/new/index.php?option=com_content\&view=article\&id=22\& Itemid=144 (accessed May 6, 2014).

Guissou R., and F. Ilboudo. 2012a. Analyse des incitations et pénalisations pour le coton au Burkina Faso. Série notes techniques, Rome: FAO, SPAAA.

Guissou R., and F. Ilboudo. 2012b. Analyse des incitations et pénalisations pour le riz au Burkina Faso. Série notes techniques, Rome: FAO, SPAAA.

Hardin G. 1968. The Tragedy of the Commons. Science 162(3859): 243-1248.

Headey, D. and S. Fan. 2010. Reflections on the Global Food Crisis. Research Monograph 165, Washington DC: IFPRI.

Hirschman, A. 1958. The strategy of economic development. New Haven: Yale University Press.

Ikiara, M. M., and L. K. Ndirangu. 2002. Developing a Revival Strategy for the Kenyan Cotton-Textile Industry: A Value Chain Approach. Nairobi: Kenya Institute for Public Policy Research and Analysis (KIPPRA).

Jane, T.S. 2011. Discussant comments on Managing price volatility: Approaches at the global, national, and household levels. Presented at the Stanford Symposium Series on Global Food Policy and Food Security in the 21st Century, Stanford, May 26

Janvry A., and E. Sadoulet. 1998. Growth, Poverty, and Inequality in Latin America: A Causal Analysis, 1970-1994. Working Paper no.784, Berkeley: University of California, Department of Agricultural and Resource Economics.

Janvry A., and E. Sadoulet. 2000. Rural Poverty in Latin America: Determinants and Exit Paths. Food Policy 25: 389-409.

Jensen, R. 2007. The digital provide: information (technology), market performance and welfare in the south Indian fisheries sector. The Quarterly Journal of Economics. 122 (3): 879-924.

Kabutha, C. and C. Mutero. 2001. From Government to Farmer-Managed Smallholder Rice Schemes: The Unresolved Case of the Mwea Irrigation Scheme. Nairobi: International Water Management Institute.

Kherallah, M., C. Delgado, E. Gabre-Madhin, N. Minot, and M. Johnson. 2000. The Road Half Traveled: Agricultural Market Reform in Sub-Saharan Africa. IFPRI Food Policy Report, Washington: IFPRI. 
Krueger, A. O., M. Schiff and A. Valdez. 1988. Agricultural incentives in developing countries: measuring the effect of sectoral and economy wide policies. The World Bank Economic Review. 2(3): 255-272.

Krueger, A. O., M. Schiff, and A. Valdés, eds. 1991. The Political Economy of Agricultural Pricing Policy. Volume 3: Africa and the Mediterranean. Washington: The World Bank.

Lang, T. 2003. Food Industrialisation and Food Power: Implications for Food Governance. Development Policy Review 21(5-6): 555-568.

Lang, T. and Heasman, M. 2004. Food Wars: The Global Battle for Mouths, Minds and Markets, London: Earthscan.

Lanos, B. and C. Roux. 2013. Food and agriculture policy decisions Trends, emerging issues and policy alignments since the $2007 / 08$ food security crisis. Rome: FAO.

Lele, U. and R. E. Christiansen. 1989. Markets, marketing boards and cooperatives in Africa: issues in adjustment policy. Discussion paper 11, Washington DC: The World Bank, MADIA.

Maetz M., M. Aguirre, S. Kim, Y. Matinroshan, G. Pangrazio and V. Pernechele. 2011. Food and agricultural policy trends after the 2008 food security crisis. Renewed attention to agricultural development. Rome: FAO.

Malawi Ministry of Agriculture and Food Security. 2006. Cotton Production in Malawi. Lilongwe: Ministry of Agriculture.

Monke E. A., and S. R. Pearson. 1989. The Policy Analysis Matrix for Agricultural Development. Ithaca, New York: Cornell University Press.

Monroy L., W. Mulinge, and M. Witwer. 2012. Analysis of incentives and disincentives for cotton in Kenya. Technical notes series, Rome: FAO, MAFAP.

Morten, J. 2014. Measuring African development: past and present. Introduction to the Special Issue. Canadian Journal of Development Studies Special Issue: Measuring African Development: Past and Present (35)1: 1-8.

Mwinuka, L. and F. Maro. 2013. Analysis of incentives and disincentives for cotton in the United Republic of Tanzania. Technical notes series, Rome: FAO, MAFAP.

Organization for Economic Cooperation and Development. 2010. OECD'S Producer Support Estimate and related indicators of agricultural support. Concepts, calculations, interpretation and use (the PSE manual). Paris: OECD.

Paarlberg, R. 2002. Governance and food security in an Age of Globalization. Food, agriculture, and the Environment. IFPRI Discussion Paper, Washington, DC: IFPRI.

Prebish R. 1950. The Economic Development of Latin America and its Principal Problems. Lake Success, New York: United Nations, Department of Economic Affairs, Economic Commission for Latin America.

Quiroz, J. and A. Valdés. 1993. Agricultural Incentives and International Competitiveness in four African Countries: Governments Interventions and exogenous Shocks. In Agricultural Policy Reforms and Regional Market Integration in Malawi, Zambia, and Zimbabwe, edited by A. Valdés and K. MuirLeresche, Washington DC: IFPRI.

Rocha, C. 2006. Food Insecurity as Market Failure: A Contribution from Economics. Working paper, Toronto: Ryerson University, Centre for Studies in Food Security. 
Rodrik, D. 2006. Goodbye Washington Consensus, Hello Washington Confusion? A Review of the World Bank's Economic Growth in the 1990s: Learning from a Decade of Reform. Journal of Economic Literature (XLIV:) 973-987.

Rondon M., and M. David. 2010. Nigeria Grain and Feed Annual. GAIN Report Number NI11015: Washington, DC: USDA Global Agriculture Information Network.

Ruigi, G. M. 1998. Large-Scale Irrigation Development in Kenya Past Performance Future Prospects. Report No. 23, Nairobi: Ministry of Planning and National Development, Food and Nutrition Planning Unit.

Samake A., J-F. Belieres, P-M. Bosc, and O. Sanogo. 2007. Les implications structurelles de la libéralisation sur l'agriculture et le développement rural. Première phase. Synthèse nationale. Bamako, Mali : CEPIA - IER / Cirad, République du Mali, Banque mondiale, et Coopération Française.

Short C., W. Mulinge and M. Witwer. 2012. Analysis of incentives and disincentives for rice in Kenya. Technical notes series, Rome: FAO, MAFAP.

Stiglitz, J. E. 2001. Information and the Change in the Paradigm in Economics. Nobel Prize lecture presented at Aula Magna, Stockholm University, December 8.

Stiglitz, J. 2002. Globalization and its Discontents. New York: W. W. Norton \& Company.

Sturgess, I. M. 2008. Self-sufficiency and food security in the UK and the EC. Journal of Agricultural Economics 43(3): 311-326.

Tangermann, S. 2011. Policy Solutions to Agricultural Market Volatility: A Synthesis. Issue Paper No. 33, Geneva: Programme on Agricultural Trade and Sustainable Development, International Centre for Trade and Sustainable Development.

Therkildsen, O. 2011. Policy making and implementation in agriculture: Tanzania's push for irrigated rice. DIIS Working Paper 2011:26, Copenhagen: Danish Institute for International Studies.

Timmer, P. 2011. Managing Price Volatility: Approaches at the global, national, and household levels. Presented at the Stanford Symposium Series on Global Food Policy and Food Security in the 21st Century, Stanford: May 6.

Transparency International, Corruption Perceptions Index 2012. http://www.transparency.org/whatwedo/pub/corruption perceptions index 2012 (accessed May 2, 2013.)

Toulmin, C, and B.Guèye, 2003. Transformations in West African agriculture and the role of family farms. Issue paper number 123. IIED.

Tschirley, D., C. Poulton and P. Labaste, Eds. 2009. Organization and Performance of Cotton Sectors in Africa: Learning from Reform Experience. Agriculture and Rural Development Series, Washington DC, World Bank.

Tschirley, D., C. Poulton, N. Gergely, P. Labaste, J. Baffes, D. Boughton and G. Estur. 2010. Institutional Diversity and Performance in African Cotton Sectors. Development Policy Review 28(3): 295-323.

UK Department for Environment, Food and Rural Affairs. 2009. Food Security Assessment: Detailed Analysis. London: Department for Environment, Food and Rural Affairs.

Wiggins, S. and H. Leturque. 2010. Raising agricultural productivity in Africa: Options for action, and the role of subsidies. Africa Progress Panel Policy Brief. http://www.africaprogresspanel.org/en/issues/agriculture-and-food-security/ (accessed May 2013) 
Williamson, J. 1989. What Washington Means by Policy Reform. In Latin American Readjustment: How Much Has Happened edited by J. Williamson. Washington DC: Institute for International Economics.

Williamson J. 2000. What Should the Bank Think about the Washington Consensus? World Bank Research Observer 15 (2): 251-264.

Williamson, J. 2002. Did the Washington Consensus Fail? Outline of a speech at the Center for Strategic and International Studies, Washington DC, November 6.

http://www.iie.com/publications/papers/paper.cfm?ResearchID=488 (accessed on Apr 30, 2014).

Witwer, M. 2013. Analysis of incentives and disincentives for rice in Mozambique. Technical notes series, Rome: FAO, MAFAP.

Wolf, C. Jr. 1979. A theory of nonmarket failure: framework for implementation analysis. Journal of Law and Economic 22(1): 107-139.

World Bank. 2008. World Development Report 2008: Agriculture for Development. Washington DC : The World Bank.

World Bank, FAO and the United Nations Statistical Commission. 2011. Global Strategy to Improve Agricultural and Rural Statistics. Washington, DC: The World Bank. 


\section{Myths and realities about inputs subsidies in Sub-Saharan Africa ${ }^{36}$}

\subsection{Introduction}

As the Millennium Development Goals process ends in 2015, governments worldwide, not the least African governments, will seek to attain new Sustainable Development Goals for the year 2030. After being severely challenged in the mid-1980s and 1990s, with disappointing results for agricultural development and food security (Jayne et al. 2002; Dorward et al., 2004), the role of the African States in steering development is being reemphasized (Akyüz and Gore, 2001; Cabral and Scoones, 2006). This is particularly true of the agricultural sector, which is regaining prominence as an engine of growth, following decades of distrust by African policy-makers and the donor community alike (World Bank, 2007; Diao et al.,2007; Wiggins, 2014). However, the modest record of African State interventionism and agricultural taxation of the 1970s, in terms of agricultural development (Krueger, 1990; Anderson and Masters, 2009; Diao et al., 2010), has led to intense debates on the adequate public policy stance governments should follow. A nexus, for these discussions, is the political economy (Anderson, 2010; Poulton, 2014), degree and form of intervention of the government in agricultural markets, in particular through public investment, to correct market failures, on one hand, and favour income distribution and poverty reduction, on the other (Benin et al., 2009). Indeed, with limited capacities to intervene through monetary policies (Weeks, 2010) and to enforce regulation, and for institutional and political reasons (Bates, 1981), African governments tend to put the fiscal policy, and especially public spending, at the centre of the public policy effort for agricultural development. This prominence of public spending as an avatar of public policy is accentuated by the role of aid in African countries, which leads donors to invest this peculiar policy space, albeit to a varied extent (Moss et al., 2006; Booth, 2011; Booth and Golooba-Mutebi, 2014). In addition, public resources for the agricultural sector tend to be scarcer than for other sectors (Mogues et al., 2012).

In such a context, monitoring and analysing public expenditures in support of food and agriculture (PEA) is of the utmost importance for African governments and donors alike. This stands true, in particular, for input subsidies. This form of public spending is indeed attracting a renewed interest from African policymakers since the 2000s (Wiggins and Brooks, 2010), sparkling intense discussions over its merits versus those of other types of agricultural expenditures such as research or infrastructure. It is however a paradox that, despite the emphatic debate on input subsidies, so little reliable, comparable and detailed evidence exists on the level and composition of this form of public spending in African countries (Mas Aparisi et al., 2015). Input subsidies are often seen as bulging, inefficient seeds and fertilizers' programmes clogging agricultural budgets. But does this correspond to the actual trends of input subsidies in several African countries - their level, composition and technical efficiency ${ }^{37}$ ? The current paper aims to answer this question by reviewing the trends of input subsidies in nine African countries over the 2006-13 period. It uses the methodology and work carried

\footnotetext{
${ }^{36}$ This paper is a joint work with two FAO colleagues, Léopold Ghins, Alban Mas Aparisi published under the title Myth and realities about trend and efficiency of input subsidies in Sub-Sharan Africa in the Development Policy Review, June 2016.

${ }^{37}$ In this essay, we refer to the definition of technical efficiency used by the World Bank's Ag PER Toolkit (see p.19 for example).
} 
out by the Monitoring and Analysing Food and Agricultural Policies (MAFAP) programme, implemented by the Food and Agriculture Organization of the United Nations (FAO) in several developing countries.

\subsection{Method and data}

To analyse the trends of input subsidies in Sub-Saharan African (SSA) countries, one needs to mobilize a dataset containing reliable and sufficiently disaggregated measures of spending on input subsidies and on other categories of PEA that are comparable across countries. The low availability of such data and the challenge it represents for policy research has been regularly flagged by the international community (AU, 2014; UN, 2014) and the academia (Benin and Binswanger-Mkhize, 2012). In this context, the current study chooses to use the PEA dataset recently compiled by the MAFAP programme of FAO. The purpose of MAFAP is to establish agricultural policy monitoring and analysis systems in a growing number of developing economies.

To collect and classify PEA, MAFAP uses a specific methodology, which was developed with the Organisation for Economic Co-operation and Development (OECD) and builds on the Producer Support Estimate (PSE) framework for policy analysis. Expenditures are classified according to the way in which the policies they fund are implemented. The categories to which expenditures are allocated are designed to reflect the types of policies applied in African countries (Komorowska, 2010; OECD, 2010; FAO, 2015e). The categories used are listed in a classification table, which is given in Annex page 81and also contains the category definitions. As the same table and classification method was used in all countries in which a MAFAP PEA database was constructed, the amounts are comparable across countries.

The table captures the following distinctions:

i. A broad distinction between expenditures that are agriculture-specific (direct support for the agricultural sector), and agriculture-supportive (indirect support for the agricultural sector).

ii. Within the agriculture-specific category, a distinction between transfers towards private goods (support for producers and other agents in the value chain, for example input subsidies), and transfers towards public goods (general or collective support for the sector, for example research).

Within the MAFAP PEA classification, agriculture-specific expenditures are referred to as category 1. Input subsidies are a sub-component of agriculture-specific expenditures, and are defined as category B. This category is further disaggregated into "B1 - variable inputs" (seeds, fertilizers, energy, credit, etc.), "B2 - Capital" (machinery and equipment, on-farm irrigation, other basic on-farm infrastructure, etc.) and "B3 - On-farm services" (pest and disease control, veterinary services, on-farm training, technical assistance, extension, etc.). The sum of categories B1, B2 and B3 equals category B. As the whole MAFAP PEA table follows this "tree" structure, spending amounts are comparable across categories. In the current study, other categories are also used. When so, it is specified in the text. These other categories include "I - Agricultural research", "K - Training", "L - Extension" and "N Agricultural infrastructure".

In order to analyse the series constructed on the basis of the MAFAP PEA methodology, this paper relies on descriptive statistics. Shares of particular spending categories within, for instance, agriculture-specific expenditures are computed and compared across countries. One also looks at the 
evolution of spending amounts in nominal and real terms and at the trends of the agricultural public expenditure relative to the agricultural Gross Domestic Product (GDP) and total GDP over the years.

The MAFAP PEA dataset contains yearly expenditure amounts for the categories listed in the MAFAP classification table. The dataset covers nine African countries, namely Burkina Faso, Ethiopia, Ghana, Kenya, Malawi, Mali, Mozambique, the United Republic of Tanzania and Uganda. The covered period is $2006-13$, with variations across countries (see Annex page 81 ). When years were missing, averages were computed without including these years.

For each country, each expenditure category and each year, the MAFAP PEA dataset provides with budgeted and actual expenditures. It also makes the difference between expenditures arising from national and donor sources. One can therefore compute, for instance, the share of actual, budgeted, donor or national spending within total PEA or within selected PEA categories, for each year. Given this structure and the data gaps, the MAFAP PEA dataset contains 62 observations for each year, category, spending type (budgeted or actual) and spending source (donor or national). Unless specified, the expenditure amounts used in the current paper correspond to total (donor + national) and actual (not budgeted) spending.

The sources of the data gathered in the MAFAP PEA database are either official government sources (line ministries, statistical institutes or research centres) or donor sources. The major data sources are the ministries of agriculture and finance. The expenditure values were collected and compiled by the MAFAP country teams. The expenditures are grouped per program or project directed towards the agricultural sector and further disaggregated into activities. These activities are then associated to the categories in the MAFAP PEA classification table (FAO, 2015d).

As all the expenditure amounts in the original MAFAP PEA database are expressed in nominal, local currency terms, these were converted into constant 2011 United States Dollars (USD) by first dividing the Local Currency Unit (LCU) series by a national inflation index whose value is 1 in 2011 and then dividing the amounts of that constant series by the 2011 LCU/USD exchange rate, for each year. However, the analysis relies heavily on comparisons of spending ratios, which remain identical, be they expressed in nominal currency terms or in constant 2011 USD. Moreover, expenditure amounts per farm or as a proportion of GDP or agricultural GDP were computed. A table providing with a list and description of the data series used in this study is given in Annex page 81.

\subsection{Results}

Beyond the mere level of public expenditures allocated to the agricultural sector, their very composition is critical to ensure they are effective in fostering the agricultural sector's development. This has been acknowledged politically by African States in the Malabo declaration of the African Union (AU, 2014).

There is also a body of literature on the efficient allocation of PEA (Fan et al. 2008; Benin et al. 2009). It tackles, among other topics, the question of public resources allocation towards the provision of public goods over private goods, in particular input subsidies. It is frequently argued that the use of input subsidies has resurged in African States since the 2000s (Jayne and Rashid, 2013), not the least for the political benefits they reap (Chinsinga, 2012; Mason et al., 2013) and their straightforwardness as a policy measure (Wiggins and Brooks, 2010). These assessments tend to rely on case studies of input subsidy programmes and their associated budgeted expenditures (Baltzer, 2011; Ricker-Gilbert 
et al., 2013; Jayne and Rashid, 2013). A shortcoming for this approach is that although some programmes may be labelled as "input subsidy programmes", they are often used as vehicles for a breadth of other agricultural development activities, including those providing collective goods to the sector, such as training and extension or the construction of off-farm infrastructure (Komorowska, 2010). It is therefore not straightforward to build on these studies to determine the exact portion of agricultural budgets that consists in input subsidies. Also, it is of interest to detail the interventions that stand behind spending on input subsidies, how these expenditures evolve through time and what is their execution rate. Further, the role of aid in funding input subsidies should be examined.

\subsubsection{The share of input subsidies in agricultural budgets varies across countries}

The MAFAP dataset reveals that over the period 2006-13, input subsidies have represented an average $35 \%$ of agriculture-specific expenditures in the countries that were analysed. ${ }^{38}$ This average masks three main groupings of countries. Low spenders are Ethiopia, Kenya and Uganda, with respective shares of 12, 15 and $24 \%$. Average spenders are Burkina Faso, Ghana, Mali, Mozambique and the United Republic of Tanzania (URT), with shares oscillating between 31 and $46 \%$. Malawi forms its own high-spending group, with a staggering share of $69 \%$ (Figure 12).

The same pattern can be observed when considering the average shares of input subsidies in GDP and agricultural GDP (Figure 12). Ghana is a specific case. Although input subsidies do constitute a large proportion of agricultural expenditures, at $36 \%$, they only account for $0,2 \%$ of the country's GDP and $0,6 \%$ of the agricultural GDP. There is indeed an important imbalance between public spending in the agricultural sector and the value added it produces.

Figure 12: Share of input subsidies over agriculture-specific expenditures (right axis), agricultural GDP and overall GDP (left axis) in nine African countries, average 2006-13.

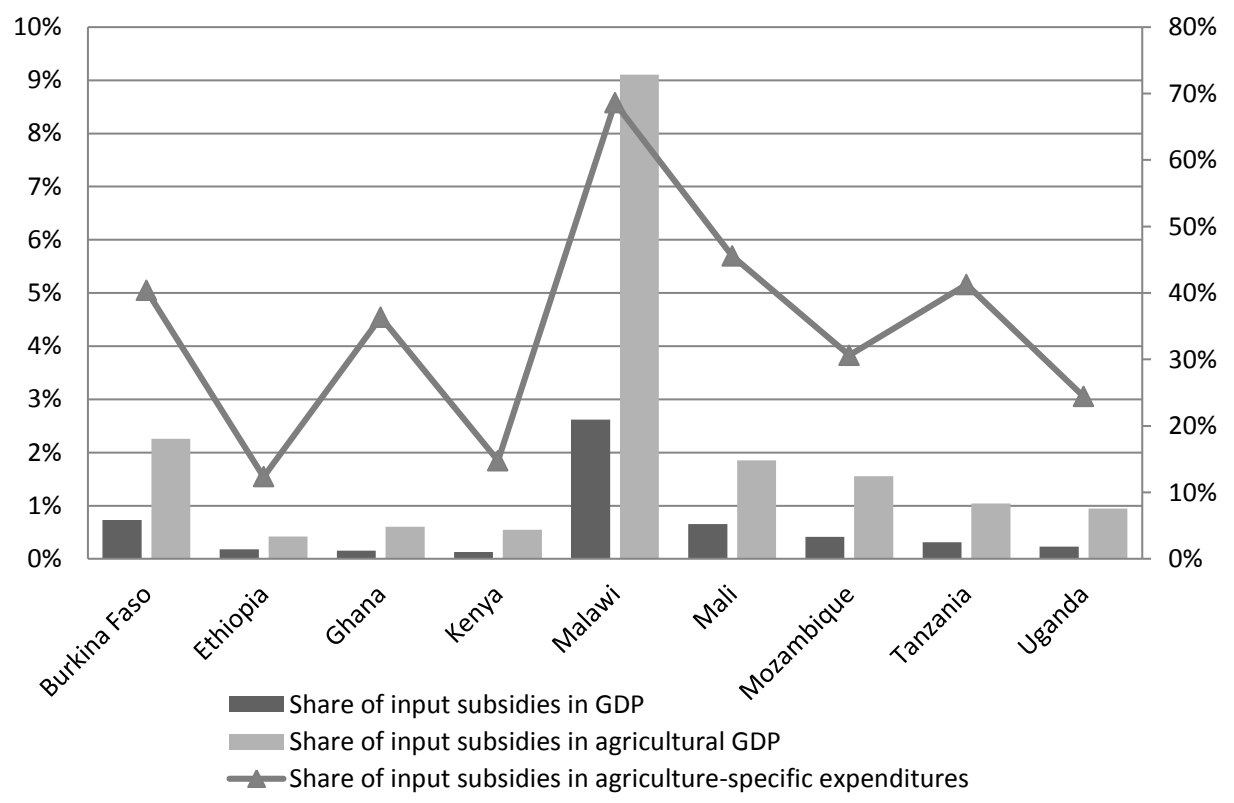

Source: The authors.

This overall pattern does not come as a surprise: the costs and benefits of Malawi's colossal input subsidies programme have been intensely debated by the academia (Wiggins and Brooks, 2010;

\footnotetext{
${ }^{38}$ The MAFAP methodology considers agriculture-specific and agricultural-supportive expenditures as PEA, which includes rural investments. See "methodology section".
} 
Shively and Ricker-Gilbert, 2013) and, generally, by actors involved in agricultural policies. The case of Malawi has often been considered a benchmark to evaluate the relevance of input subsidies in Africa.

However, the results hereby presented suggest that Malawi's specifics cannot be considered a metonymy of African countries' expenditures pattern. Input subsidies do represent more than a third of the agricultural expenditure in most countries, but do not exceed half of it, except in Malawi. The outlier status of Malawi is even more visible if one considers expenditures on input subsidies as a share of GDP or agricultural GDP. Indeed, whereas the average share of input subsidies in overall GDP and in agricultural GDP stood below 1 and $2 \%$ respectively in all other reviewed countries, in the case of Malawi, these shares stood at 2.6 and more than $9 \%$, respectively. ${ }^{39}$

\subsubsection{The composition of input subsidies is more diversified than usually thought}

The very structure of input subsidies, for the period and countries analysed bears interesting characteristics. Input subsidies are frequently seen as a synonym for variable inputs, such as fertilizer and seeds. However, subsidized capital (on-farm equipment for instance) and subsidized on-farm services (inspection for instance) should not be overlooked (FAO, 2015e). Although variable inputs have accounted for $59 \%$ of input subsidies, capital and on-farm services have benefited, respectively, from 32 and $10 \%$ of them. Sahelian countries (Mali and Burkina Faso) have even subsidized capital, essentially on-farm irrigation, more than seeds and fertilizers (Figure 13). This is due to the geo-climatic characteristics of these countries, where access to water poses an important challenge. Kenya has also invested more in on-farm capital than in variable input subsidies.

\footnotetext{
${ }^{39}$ With the exception of Burkina Faso, for which the average share of input subsidies within agricultural GDP stands slightly above $2 \%$.
} 
Figure 13. Expenditures in support of on-farm services, capital and variable inputs for nine African countries, average for the 2006-13 period, constant 2011 USD per farm.

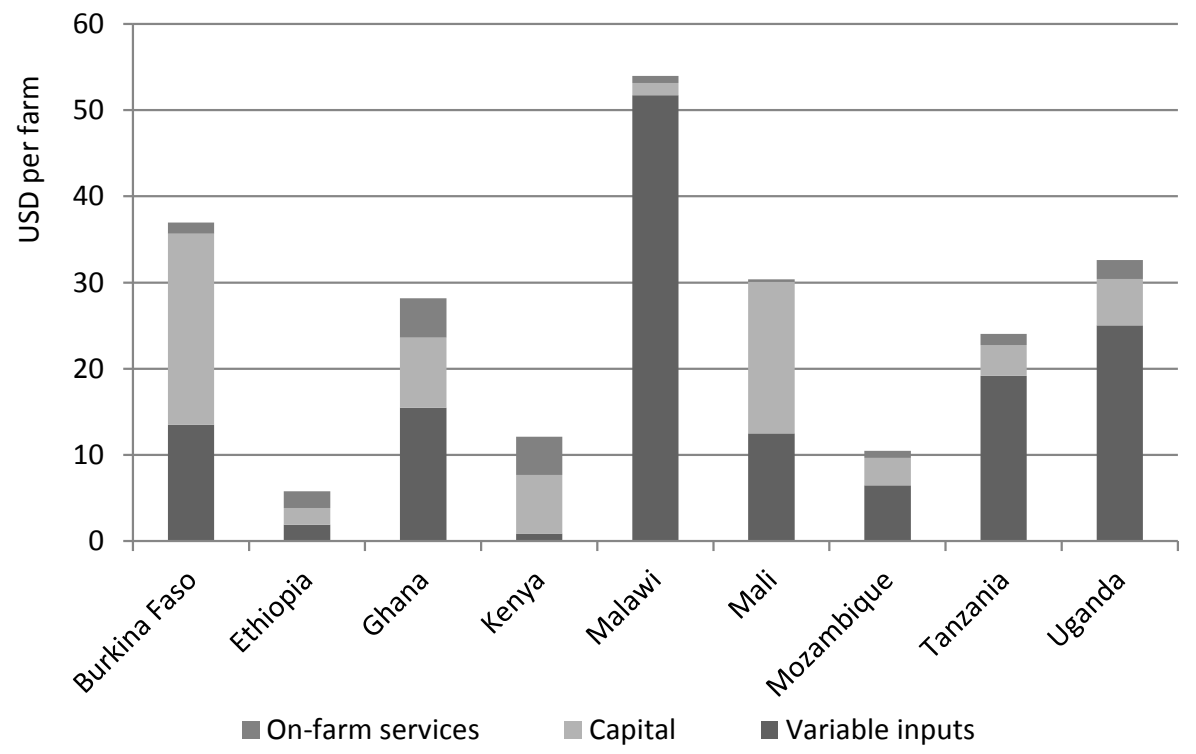

Source: The authors.

Variable input subsidies have represented an average $23 \%$ of agriculture specific expenditures for the nine countries over the period, and $17 \%$ if Malawi is not included. Hence, our results show that subsidies to seeds and fertilizers represent a moderate part of agricultural budgets in all countries but Malawi. However and as already pointed out above, they occupy a lofty share of agricultural expenditures when taken jointly with subsidized capital and on-farm services (Table 7). 


\begin{tabular}{lcccc}
\hline & $\begin{array}{c}\text { Variable } \\
\text { inputs }\end{array}$ & Capital & $\begin{array}{c}\text { On-farm } \\
\text { services }\end{array}$ & Total \\
\hline Burkina Faso & $15 \%$ & $24 \%$ & $1 \%$ & $41 \%$ \\
Ethiopia & $3 \%$ & $4 \%$ & $4 \%$ & $11 \%$ \\
Ghana & $23 \%$ & $9 \%$ & $5 \%$ & $38 \%$ \\
Kenya & $1 \%$ & $8 \%$ & $5 \%$ & $14 \%$ \\
Malawi & $72 \%$ & $2 \%$ & $1 \%$ & $75 \%$ \\
Mali & $20 \%$ & $25 \%$ & $0 \%$ & $45 \%$ \\
Mozambique & $19 \%$ & $9 \%$ & $2 \%$ & $30 \%$ \\
Tanzania & $35 \%$ & $6 \%$ & $2 \%$ & $44 \%$ \\
Uganda & $19 \%$ & $3 \%$ & $1 \%$ & $24 \%$ \\
Average & $23 \%$ & $10 \%$ & $3 \%$ & $36 \%$ \\
Average without & $17 \%$ & $11 \%$ & $3 \%$ & $31 \%$ \\
Malawi & & & & \\
\hline
\end{tabular}

Source: The authors.

\subsubsection{Input subsidies are embedded in agricultural budgets over time displaying no better execution rates than other categories}

The MAFAP dataset shows that the share of input subsidies in the agricultural budget is not decreasing substantially over the eight-year period analysed, on average for all countries (Table 8). On the contrary, three countries display important positive growth rates: the United Republic of Tanzania (7.8 $\%)$, Mali (7.5\%) and Malawi (6.42 \%). The trend also verifies when considering the average growth rates of input subsidies per farm with $+14 \%,+12 \%,+4 \%$ for Tanzania, Mali and Malawi respectively. This ratio applied to Burkina Faso and Ghana further indicates that these two countries could be clustered with the previous group as they have invested more resources on input subsidies per farm over time with growth rates of input subsidies per farm of $+7 \%$ and $+12 \%$ respectively.

Mozambique, Ethiopia and Kenya exhibit negative growth rates. For Kenya however, it is rather the result of the substantial increase in agricultural-specific expenditures that occurred between 2007 and 2008, which was not followed by a proportional increase in input subsidies. Furthermore, input subsidies per farm expressed in constant 2011 USD have increased significantly in all countries but Mozambique. Only in this latter country have expenditures on input subsidies, expressed in nominal, local currency terms, diminished substantially over the period. Overall, there is compelling evidence that input subsidies are not being phased out in the countries reviewed here.

Our results tend to confirm the well-known tendency for input subsidies to morph into a recurrent expenditure once implemented, clogging agricultural budgets whereas they are intended to be a short- 
term measure (Wiggins and Brooks, 2010).

Table 8: Share of input subsidies within agriculture-specific expenditures in nine African countries, and input subsidies per farm in constant 2011 USD, average exponential growth rates over the 2006-13 period.

\begin{tabular}{lcc}
\hline & $\begin{array}{l}\text { Share of input subsidies within } \\
\text { agriculture-specific expenditures, } \\
\text { growth rate }\end{array}$ & $\begin{array}{l}\text { Input subsidies per } \\
\text { farm, growth rate }\end{array}$ \\
\hline Burkina Faso & $-0.8 \%$ & $13 \%$ \\
Ethiopia & $-17.9 \%$ & $16 \%$ \\
Ghana & $2.8 \%$ & $48 \%$ \\
Kenya & $-5.7 \%$ & $15 \%$ \\
Malawi & $6.4 \%$ & $29 \%$ \\
Mali & $7.5 \%$ & $18 \%$ \\
Mozambique & $-17.7 \%$ & $-5 \%$ \\
Tanzania & $7.8 \%$ & $33 \%$ \\
Uganda & $-1.3 \%$ & $20 \%$ \\
Average & $-2.1 \%$ & $20.6 \%$ \\
\hline
\end{tabular}

Source: The authors.

The inertia of spending on input subsidies, or even growth for some of the countries studied, is all the more concerning given their already hefty share in agricultural budgets. Input subsidies account for an average $36 \%$ of the agricultural expenditures, in the countries analysed and over the period (Table 8). Input subsidies per farm, expressed in constant 2011 USD, grew at an average rate of $20.6 \%$ during the period considered and across all countries reviewed Agricultural research expenditure (ARE) per farm and agricultural infrastructure expenditure (AIE) per farm also grew positively, at about $26 \%$ and $29 \%$ respectively, but they only accounted for ten and $11 \%$ of agricultural budgets respectively (Figure 14). Knowledge dissemination expenditure (KDE) per farm, which is recognized as a crucial area of expenditure to ensure effective uptake of research, increased at an average rate of about $21 \%$, which is about as much as expenditures on input subsidies per farm. In addition, ARE, AIE or KDE all represented less than 0.5 per cent of overall GDP or 1 per cent of agricultural GDP, on average for the reviewed period, considering all countries. By contrast, expenditures on input subsidies represented $0.6 \%$ of overall GDP and $2.3 \%$ of agricultural GDP, on average in all countries for the period considered here. 
Figure 14: Average exponential growth of the expenditures per farm on input subsidies, research, knowledge dissemination and agricultural infrastructure (in constant 2011 USD) in nine African countries, 2006-13 period, in \%.

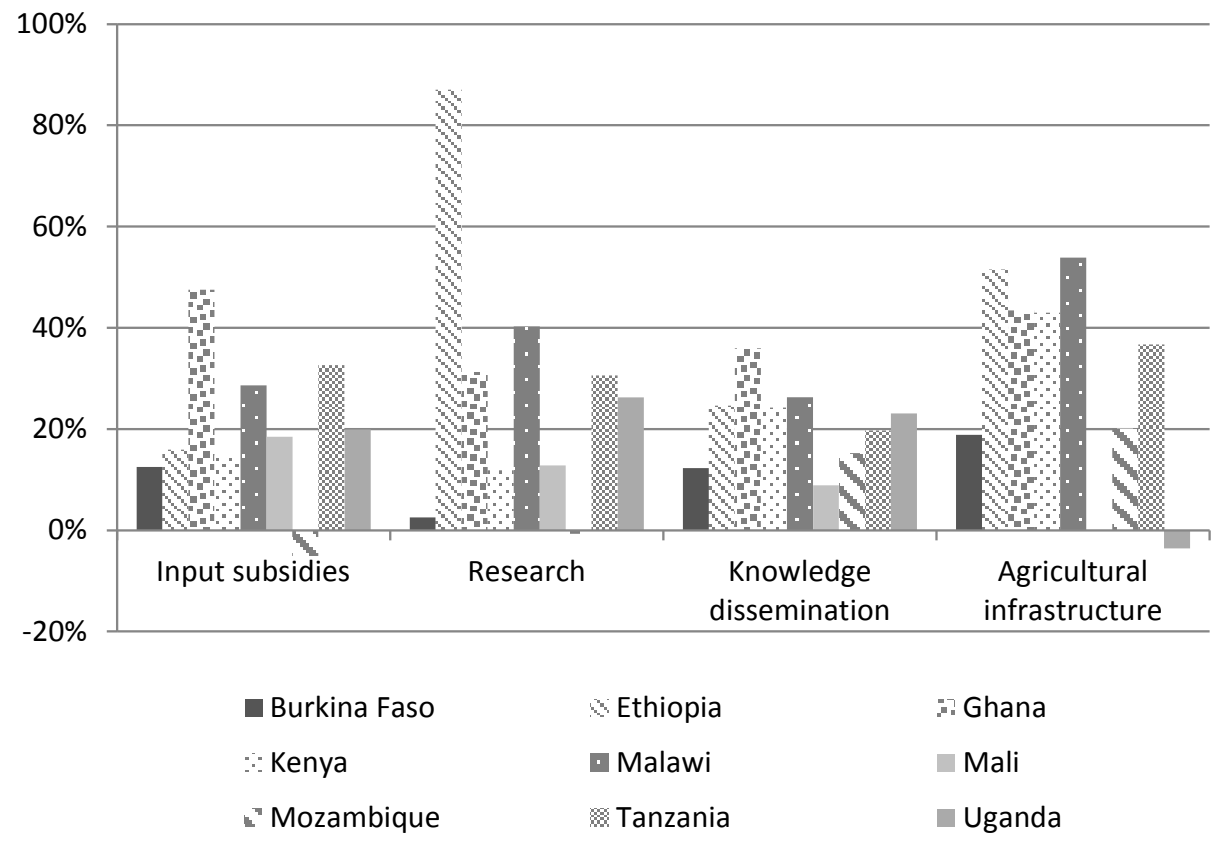

Source: The authors.

Our results also show that the budget execution rate of input subsidies - for the period and countries analysed - has also been less than optimal. It is measured as a ratio of actual expenditures over budgeted ones, namely the execution rate. Average execution rates for input subsidies have reached $86 \%$, leaving room for improvement. However, such rates have been on par with the average execution rate for other categories of agriculture-specific expenditure taken together, which stands at $83 \%$, leading to a differential of $3 \%$ (Annex 4.6.4). ${ }^{40}$ Nevertheless, it should be noted that the positive differential between input subsidies' and agricultural expenditures' execution rates turns to zero when the data for Malawi is counted out. Indeed, Malawi's input subsidies have an unlikely execution rate of $103 \%$.

By comparison, the average differential between input subsidies' execution rates and those of ARE and $\mathrm{KDE}$, with Malawi out, stands at four points and -1 point respectively. It is at -1 point for AIE. While the execution rates of input subsidies are not optimal, other contrasting expenditure measures such as knowledge dissemination or infrastructures exhibit the same problem. By contrast, agricultural research budgeted expenditure is better executed than other categories of agriculture-specific expenditures, mostly because it primarily includes spending on human capital (salaries of researchers).

\footnotetext{
${ }^{40}$ These percentages refer to the differentials obtained when computing execution rates on the basis of total expenditures (the sum of donor and national spending).
} 


\subsubsection{Aid tend to focus on other categories than input subsidies}

Intuitively, donors should tend to support the provision of public rather than private goods. Indeed, they are inclined to perceive private payments as ineffective and unsustainable, whilst they are not after the political benefits that national governments may be seeking through input subsidies. This verifies in the data used here. The share of national expenditure is higher within total spending on input subsidies than within spending dedicated to the provision of selected public goods (agricultural research, knowledge dissemination and agricultural infrastructures) in most of the reviewed countries (Figure 15). ${ }^{41}$ Excluding Kenya and Ghana, $70 \%$ of expenditures on input subsidies originated from national sources on average over the period, whilst this share was of only $47 \%$ for expenditures on agricultural research, knowledge dissemination and agricultural infrastructures taken jointly.

Figure 15: Share of national expenditures within total expenditures on input subsidies (IS) and selected public goods (PG, defined as the sum of ARE, KDE and AIE), average for the 2006-13 period, in \%.

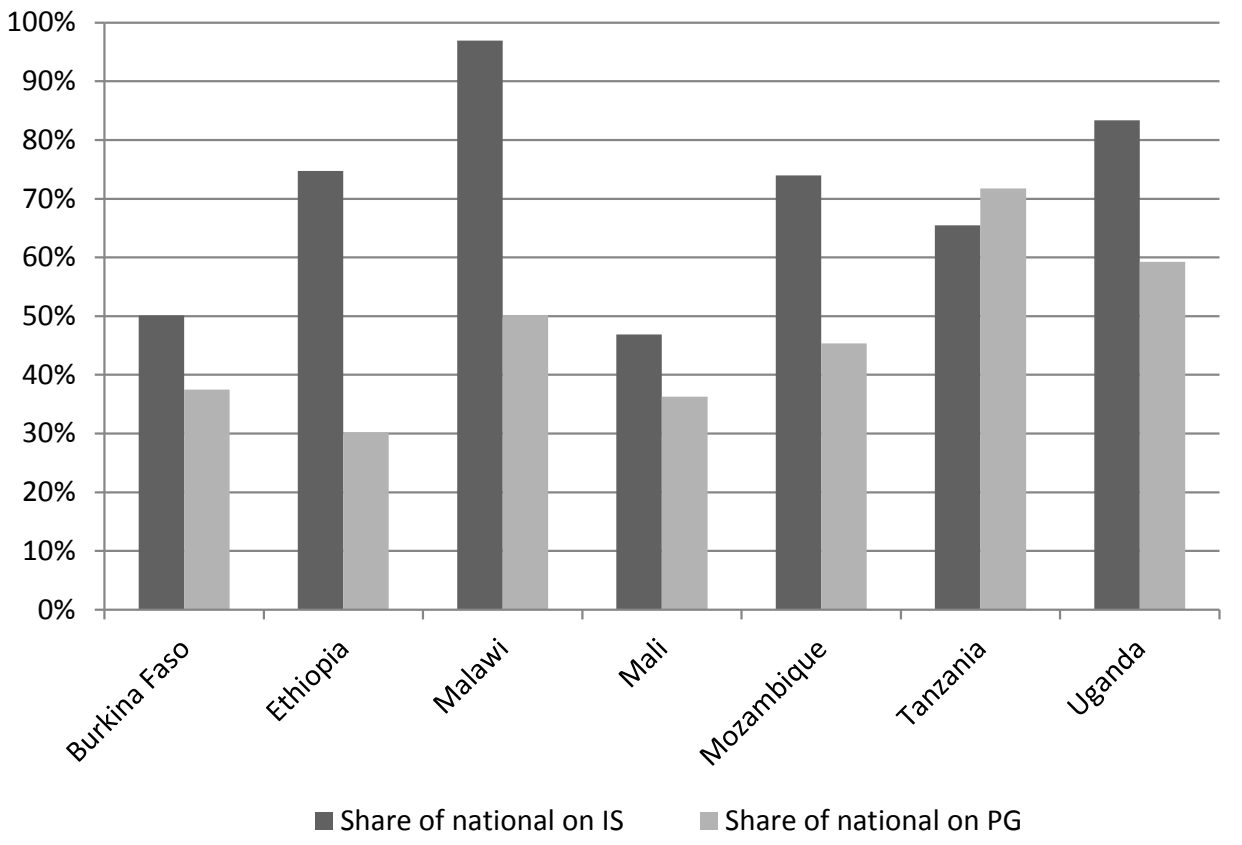

Source: The authors.

It is also possible to look at the budget execution rate of input subsidies depending on whether they are funded by donors or not and across categories of interest. It seems relatively more difficult for governments to execute budget resources allocated to input subsidies than those dedicated to ARE or KDE (Annex 4.6.4). However, the differential between the execution rate of national AIE and agricultural-specific expenditures without AIE is bigger in absolute value than the same differential taken for input subsidies. Hence, input subsidies do not seem to be the most difficult expenditure category for governments to execute.

Nevertheless, the national execution rates for input subsidies have been dwindling over the period, while donor execution rates, despite being lower, remained stable between 2006 and 2012 and even

\footnotetext{
${ }^{41}$ Ghana and Kenya were removed from the dataset for the analysis of the role of aid, as due to data availability constraints, the expenditure data for these two countries omits a substantial portion of national and donor expenditures, respectively (FAO, 2014b, 2015a).
} 
increased in 2013 (Figure 16). This suggests that national governments are facing increasing difficulties in executing the budgeted amounts for input subsidies. ${ }^{42}$

Figure 16: Average execution rates for input subsidies, donor and national expenditures, for seven African countries, 2006-13, in $\%{ }^{43}$

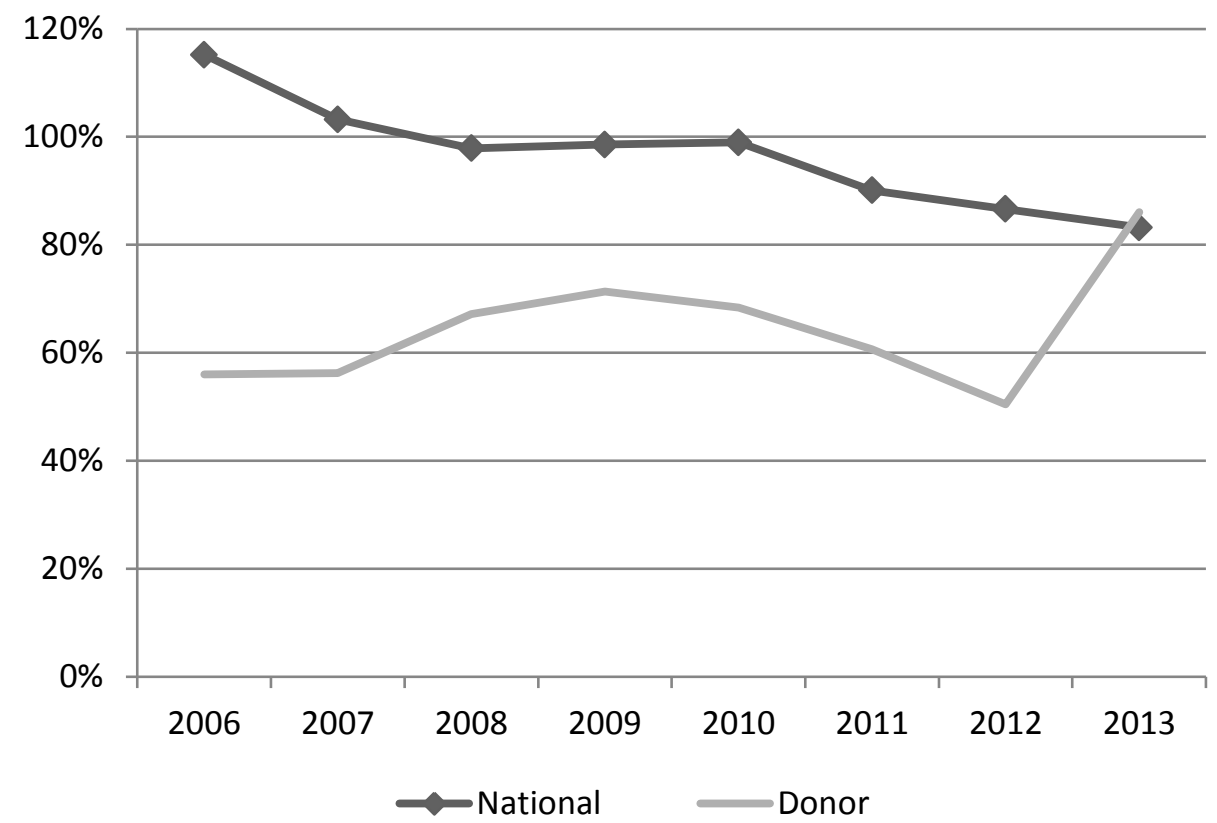

Source: The authors.

\subsection{Discussion and conclusion}

At this point, it seems useful to relate the results presented in this paper to the existing literature on the topic and try to shed light on two broad questions flowing from this discussion: (i) How can the inertia of the share of expenditure in support of input subsidies relative to the overall agricultural public expenditures be explained; (ii) how could the efficiency and/or effectiveness of expenditure devoted to input subsidies be increased?

We believe that our results are generally in line with and add new information to the literature. The main findings can be summarized as follows.

Although a substantial share of agricultural-specific expenditures were dedicated to input subsidies over the 2006-2013 period in the African countries covered in this study, wide variations in the level and composition of these expenditures can be observed. While Ethiopia, Kenya and Uganda dedicated between 13 and $25 \%$ of their agricultural-specific expenditures to input subsidies, Burkina Faso, Mali, Mozambique and the United Republic of Tanzania had shares fluctuating between 31 and $71 \%$. Malawi positions itself as an outlier, having allocated almost three-quarters of its agricultural-specific expenditures to input subsidies over the period. Despite this variety, input subsidies share the tendency of getting stuck in agricultural budgets. Their relative size tends to remain stable over time.

\footnotetext{
${ }^{42}$ It is also possible to look at the evolution of donor and national execution rates for ARE, KDE and AIE. Doing so shows that over the reviewed period, the difficulty of executing budgeted resources has increased more for input subsidies that for other categories of spending. Indeed, the average growth rate of national execution rates for 2006-13 of input subsidies, ARE, KDE and AIE was of -4,-2, 4 and $1 \%$, respectively.
}

${ }^{43}$ Ghana and Kenya are not included (see note 41 ). 
In addition, maintaining expenditures on input subsidies can happen to the expense of other expenditure categories. As shown in this study, spending on knowledge dissemination exhibits a decreasing trend in the nine countries under review. Further, our results suggest that input subsidies exhibit sub-optimal budget execution rates.

Finally, although this is not one of their distinctive features - expenditures allocated to knowledge dissemination activities or to agricultural infrastructures behave similarly -, execution rates for expenditures allocated to input subsidies originating from national sources have declined over the period under review, which echoes the difficulty of implementing such expenditure measures.

As a result of this work, we believe two main myths should be nuanced. First, contrary to what is often implicitly discussed in the literature, agricultural public expenditure in SSA are not always strongly biased towards input subsidies. The only country in our sample that spends more than 50 percent of its budget on inputs subsidies is Malawi, a country that should not be seen as a representative country but rather as a specific case. Second, most studies have equated input subsidies with variable input subsidies on seeds and fertilizers while our results show that spending classified as input subsidies is much more diversified and includes investment in capital, for irrigation for example, or human capital, through extension services and training for example.

Regarding the efficacy and/or efficiency of input subsidies, the literature offers a diversity of views depending on the way these subsidies are designed and implemented (Morris et al., 2007; Minot and Benson, 2009; Druilhe and Barreiro-Hurlé, 2012). For some authors, probably the majority, the lasting pre-eminence of input subsidies in agricultural budgets can be seen as a problem. They are generally considered too costly, with dubious benefits. Indeed, there is a broad consensus that, unlike input subsidies, public investment on agricultural research and infrastructure has a strong and long-term positive effect on agricultural productivity (Binswanger et al., 1993; Estache et al., 2005; PinstrupAndersen and Shimokawa, 2006; Fan and Zhang, 2008). In addition, the inert weight of input subsidies in the countries' budget can be considered a source of inefficiency in itself, as it prevents spending in other categories that have been deemed essential in many agricultural development strategies. This is referred to the crowding out effect of input subsidies (Jayne et al., 2013; Jayne and Rashid, 2013; Fan et al., 2008; Fan et al., 2009). Regarding the low execution rate of input subsidies, the evidence put forward in this paper echoes the concerns about the difficult implementation and management of input subsidy programmes (Baltzer, 2011). The fact that donor execution rates remained below national ones for the majority of the period under review is consistent with the overall pattern of public expenditures observed in countries that were analysed by MAFAP. Indeed, external funding tends to be poorly mainstreamed in national financial management systems, which in turn affects the ability of governments to effectively spend the money as was planned (FAO, 2014a). ${ }^{44} \mathrm{Hence}$, not only are input subsidies exhibiting a tendency to morph into recurrent expenditures over time and to receive relatively more attention from national governments than from donors; they are also proving more and more difficult to be efficiently funded.

Political economy arguments have often been invoked to explain the persistence of inputs subsidies in agricultural budgets. In the shortrun, policy makers have strong political incentives to provide funding in support of private goods whose benefits economically accrue to specific categories of agents and politically favour or reward specific fractions of the electorate at the expense of others. By contrast, public goods affect all agents indistinctively, which makes them less attractive from a policy maker's point of view especially just before or right after an election (Bates, 1981; Poulton, 2012). The fact that donors tend to invest more in public goods than in private goods in the countries reviewed here

\footnotetext{
${ }^{44}$ Average donor execution rates are below national ones also for ARE, KDE and AIE.
} 
supports the political economy argument. In addition, for agents in the sector, getting a better access to private goods is a tangible sign of political action which is expected to provide benefits in the short run. On the contrary, the positive impact of spending on infrastructures or research will typically take time to materialize.

However, other authors also recall that there are reasons for the existence of input subsidy programs that are not just self-interest and political. For example, in presence of important rural input market failures, as is often the case in Sub-Saharan Africa, governments have no choice but to intervene to replace or modify the market to help smallholders access the input they need. At the same time, there seems to be consensus in the literature on the need for governments' interventions to target the small farmers who face insurmountable market failures (Wiggins and Brooks, 2010).

Regardless of findings, positions or preferences expressed in the literature, it appears unlikely that input subsidies will be unilaterally discontinued. It is therefore suggested they be treated with pragmatism. So, the second question arises on how to improve existing and future input subsidy schemes?

In this regard, one should note that fiscal policies cannot be considered in isolation with respect to other public policies. For example, moving towards smaller spending on input subsidies and higher spending on agricultural research and knowledge dissemination will only be beneficial if producers are located in an enabling market environment. One could hardly expect enhanced agricultural growth to be reached by reducing input subsidies and providing research and technical assistance if producers continue to perceive prices that are too low, possibly due to substantial market failures, inefficient markets, and/or distortive economic policies (FAO, 2015b; 2015c). In this case, a smooth transition should be ensured by simultaneously working on market quality but also through PEA interventions on, for example, infrastructures and marketing. Moreover, policy advocacy work surely needs to put the emphasis on curbing this category of public spending and increasing its overall effectiveness. This would imply enhancing the transparency and accountability of budgetary decisions, improving policy coherence with other policy objectives and measures and systematizing the targeting of beneficiaries. The latter is crucial to primarily support those small farmers that struggle to access inputs and are likely to experience a significant productivity increase if supported. Such practices are to be seen as a first practical step forward in the process towards more efficient and effective agricultural budget management in SSA. 


\subsection{References}

Adams, R.H. Jr. (2000) The Politics of Economic Policy Reform in Developing Countries. World Bank Policy Research Working Paper 2443. Washington, DC: World Bank.

Akyüz, Y. and Gore, C. (2001) African Economic Development in a Comparative Perspective, Cambridge Journal of Economics, vol. 25, n³, May, pp. 265-88.

Allen, S. and Qaim, M. (2012) Agricultural Productivity and Public Expenditures in Sub-Saharan Africa. Discussion Paper Series, 01173. Washington, DC: International Food Policy Research Institute.

Anderson, K. (2010) (ed.) The Political Economy of Agricultural Price Distortions. Cambridge: Cambridge University Press.

Anderson, K. and Masters, W. (2009) Distorsions to Agricultural Incentives in Africa. World Bank. Washington, DC: World Bank.

AU. (2014) Malabo Declaration on Accelerated Agricultural Growth and Transformation for Shared Prosperity and Improved Livelihoods. Paper from the Twenty-Third Ordinary Session of the Assembly of the African Union, June 2014, Malabo, Equatorial Guinea. Addis Ababa, Ethiopia.

Baltzer, K. (2011) Agricultural Input Subsidies in Sub-Saharan Africa. Evaluation Study. Ministry of Foreign Affairs of Denmark. Danish International Development Agency.

Bates, R. (1981) Markets and States in Tropical Africa : The Political Basis Of Agricultural Policies. Berkeley, CA, University of California Press.

Benin, S. and Binswanger-Mkhize, P. (2012) The Political Economy of Agricultural Incentives and Public Expenditures, with Special Reference to Africa. Conference Working Paper 20, Prepared for the ASTIIFPRI/FARA Conference, Accra Ghana, December 5-7, 2011. Washington, DC: International Food Policy Research Institute.

Benin, S.; Mogues, T.; Cudjoe, G. and Randriamamonjy, J. (2009) Public Expenditures and Agricultural Productivity Growth in Ghana. Contributed Paper, International Association of Agricultural Economists, 2009 Conference, Beijing.

Benin, S.; Nin-Pratt, A.; Fan, S.; Breisinger, C.; Mogues, T.; Thurlow, J. and Diao, X. (2008) Growth and Poverty Reduction Impacts of Public Investments in Agriculture and Rural Areas. ReSAKSS Working Paper, 7.

Binswanger, H.P., Khandker, S.R., Rosenzweig, M.R. (1993) How Infrastructure and Financial Institutions Affect Agricultural Output and Investment in India. Journal of Development Economics 41:337-366.

Booth, D. (2011) Aid, Institutions and Governance: What Have We Learned? Development Policy Review, 29

Booth, D., Golooba-Mutebi, F. (2014) How the International System Hinders the Consolidation of Developmental Regimes In Africa. Developmental Regimes in Africa. Working Paper. January 2014.

Cabral, L., Scoones, I. (2006) Narratives of Agricultural Policy in Africa: What Role for Ministries of Agriculture ? Future Agricultures, Research Paper 001. March 2006. Available at : http://www.future- 
agricultures.org/publications/research-and-analysis/research-papers/180-narratives-of-agriculturalpolicy-in-africa-what-role-for-ministries-of-agriculture/file (visited on September 10, 2015).

Chinsinga, B., (2012) Deconstructing the Success Myth: A Case of the Malawi Farm Input Subsidy Programme (FISP). Instituto de Estudos Sociais e Economicos. Conference paper 11. Available at : http://www.iese.ac.mz/lib/publication/III Conf2012/IESE IIIConf Paper11.pdf (visited on September 10, 2015).

Diao, X., Hazell, P. and Thurlow, J. (2010) The Role of Agriculture in African Development. World Development. Volume 38, Issue 10. October 2010, Pages 1375-83.

Diao, X.; Hazell, P.; Resnick, D. and Thurlow, J. (2007) The Role of Agriculture in Development: Implications for Sub-Saharan Africa. IFPRI Research Report 153, Washington, DC: International Food Policy Research Institute.

Dorward, A.; Fan, S.; Kydd, J.; Lofgren, H.; Morrison, J.; Poulton, C.; Rao, N.; Smith, L.; Tchale, H.; Thorat, S.; Urey I. and P. Wobst (2004) Institutions and Policies for Pro-poor Agricultural Growth, Development Policy Review, 22 (6), pp. 611-22. London: Overseas Development Institute.

Druilhe, Z. and Barreiro-Hurlé, J. (2012) Fertilizer Subsidies in Sub-Saharan Africa. ESA Working paper No. 12-04. Rome, Food and Agriculture Organization of the United Nations.

Estache, A., Speciale, B. and Veredas, D. (2005) How Much Does Infrastructure Matter to Growth in Sub-Saharan Africa? World Bank Working Paper. Washington, DC: World Bank.

Fan, S. and Zhang, X. (2008) Public Expenditure, Growth and Poverty Reduction in Rural Uganda. African Development Review, 20(3), 466-496.

Fan S., Gulati, A. and Thorat, S. (2008) Investment, Subsidies, and Pro Poor Growth in Rural India. Agricultural Economics. 39(2): 163-70.

Fan, S., and Rao, N. (2003) Public Spending in Developing Countries: Trends, Determination, and Impact. EPTD Discussion Paper, 99. Washington, DC: International Food Policy Research Institute.

Fan, S., Mogues, T., and Benin, S. (2009) Setting Priorities for Public Spending for Agricultural and Rural Development in Africa. Policy Brief. Washington, DC: International Food Policy Research Institute.

FAO. (2015a) Analysis of Public expenditure in support of Food and Agriculture in Kenya, 2006-12. Technical notes series, MAFAP, by Laibuni, NM, Mathenge, N, Kirui, L, Omiti, J. O. Rome: Food and Agriculture Organization of the United Nations.

FAO. (2015b) Analysis of Price Incentives for Maize in Ethiopia. Technical notes series, MAFAP, by Wakeyo M.B., Lanos B. Rome: Food and Agriculture Organization of the United Nations.

FAO. (2015c) Analysis of Price Incentives for Tea in Malawi. Technical notes series, MAFAP, by Cameron, A., Mkomba, F. Rome: Food and Agriculture Organization of the United Nations.

FAO. (2015d) MAFAP Database on Public Expenditure on Food and Agriculture. Available on: http://www.fao.org/in-action/mafap/database/en/ (visited on September 10, 2015).

FAO. (2015e) MAFAP Methodology Working paper: Volume II. Analysis of Public Expenditure on Food and Agriculture. MAFAP Technical Notes Series. Rome: Food and Agriculture Organization of the United Nations. 
FAO. (2014a) Public Expenditures in Support of Food and Agriculture Development in the Federal Republic of Ethiopia, 2006/7-2012/3: A preliminary assessment. Technical notes series, MAFAP, by Lanos, B., Mas Aparisi A.and Woldeyes, F. Rome: Food and Agriculture Organization of the United Nations.

FAO. (2014b) Analysis of Public Expenditure in Support of the Food and Agriculture Sector in Ghana, 2006-2012: A preliminary assessment. Technical notes series, MAFAP, by Ghins, L., Rome: Food and Agriculture Organization of the United Nations.

FAOSTAT. (2015) FAOSTAT Database. Statistics Division. Rome : Food and Agriculture Organization of the United Nations. Available at: http://faostat3.fao.org/ (visited on September 10, 2015).

Jayne, T.S. and S. Rashid. (2013) Input Subsidy Programs in sub-Saharan Africa: a Synthesis of Recent Evidence. Agricultural Economics 44:547-62

Jayne, T.S.; Mather, D.; Mason, N. and Ricker-Gilbert, J. (2013) How do Fertilizer Subsidy Programs Affect Total Fertilizer Use? A Synthesis of the Evidence on "Crowding in/out" in Sub-Saharan Africa. Agricultural Economics 44(6):687-703.

Jayne, T. S.; Govereh, A.J.; Mwanaymo, J.; Nyoro, K. and Chapoto, A. (2002) False Promise or False Premise? The Experience of Food and Input Market Reform in Eastern and Southern Africa, World Development, Vol. 30, No. 11, pp. 1967-1985.

Komorowska, J. (2010) A Proposed Methodology for Measuring Government Expenditures in Support of Food and Agriculture Sector Development and Application in the Case of Uganda. Paper presented at the Global Forum on Agriculture, 29-30 November 2010, Paris, Organisation of Economic Cooperation and Development headquarters.

Krueger, A. (1990) Government failures in development, Journal of Economic Perspectives, Volume 4, Number 3 -Summer, pp. 9-23.

Mas Aparisi, A., Ghins, L. and Balié, J. (2015) Initiatives for the Monitoring and Analysis of Agricultural Public Expenditure in Africa. A Comparative Review and Analysis. Rome: Food and Agriculture Organization of the United Nations.

Mason, N., Jayne, T. and Walle, N., (2013) Fertilizer Subsidies and Voting Patterns: Political Economy Dimensions of Input Subsidy Programs. Agricultural and Applied Economics Association, 2013 annual meeting. Available at http://purl.umn.edu/149580 (visited on September 10, 2015).

Minot, N. and Benson T. (2009) Fertilizer Subsidies in Africa: Are Vouchers the Answer? IFPRI Issue Brief 60. Washington, DC: International Food Policy Research Institute.

Mogues, T.; Yu, B.; Fan, S. and McBride, L. (2012) The Impacts of Public Investment in and for Agriculture Synthesis of the Existing Evidence. IFPRI Discussion Paper, 01217. Washington, DC : International Food Policy Research Institute.

Mogues, T., Ayele, G. and Zelekawork, P. (2009) The Bang for the Birr, Public Expenditures and Rural Welfare in Ethiopia. IFPRI Research Report, 160. Washington, DC: International Food Policy Research Institute.

Morris, M.; Kelly, V.A.; Kopicki, R. and Byerlee, D. (2007) Promoting Increased Fertilizer Use in Africa: Lessons Learned and Good Practice Guidelines. Washington, DC: World Bank. 
Moss, Todd J., Pettersson, G. and Van de Walle, N. (2006) An Aid-Institutions Paradox? A Review Essay on Aid Dependency and State Building in Sub-Saharan Africa. January 2006. Centre for Global Development Working Paper No. 74; Mario Einaudi Centre for International Studies Working Paper No. 11-05.

OECD. (2010) OECD's Producer Support Estimate and Related Indicators of Agricultural Support Concepts, Calculations, Interpretation and Use (The PSE Manual). Paris: Organisation for Economic Cooperation and Development.

Pinstrup-Andersen, P. and Shimokawa, S. (2006) Rural Infrastructure and Agricultural Development. Paper prepared for presentation at the Annual Bank Conference on Development Economics, Tokyo, Japan, May 29-30, 2006.

Poulton, C. (2014) Democratisation and the Political Incentives for Agricultural Policy in Africa. Development Policy Review, 32: s101-s122. Doi: 10.1111/dpr.12078.

Poulton, C. (2012) Democratisation and the Political Economy of Agricultural Policy in Africa. Future Agricultures Consortium Working Paper n. 43, Brighton, UK.

Ricker-Gilbert, J.; Mason, N.; Jayne, T.; Darko, F. and Tembo, S. (2013) What are the Effects of Input Subsidy Programs on Equilibrium Maize Prices? Evidence from Malawi and Zambia. Selected Paper prepared for presentation at the Agricultural and Applied Economics Association's 2013 AAEA \& CAES Joint Annual Meeting, Washington, DC, August 4-6, 2013.

Shively, G.E. and Ricker-Gilbert, J. (2013) Measuring the Impacts of Agricultural Input Subsidies in SubSaharan Africa: Evidence from Malawi's Farm Input Subsidy Program. Global Policy Research Institute (GPRI) Policy Briefs: Vol. 1: Iss. 1, Article 4. Available at: http://docs.lib.purdue.edu/gpripb/vol1/iss1/4 (visited on September 10, 2015).

UN. (2014). The Millennium Development Goals Report 2014. New York, USA. Available at: http://www. Un.org/en/development/desa/publications/mdgreport-2014.html (visited on September 10, 2015).

WDI. (2015) Word Development Indicators Database. Washington, DC: World Bank. Available at: http://data.worldbank.org/data-catalog/world-development-indicators (visited on September 10, 2015).

Weeks, J. (2010). Why Monetary Policy is Irrelevant in Africa South of the Sahara. Centre for Development Policy and Research. School of Oriental and African Studies. Development Viewpoint. Number 53. June 2010. Available at: https://www.soas.ac.uk/cdpr/publications/dv/file59766.pdf (visited on September 10, 2015).

Wiggins, S. (2014) African Agricultural Development: Lessons and Challenges. Journal of Agricultural Economics, 65: 529-56. Doi: 10.1111/1477-9552.12075

Wiggins, S. and Brooks, J. (2010). The Use of Input Subsidies in Developing Countries. Global Forum on Agriculture. 29-30 November 2010. Policies for Agricultural Development, Poverty Reduction and Food Security. Paris: Organisation for Economic Co-operation and Development headquarters.

World Bank. (2011) Practitioner's toolkit for agriculture public expenditure analysis. Washington, DC: World Bank.

World Bank. (2007) World Development Report 2008: Agriculture for Development, Washington, DC: World Bank. 


\subsubsection{MAFAP classification of public expenditures in support of the food and agricultural sector $^{45}$}

1. Agriculture-specific expenditure - monetary transfers that are specific to the agricultural sector, i.e. agriculture is the only, or principal, beneficiary of a given expenditure measure

1.1 Payments to agents in the food and agriculture sector - monetary transfers to individual agents in the food and agriculture sector

1.1.1 Payments to producers - monetary transfers to individual agricultural producers (farmers)

A. Production subsidies based on outputs - monetary transfers to agricultural producers that are based on current output of a specific agricultural commodity

B. Input subsidies - monetary transfers to agricultural producers that are based on on-farm use of inputs:

B1 - Variable inputs (seeds, fertiliser, energy, credit, other) - monetary transfers reducing the on-farm cost of a specific variable input or a mix of variable inputs

B2 - Capital (machinery and equipment, on-farm irrigation, other basic on-farm infrastructure) - monetary transfers reducing the on-farm investment cost of farm buildings, equipment, plantations, irrigation, drainage and soil improvements

B3 - On-farm services (pest and disease control/veterinary services, on-farm training, technical assistance, extension etc., other) - monetary transfers reducing the cost of technical assistance and training provided to individual farmers

C. Income support - monetary transfers to agricultural producers based on their level of income

D. Other payments to producers - monetary transfers to agricultural producers individually for which there is insufficient information to allocate them into the above listed categories

1.1.2 Payments to consumers - monetary transfers to final consumers of agricultural commodities individually in the form of:

E. Food aid - monetary transfers to final consumers to reduce the cost of food

F. Cash transfers - monetary transfers to final consumers to increase their food consumption expenditure

G. School feeding programmes - monetary transfers to final consumers to provide free or reduced-cost food in schools

H. Other payments to consumers - monetary transfers to final consumers individually for which there is insufficient information to allocate them into the above listed categories

1.1.3 Payments to input suppliers - monetary transfers to agricultural input suppliers individually

1.1.4 Payments to processors - monetary transfers to agricultural commodities processors individually

1.1.5 Payments to traders - monetary transfers to agricultural traders individually

1.1.6 Payments to transporters - monetary transfers to agricultural commodities transporters individually

1.2 General support to the food and agriculture sector- public expenditures generating monetary transfers to agents of the agrofood sector collectively

I. Agricultural research - public expenditures financing research activities improving agricultural production

J. Technical assistance - public expenditures financing technical assistance for agricultural sector agents collectively

K. Training - public expenditures financing agricultural training

L. Extension/technology transfer - public expenditures financing provision of extension services

M. Inspection (veterinary/plant) - public expenditures financing control of quality and safety of food, agricultural inputs and the environment

N. Agricultural infrastructure- public expenditures financing off-farm collective infrastructure

${ }^{45}$ The table is taken from MAFAP, 2015a, p. 6-7. Itself, the table was based on the classification proposed in Komorowska, 2010. 
N1. Feeder roads - public expenditures financing feeder roads

N2. Off-farm irrigation - public expenditures financing off-farm irrigation off-farm irrigation

N3. Other off-farm infrastructure - public expenditures financing agricultural infrastructure that are not feeder roads or

O. Storage/public stockholding - public expenditures financing public storage of agro-food products

P. Marketing - public expenditures financing assistance in marketing of food and agriculture products

Q. Other general support to the food and agriculture sector - other transfers to the agro-food agents collectively for which there is insufficient information to allocate them into above listed categories

2. Agriculture-supportive expenditure - public expenditures that are not specific to agriculture, but which have a strong influence on agricultural sector development

R. Rural education - public expenditures on education in rural areas

S. Rural health - public expenditures on health services in rural areas

T. Rural infrastructure - public expenditures on rural infrastructure

T1. Rural roads - public expenditures financing rural roads

T2. Rural water and sanitation - public expenditures financing rural water and sanitation

T3. Rural energy - public expenditures financing rural energy

T4. Other rural infrastructure - public expenditures financing rural infrastructure that are not rural roads, rural water and sanitation, rural energy and other rural infrastructure

U. Other support to the rural sector - other public expenditures on rural areas benefiting agricultural sector development for which there is insufficient information to allocate them into above listed categories

Total expenditure in support of the food and agriculture sector (excluding administrative costs) (policy transfers, PEAPT): sum of agriculture-specific and agriculture-supportive expenditure $(1+2)$

Identifiable administrative costs for the food and agriculture sector: administrative costs include costs of formulation, implementation and evaluation of agricultural policies

Total expenditure in support of the food and agriculture sector (including administrative costs) (PEA): sum of agriculture-specific expenditure, agriculture supportive expenditure and identifiable administrative costs for the food and agriculture sector (1+2+identifiable administrative costs for the food and agriculture sector). 
4.6.2 Gaps in PEA time series, per country

Table 9: Missing years in the PEA time series used for the analysis.

\begin{tabular}{ll}
\hline Country & Missing years within the 2006-2013 period \\
\hline Burkina Faso & None \\
Ethiopia & 2013 \\
Ghana & 2013 \\
Kenya & 2006,2013 \\
Malawi & None \\
Mali & 2013 \\
Mozambique & $2006,2007,2008$ \\
United Republic of Tanzania & 2006 \\
\hline Uganda & 2006 \\
\hline
\end{tabular}

Source: The authors. 
4.6.3 Data description

Table 10: Description of the data series used in the analysis.

\begin{tabular}{|c|c|c|c|}
\hline \multicolumn{2}{|c|}{ Categories of PEA } & \multirow[t]{2}{*}{ Unit } & \multirow[t]{2}{*}{ Source } \\
\hline Input subsidies & & & \\
\hline Input subsidies, total & Constant 2011 USD & MAFAP, 2015b & Spending on total input subsidies is MAFAP category $\mathrm{B}$, the sum of $\mathrm{B} 1, \mathrm{~B} 2$ and $\mathrm{B} 3$ \\
\hline Variable inputs & Constant 2011 USD & MAFAP, 2015b & Spending on variable inputs (seeds, fertilizers, etc.) is MAFAP category B1 \\
\hline Capital & Constant 2011 USD & MAFAP, 2015b & Spending on capital (machinery and equipment, on-farm irrigation, etc.) is MAFAP category B2 \\
\hline On-farm assistance & Constant 2011 USD & MAFAP, $2015 b$ & $\begin{array}{l}\text { Spending on on-farm assistance (pest and disease control, veterinary services, on-farm training, technical } \\
\text { assistance, extension,...) is MAFAP category B3 }\end{array}$ \\
\hline \multicolumn{4}{|l|}{$\begin{array}{l}\text { Agricultural research and } \\
\text { knowledge dissemination }\end{array}$} \\
\hline Agricultural research & Constant 2011 USD & MAFAP, 2015b & Spending on agricultural research is MAFAP category I \\
\hline Knowledge dissemination & Constant 2011 USD & MAFAP, 2015b & $\begin{array}{l}\text { Spending on knowledge dissemination was taken as the sum of MAFAP categories J (technical assistance), } \mathrm{K} \\
\text { (training) and L (extension) }\end{array}$ \\
\hline \multicolumn{4}{|l|}{ Infrastructures } \\
\hline $\begin{array}{r}\text { Agricultural } \\
\text { infrastructures }\end{array}$ & Constant 2011 USD & MAFAP, 2015b & Spending on agricultural infrastructures is MAFAP category N \\
\hline \multicolumn{4}{|l|}{$\begin{array}{l}\text { Other series used for the } \\
\text { analysis }\end{array}$} \\
\hline Exchange rates & $\begin{array}{l}\text { Local currency } \\
\text { unit/USD }\end{array}$ & WDI, 2015 & \\
\hline Number of farms & Number of farms & WDI, 2015 & $\begin{array}{l}\text { Yearly rural population figures were taken from WDI, 2015. From these series, the number of farms in each } \\
\text { country for each year was computed by assuming } 6 \text { dependents per farm }\end{array}$ \\
\hline Agricultural GDP & Constant 2011 USD & WDI, 2015 & $\begin{array}{l}\text { The "Agriculture, value added (current LCU)" series was taken on WDI, } 2015 \text { and then converted into constant } \\
2011 \text { USD by multiplying the amounts for each year by the } 2011 \text { LCU/USD exchange rate. }\end{array}$ \\
\hline GDP & Constant 2011 USD & WDI, 2015 & $\begin{array}{l}\text { The "GDP (current LCU)" series was taken on WDI, } 2015 \text { and then converted into constant } 2011 \text { USD by multiplying } \\
\text { the amounts for each year by the } 2011 \text { LCU/USD exchange rate. }\end{array}$ \\
\hline
\end{tabular}

Source: The authors. 
Table 11: Differential between the execution rates (ER) of input subsidies (IS), agricultural research expenditure (ARE), knowledge dissemination expenditure (KDE) and agricultural infrastructure expenditure (AIE) and the execution rates of agricultural-specific expenditure without said categories by funding source, in nine African countries, average over the $2006-2013$ period, in \%

\begin{tabular}{|c|c|c|c|c|c|c|c|c|c|c|c|c|}
\hline & \multicolumn{3}{|c|}{ Differential ER IS/non IS } & \multicolumn{3}{|c|}{ Differential ER ARE/non ARE } & \multicolumn{3}{|c|}{ Differential ER KDE/non KDE } & \multicolumn{3}{|c|}{ Differential ER AIE/non AIE } \\
\hline & Donor & National & Total & Donor & National & Total & Donor & National & Total & Donor & National & Total \\
\hline Burkina Faso & $-9 \%$ & $4 \%$ & $-2 \%$ & $19 \%$ & $1 \%$ & $18 \%$ & $-3 \%$ & $-6 \%$ & $-8 \%$ & $-4 \%$ & $-5 \%$ & $-9 \%$ \\
\hline Ethiopia & $-43 \%$ & $1 \%$ & $-14 \%$ & $-27 \%$ & $-2 \%$ & $-16 \%$ & $2 \%$ & $2 \%$ & $1 \%$ & $10 \%$ & $-21 \%$ & $8 \%$ \\
\hline Ghana & $37 \%$ & NA & $37 \%$ & $2 \%$ & NA & $-1 \%$ & $-6 \%$ & NA & $-8 \%$ & $-11 \%$ & NA & $2 \%$ \\
\hline Kenya & NA & $-18 \%$ & $-22 \%$ & NA & $8 \%$ & $14 \%$ & NA & $11 \%$ & $12 \%$ & NA & $20 \%$ & $25 \%$ \\
\hline Malawi & $5 \%$ & $3 \%$ & $29 \%$ & $89 \%$ & $-14 \%$ & $1 \%$ & $62 \%$ & $-2 \%$ & $-8 \%$ & $-19 \%$ & $-47 \%$ & $-60 \%$ \\
\hline Mali & $4 \%$ & $4 \%$ & $7 \%$ & $6 \%$ & $-8 \%$ & $-1 \%$ & $1 \%$ & $-10 \%$ & $-6 \%$ & $-2 \%$ & $-4 \%$ & $-4 \%$ \\
\hline Mozambique & $-14 \%$ & $-1 \%$ & $2 \%$ & $8 \%$ & $0 \%$ & $3 \%$ & $3 \%$ & $-3 \%$ & $-11 \%$ & $-6 \%$ & $0 \%$ & $-4 \%$ \\
\hline $\begin{array}{l}\text { United Republic of } \\
\text { Tanzania }\end{array}$ & $28 \%$ & $-31 \%$ & $-20 \%$ & $-9 \%$ & $16 \%$ & $13 \%$ & $-16 \%$ & $17 \%$ & $12 \%$ & $-25 \%$ & $-2 \%$ & $-12 \%$ \\
\hline Uganda & $-3 \%$ & $9 \%$ & $13 \%$ & $5 \%$ & $4 \%$ & $1 \%$ & $-7 \%$ & $7 \%$ & $1 \%$ & $-1 \%$ & $-23 \%$ & $-17 \%$ \\
\hline Average & $1 \%$ & $-4 \%$ & $3 \%$ & $12 \%$ & $1 \%$ & $4 \%$ & $5 \%$ & $2 \%$ & $-2 \%$ & $-7 \%$ & $-10 \%$ & $-8 \%$ \\
\hline $\begin{array}{l}\text { Average without } \\
\text { Malawi }\end{array}$ & $0 \%$ & $-5 \%$ & $0 \%$ & $0 \%$ & $3 \%$ & $4 \%$ & $-4 \%$ & $2 \%$ & $-1 \%$ & $-6 \%$ & $-5 \%$ & $-1 \%$ \\
\hline
\end{tabular}

Note: The expenditure data for Ghana and Kenya omits a substantial portion of national and donor expenditures, respectively (FAO, 2014b, 2015a). Therefore, the execution rates for these countries and funding sources were not included in the table.

Source: The authors. 


\section{Price signals and supply responses for staple food crops in Sub Saharan countries ${ }^{46}$}

\subsection{Introduction}

Despite the wave of agricultural policy reforms carried out in Sub-Saharan Africa (SSA) during the last decades, the lack of results in terms of productivity and growth has been attributed - among other factors - to a weak or absent supply response to market signals (Di Marcantonio et al, 2014). During the 1960s and 1970s, some authors argue that this is particularly true for staple food crops because the marketing systems are less developed and production is mainly devoted to on-farm consumption, making price incentives of limited relevance for farmers' decisions. Most governments in SSA used the argument that subsistence farmers do not respond to market signals and run a static business to justify an excessive taxation of the sector in favour of pro-urban and industry-oriented policies (Bates, 1983; World Bank, 2008). The rationale was that taxing agriculture would make additional resources available to be invested in other sectors without substantially slowing down overall growth (Helleiner, 1975; Askari and Cummings, 1977; Krueger, Schiff, and Valdes, 1991; Schiff and Montenegro, 1997; McKay et al., 1998; Anderson and Masters, 2009).

Since the 1980s and 1990s, governments eventually reduced the anti-agricultural bias (Anderson and Masters, 2009). Concomitantly, the assumption that farmers' supply response is generally absent or very low has been less widely accepted as the literature has showed repeatedly that farmers including smallholders do react to price signals. Yet the argument is still attracting some degree of controversy in the academia as well as in policymaking circles (Townsend, 1999; Haile et al. 2015).

The focus of research evolved over time and shifted towards understanding which internal and external factors limit the supply response to price incentives (Clover, 2003; Svendsen et al, 2007; Pratt and $\mathrm{Yu}, 2008$ ). A consensus emerges around two points: i) the aggregate short-run supply response is quite inelastic, and ii) the supply response for individual crops is less inelastic than the aggregate because production factors can be easily moved across crops (Onal, 2012). In most cases, authors analyzed price elasticity with respect to either aggregate agricultural supply or individual cash crops, ignoring the specific case of staple food crops. These gaps in the literature can be explained by the lack of reliable and comparable cross-country data in SSA, especially for producer prices and marketing costs (Dawe et al., 2015).

Understanding if and how the food supply in SSA as a whole reacts to price signals constitutes a valuable piece of information for policymakers engaged in achieving food security in the region. In fact, even if subsistence agriculture might not be considered as a major driver of economic growth, it still has a crucial influence on the livelihoods of the most vulnerable sub-groups of the population (Poulton et al, 2006). Moreover, shedding more light on the relationship between price signals and food supply could help to enhance smallholder market participation in SSA and, hence, advance the development

\footnotetext{
${ }^{46}$ This paper is the result of a collaboration with two FAO colleagues, Emiliano Magrini and Cristian Morales Opazo, currently available as a Discussion Paper 1601 of the Department of Agricultural Economics and Rural Development of the University of Gottingen, ISSN 1865-2697 and submitted to the Journal of Agricultural Economics.
} 
agenda on what has been a priority topic for several decades (Barrett, 2008). Lastly, reliable information at regional level beyond the usual country-crop specific cases is needed to support better regionally integrated food markets in SSA in order for Africa to meet its own raising demand for food (World Bank, 2012).

To help fill some of these gaps, we analyze the supply response for major staple food crops in several SSA countries. To do that, we use a recent dataset produced by the "Monitoring and Analyzing Food and Agricultural Policies" (MAFAP) programme of the Food and Agriculture Organization (FAO) which provides detailed information on food crop prices, marketing costs and the effects of policy interventions for multiple value chains in ten SSA countries over the 2005-2013 period. In this study, we claim three contributions to the literature. First, to the best of our knowledge, this is the first attempt to perform a cross-country analysis of the price elasticity of supply in SSA focusing exclusively on staple food crops instead of cash crops or aggregate sector level production. Second, we exploit the richness of the MAFAP dataset to capture the different contribution of the direct incentives arising from i) domestic market intervention and border measures, ii) the monetary policies - especially those influencing the exchange rate - and iii) the border prices in the formulation of the farmers' price expectations and their relative impact on the supply response. Third, we demonstrate that estimates of the price elasticity of supply are biased when i) the wholesale price is used as proxy of the producer price; and ii) the marketing costs are omitted from the response function.

The results show that short-run price elasticity of supply is always positive and statistically significant, irrespective of the proxies used to measure the agricultural supply -acreage, production or yield - and the expected prices - farm-gate or wholesale - in the response function. This suggests that Sub-Saharan farmers are capable of interpreting market signals and responding positively to price increases for staple crops. In particular, we observe the highest response for production (0.59) while for yield and acreage, the price elasticity is substantially lower (i.e. 0.30 and 0.22 ). We also find that the supply responses are significantly influenced by marketing costs paid by farmers to commercialize their product and - not surprisingly - by past and current weather shocks. In comparison, the prices of competing commodities and the cost of inputs have less important effects. By decomposing the expected price into three components - the nominal coefficient of protection, the real exchange rate and the border price - we find that farmers in SSA respond to price signals arising primarily from shocks in the international market and from direct incentives resulting from border measures and government interventions in domestic markets. On the contrary, they are less stimulated by macroeconomic policies affecting the exchange rate.

The remainder of the paper is organized as follows. Section two introduces the methodology. Section three describes the dataset while section four presents the empirical strategy. Section five reports the results of the econometric exercise. Finally, section six concludes.

\subsection{Methodology}

Since the pioneering work of Nerlove (1956), economists have put a lot of efforts into investigating farmers' response to price signals. The agricultural supply response in Sub-Saharan Africa has historically been subject to much debate (Schiff and Montenegro, 1997; Onal, 2012) and most authors have primarily focused on explaining why the supply response in this region was generally low. However, isolating the main factors constraining the supply response has proved to be a difficult task (Baffes and Gardner, 2003). There is a certain consensus on the role of structural and institutional 
constraints (Kherallah et al., 2002) such as lack of complementary inputs, rural infrastructure, difficult access to credit, insufficient provision of extension services and lack of reliable insurance mechanisms (Binswanger et al., 1987; Key et al., 2000). In addition, authors like Bloom and Sachs (1998) argue that natural conditions such as low soil fertility and irregular rainfall further contribute to lower price elasticity of supply, especially in case of severe drought. Other empirical results suggest that an unstable political environment adversely influences food supply via production inefficiencies and attenuates competitiveness (Knack and Keefer, 1995; Keefer and Knack, 1997; Hall and Jones, 1997 and 1999).

Haile et al. (2015) propose a thorough and useful review of the literature providing an extensive range of methodological approaches and empirical strategies in a variety of settings for measuring agricultural supply response. To decide on the best method to adopt for our analysis, a number of conditions have to be considered. Most of the literature focuses on the analysis of the supply response for specific country-crop case studies (e.g. Bond, 1983; McKay et al., 1998; Baffes, 2003; Thiele, 2003; Leaver, 2004; Muchapondwa, 2009; Vitale et al., 2009; Molua, 2010; Mkpado, 2012) either at macro level (e.g. Thiele, 2003; Barr et al, 2009; Imai et al., 2011; Onal, 2012; Haile et al, 2014 and 2015) or at micro-level, i.e. plot, farm, and household (e.g. Lansink, 1999; Vitale et al, 2009; and Yu et al, 2012). Only a few authors provide cross-country estimates of the price elasticity of supply (e.g. Binswanger et al. 1987; Subervie 2008). For example, Onal's study (2012) proposes cross-country estimates of the price elasticity for SSA countries for export crops in Kenya, Mozambique, Tanzania, Uganda and Zambia. For our own study, we decide to perform a cross-country analysis of the supply response for staple food commodities which are fundamental in terms of food security in Sub-Saharan Africa, i.e. cereals, tuber and roots, and pulses.

To do that, we follow the standard model proposed by Nerlove (1956) based on the hypothesis that farmers partially adjust their output $(Q)$ towards a desired level $\left(Q^{*}\right)$ determined by an expected price $\left(\mathrm{P}^{*}\right)^{47}$. Unfortunately, neither $Q^{*}$ nor $\mathrm{P}^{*}$ are observable. In the literature, the preferred proxy for the desired output level is the acreage allocation because it is fully under farmers' control and it is not affected by exogenous shocks that occur after planting (e.g. Askari and Cummings, 1977; Chavas et al., 1983; Rao, 1989; Coyle, 1993; Vitale et al., 2009; Haile et al.,2015). However, the resulting price elasticity of supply can be considered a lower bound of the farmers' response to price signals because it does not capture the choices made between planting and harvesting (Rao, 1989; Oyejide, 1990; Haile et al., 2015). In this respect, to estimate the supply responses part of this literature employs not only acreage as an output proxy but also production and yield as complementary dependent variables (Braulke, 1982; Coyle, 1999; Weersink et al., 2010; Onal, 2012; Yu et al., 2012; Haile et al., 2015). We prefer to follow the latter approach, using all three proxies in estimating the supply response for the following reasons. First of all, the price elasticity estimates highly depend on the choice of the proxy (Rao, 1989), therefore combining a broader set of output measures will provide more robust estimates. Second, the possibility for farmers to adjust planted acreage is likely to be limited due to rigid patterns of land use which, in the case of staple food crops in SSA countries, are determined by subsistence needs and constraints on arable land availability (Askari and Cummings, 1977). Lastly, while the best estimator of farmers' production decisions is arguably planted acreage, we could only obtain data on harvested acreage which, if used alone, could reduce the accuracy of our results.

Choosing the proxy for the expected output price $\mathrm{P}^{*}$ is another crucial methodological consideration, which entails two different problems: a) choosing the price series that is actually driving the farmer

\footnotetext{
${ }^{47}$ Another common approach is to estimate the supply function derived from a profit maximizing framework with the joint estimation of output supply and input demand functions. However, this approach requires detailed information on all the input quantities and prices.
} 
decision and b) adopting the appropriate farmers' expectation hypothesis to determine which variable needs to be inserted in the empirical model. As pointed out by Askari and Cummings (1977), the researcher must select the price series which could support the best answer to the question: why would farmers produce more? If farmers do not market the crop they produce, then the price variable does not interest them. Nonetheless, if farmers seek to produce more it is usually to increase their income and be able to buy a broader range of goods. Hence, they will adjust their production decision looking at the price of their crop relative to those of other goods. Of course, in the literature on developing countries, the implicit assumption is that farmers want to increase the possibility of diversifying their consumption and are expected to react to changes in relative prices. These changes are usually captured by the crop price deflated by the consumer price index.

The literature on SSA countries estimates price elasticities of supply using - if available - the farm-gate price. The underlying assumption is that this price drives farmers' decisions. However, many exceptions have been made because it is generally difficult to assemble reliable producer price series in SSA countries (Dawe et al., 2015). As a consequence, most of the cross-country studies investigating the effect of price movements on agricultural supply have used less desirable variables such as the wholesale and retail prices or even the international price deflated by domestic price indexes. These are sub-optimal choices because farm-gate price and other domestic prices such as wholesale and retail behave differently in most SSA countries(Dawe et al., 2015), mainly due to incomplete price transmission along the domestic value chain (Meyer and von Cramon Taubadel, 2004). In the following sections, we show how using wholesale prices as a proxy for farm-gate prices biases the resulting price elasticity estimates.

For modelling farmers' price expectation, there are three well-known and widely applied hypotheses: a) naïve expectations (Ezekiel, 1938); b) adaptive expectations (Nerlove, 1958); and c) rational expectations. The first hypothesis assumes that prices do not change and the expected price is equal to the most recent observable one. The second hypothesis is also backward looking but assumes that farmers make adjustments in formulating price expectations in order to correct for past errors. Finally, the last hypothesis assumes that farmers efficiently use all the available information in predicting future prices. Following the Nerlove model, we assume adaptive expectations because they are more efficient than naïve expectations and more realistic than the rational expectations. For most farmers in SSA countries, accessing reliable, timely and up-to-date information on prices is problematic. Even if they have the opportunity to receive such market signals, they often lack the means to process them (Chavas, 2000 and Haile et al., 2015). The standard version of the Nerlovian partial adjustment model consists of the following functional forms:

$$
\begin{aligned}
& Q_{t}^{*}=a_{0}+a_{1} P_{t}^{*}+a_{2} X_{t}+\varepsilon_{t} \\
& P_{t}^{*}=P_{t-1}^{*}+\eta\left(P_{t-1}-P_{t-1}^{*}\right) \\
& Q_{t}=Q_{t-1}+\gamma\left(Q_{t}^{*}-Q_{t-1}\right)
\end{aligned}
$$

where $Q_{t}^{*}$ and $Q_{t}$ denote desired and actual level of output (acreage, production or yield) at time $\mathrm{t}, P_{t}^{*}$ and $P_{t}$ the expected and observed price, and $\mathrm{X}$ represents other exogenous factors affecting the supply at time $t$, such as price of competing crops, fixed and variable production costs, weather variables and technological changes. $\eta$ and $\gamma$ are the expectation and adjustment coefficients. The reduced form is 
obtained by solving the system (1)-(3) to eliminate the unobservable variables $Q_{t}^{*}$ and $P_{t}^{*}$ (Askary and Cummings, 1977):

$$
Q_{t}=b_{0}+b_{1} Q_{t-1}+b_{2} P_{t-1}+b_{3} X_{t}+\mu_{t}
$$

with $b_{2}$ measuring the short-run price elasticity of agricultural output. Equation (4) is the basic dynamic function considered in our analysis where $Q_{t}, Q_{t-1}, P_{t-1}$ and the set of exogenous factors are selected according to the choices described above. More specifically, we assume that farmers' decisions on acreage are based on the price expectations available at planting-time regarding the output price at harvest-time, marketing costs, competing crop prices, input prices, and other exogenous factors such as previous weather shocks. We also assume that once acreage has been allocated, farmers adjust their production decisions by increasing or decreasing the intensity of their farming activities during the growing season according to other factors such as current weather conditions (Oyejide, 1990). Following the existing literature, when we use production or yields as dependent variable in equation (4), we augment the set of variables in $X_{t}$ to include contemporary weather shocks, and drop competing crop prices and past weather shocks because they do not influence the farmers' choices between planting and harvesting (Haile et al., 2015).

For each output variable, we provide estimates of equation (4) alternating the farm-gate price and wholesale price for the same value chain as proxy for the past price, i.e. $P_{t-1}$. Following World Bank (1994), Mamingi (1996) and Thiele (2003), we decompose the price $P_{t}$ into its different components to trace separately the impact of direct incentives arising from border protection and government intervention in domestic markets, macroeconomic policies such as the exchange rate policy and variations in border prices. To do that, we rewrite the real producer price $P_{t}$ as:

$$
\begin{aligned}
P=\frac{P_{N}}{C P I}=\frac{P_{N}}{C P I} * \frac{P_{N}^{B}}{P_{N}^{B}} * \frac{e}{e} * \frac{W P I^{U S}}{W P I^{U S}} & = \\
& =\frac{P_{N}}{P^{B} * e} * \frac{W P I^{U S} * e}{C P I} * \frac{P_{N}^{B}}{W P I^{U S}}=N P C * R E R * P^{B}
\end{aligned}
$$

where $P_{N}$ is the nominal price at farm gate, $\mathrm{CPI}$ is the consumer price index used to calculate the real producer price $P, e$ is the nominal exchange rate (domestic units per US\$), WPI ${ }^{U S}$ is the US wholesale price index and $P_{N}^{*}$ the nominal price of the commodity at the border, expressed in US\$. As shown in the last term of Equation 5, the real producer price can be finally re-written as the product of three elements: i) the nominal protection coefficient (NPC); ii) the real exchange rate (RER); and iii) the border price expressed in real terms $\left(P^{B}\right)$. To embed them into the Nerlove model, we follow Chavas et al. (1983) and Parrott and McIntosh (1996) assuming that the expected price is a weighted average of these three elements. Therefore, we substitute equation (5) in (4) and we obtain:

$$
\begin{aligned}
& Q_{t}=b_{0}+b_{1} Q_{t-1}+b_{2} {\left[a_{1} N P C_{t-1}+a_{2} R E R_{t-1}+a_{3} P_{t-1}^{B}\right]+b_{3} X_{t}+\mu_{t} } \\
&=\beta_{0}+\beta_{1} Q_{t-1}+\beta_{2} N P C_{t-1}+\beta_{3} R E R_{t-1}+\beta_{4} P_{t-1}^{B}+\beta_{5} X_{t}+\mu_{t}
\end{aligned}
$$

where $\beta_{2}=b_{2} a_{1}, \beta_{3}=b_{2} a_{2}$ and $\beta_{4}=b_{2} a_{3}$. 
The NPC compares the farm-gate price with the maximum the farmers would get from selling their product on the world market. A ratio above (below) one indicates that producers of a specific commodity receive direct price incentives (disincentives) resulting from trade and domestic market policies and overall market performance. Clearly, we expect a positive supply responses to an increase in the NPC.

The RER measures the price ratio between tradeable and non-tradeable goods and it is influenced by macroeconomic policies, such as monetary and fiscal interventions (Mamingi, 1997). An increase in the RER - corresponding to a devaluation in real terms of the domestic currency - is expected to increase farmers' incentive to produce because it raises the price of tradeable relative to nontradeable goods. Finally, the border price captures the impact of price changes on the international market and we expect it to have a positive impact on the agricultural supply.

For estimating equation (4) and (6), we require a rich dataset with information on outputs, prices at different points of the value chain, marketing costs, a measure of policy support and other exogenous factors that influence farmers' decisions on staple food crops. Most of this information is provided by the MAFAP dataset (MAFAP, 2015) which covers more than 70 agricultural value chains spread over ten different SSA countries from 2005 to 2013. These countries are Burkina Faso, Ethiopia, Ghana, Kenya, Malawi, Mali, Mozambique, Nigeria, Tanzania and Uganda. For each value chain, farm-gate, wholesale and border output prices are collected together with the respective marketing costs, which include transport costs, processing costs, handling costs, taxes, fees and commercial margins of different agents. The ultimate data sources in most cases are government institutions such as statistical offices and research centres ${ }^{48}$.

In our analytical framework, the farm gate price is defined as the amount received by the producer for selling a unit of a good (i.e. tonne) as output minus any value added tax (VAT), or similar deductible tax paid by the purchaser. Similarly, the wholesale price is defined as the price observed in the market where the domestically produced commodity competes with the internationally traded commodity. It represents a point in the value chain between the farm gate and the point of entry (exit) of imported (exported) commodities (MAFAP, 2015). Finally, the border price represents the FOB (CIF) price for exported (imported) goods, with the underlying assumption that international prices can be considered as a valid benchmark for prices undistorted by domestic policies and free of influence of domestic market failures ${ }^{49}$.

\footnotetext{
${ }^{48}$ See Table 16 in the Appendix for detailed information on specific data sources.

${ }^{49}$ For more information on the methodology, see (MAFAP, 2015) at www.fao.org/in-action/mafap.
} 


\begin{tabular}{lll|lll}
\hline Country & Crop & Period & Country & Crop & Period \\
\hline Burkina Faso & Maize & $2005-2013$ & Kenya & Potatoes & $2005-2013$ \\
Burkina Faso & Sorghum & $2005-2013$ & Malawi & Maize & $2005-2013$ \\
Burkina Faso & Rice & $2005-2013$ & Mali & Maize & $2005-2012$ \\
Ethiopia & Maize & $2005-2012$ & Mali & Sorghum & $2005-2012$ \\
Ethiopia & Wheat & $2005-2012$ & Mali & Rice & $2005-2012$ \\
Ethiopia & Sorghum & $2005-2012$ & Mali & Millet & $2005-2012$ \\
Ethiopia & Barley & $2005-2012$ & Mozambique & Maize & $2005-2013$ \\
Ethiopia & Beans & $2005-2012$ & Mozambique & Rice & $2005-2013$ \\
Ghana & Maize & $2005-2013$ & Mozambique & Cassava & $2005-2013$ \\
Ghana & Rice & $2005-2013$ & Nigeria & Sorghum & $2005-2010$ \\
Ghana & Cassava & $2005-2011$ & Nigeria & Rice & $2007-2010$ \\
Ghana & Yam & $2005-2012$ & Uganda & Maize & 2005-2013 \\
Kenya & Maize & $2005-2013$ & Uganda & Wheat & 2005-2013 \\
Kenya & Wheat & $2005-2013$ & Uganda & Rice & $2005-2013$ \\
Kenya & Sorghum & $2005-2013$ & Uganda & Cassava & $2005-2013$ \\
Kenya & Rice & $2005-2013$ & Tanzania & Maize & $2005-2013$ \\
Kenya & Cassava & $2005-2012$ & Tanzania & Rice & 2005-2013 \\
Kenya & Beans & $2005-2012$ & & & \\
\hline
\end{tabular}

Source: FAO-MAFAP Database

In our analysis, we use a subset of the MAFAP database that only includes staple food crops. We consider ten commodities belonging to three main commodity groups considered essential for food security in SSA: cereals (maize, wheat, sorghum, rice, millet, barley); roots and tubers (cassava, yams, potatoes); and pulses (beans). Since not all the staple food crops are produced in the ten countries represented in our dataset, our panel data is unbalanced. Consequently, we decided to work with country-commodity pairs in the empirical analysis (see sections 4 and 5). Table 12 provides a full list of the 35 value chains used for our empirical exercise together with the period covered by the dataset. The most represented country is Kenya - with seven value chains - while Malawi has only one value chain. Maize is present in all countries except in Nigeria. Although in some countries the number of commodities may appear limited, Figure 17 shows that their relevance for food security is substantial. The commodities in our dataset cover over $45 \%$ of the total food supply (kcal/capita/day) in the 10 countries we consider, and over $50 \%$ in six of these countries. 


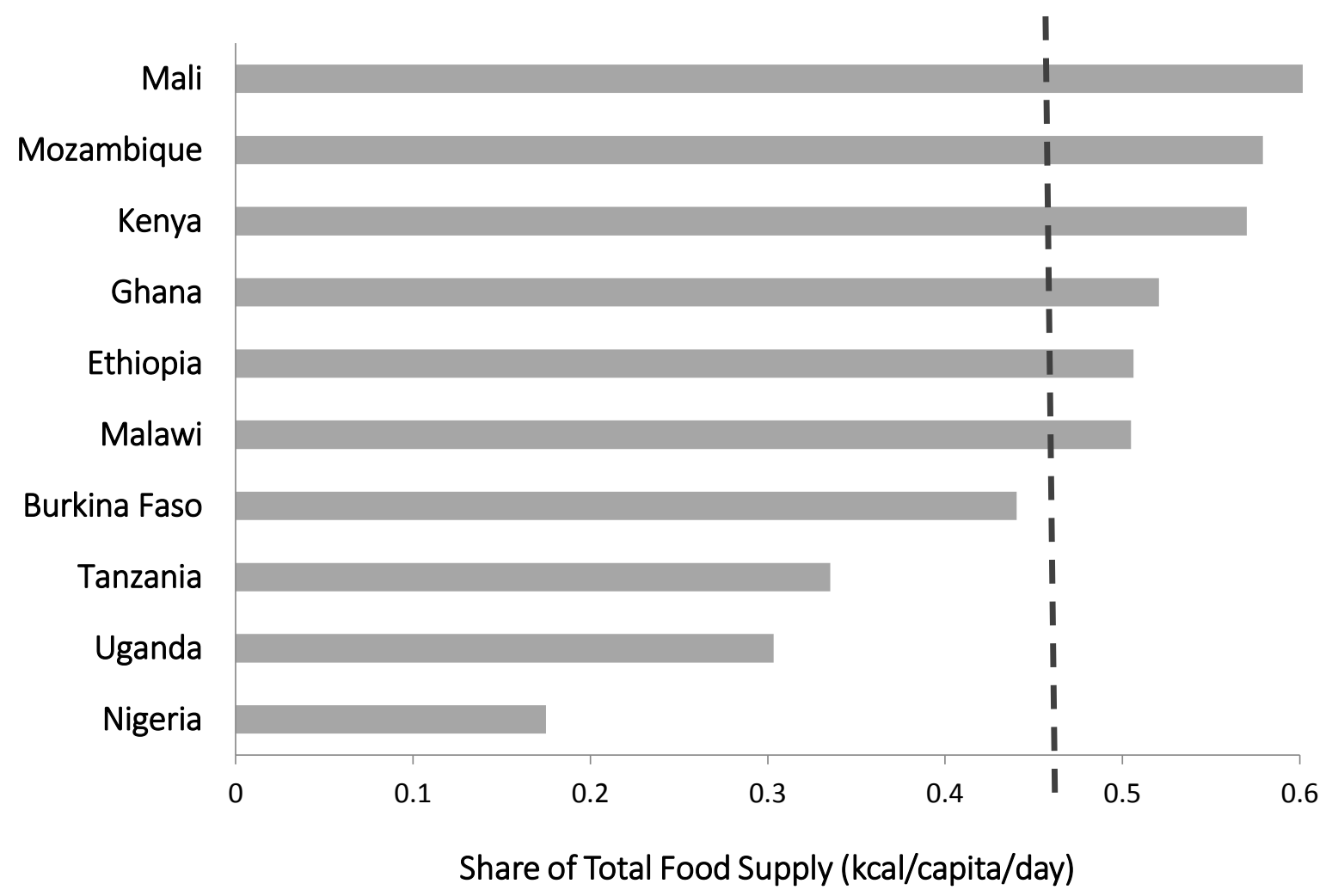

Note: Authors' calculations from FAOSTAT (FAO, 2015).

We deflate farm-gate and wholesale prices and marketing costs using the consumer price index (CPI) provided by World Bank (WDI, 2015), assuming that farmers react to the relative prices of the produced crop with respect to the prices of the others goods in the market. Accounting for price of other good is coherent with our assumption that farmers want to improve their food security status buying other goods than those they produce. Additionally, it allows us to obtain price proxies expressed in real terms. Ideally, we would deflate prices using a CPI that excludes the commodity in question to obtain the true relative price of that commodity. However, such data are not available. Finally, we take from the World Bank (WDI, 2015) the US wholesale price index and the official nominal exchange rate necessary to calculate the nominal protection coefficient, the real exchange rate and the real border price.

Besides the data on prices, we also need data on agricultural output, competing output prices, input prices and weather conditions. For the dependent variables - commodity-specific acreage, production and yield for each country - we use data provided by FAOSTAT (FAO, 2015). Recall that FAO data on acreage refer to harvested area and not to the actual variable of interest, which is planted area. Using the harvested area could bias the results because it may differ from planted area as result of factors outside the farmers' control. In order to capture the effect of competing commodity prices on acreage decision, we use the producer price index of the respective food group, i.e. cereals, roots and tubers, and pulses provided by FAOSTAT (FAO, 2015). Ideally, we would use the price of the actual competing commodity, but the unbalanced nature of our panel prevents us from adopting this solution. As for the proxy of the relative cost of inputs, we use the ratio of the annual West Texas Intermediate (WTI) oil price index (Energy Information Agency of the United States, 2015) to the producer price index for 
the aggregate agricultural sector (FAO, 2015). This ratio can also be interpreted as a measure of profitability (Askari and Cummings, 1977).

Finally, to capture the influence of weather conditions on agricultural supply, we use different weather variable depending on the proxy selected to estimate supply in the response function. For planted acreage, farmers are likely to take into consideration what happened in the past to formulate their decision. Some studies employ past yield shocks (with respect to a long-run trend) as a proxy for weather and other natural shocks effects (e.g. Roberts and Schlenker, 2009; Roberts and Schlenker, 2013; Haile et al., 2015). The main limitation of this approach is that the deviations from the trend are completely attributed to weather-related events while there might be other exogenous factors influencing them (Roberts and Schlenker, 2009). Nevertheless, the same proxy cannot be used to explain production and yield responses because a) after planting, it cannot be argued that the past natural shocks influence the intensity of farming; b) using the yield shocks in the production or yield function raises endogeneity problems due to likely collinearity with other variables, especially the lagged dependent variable. Accordingly, some authors control for contemporaneous weather and other natural shocks to explain production and yield response by employing direct information on weather variables such as precipitation, moisture and temperature (Askari and Cummings, 1977). This is often hampered by the lack of primary data sources in developing countries - especially in SubSaharan Africa -due to the limited coverage of weather stations in agricultural areas (Rojas et al., 2011). We address this constraint using an FAO indicator based on remote sensing data, i.e. the Agricultural Stress Index (ASI). The ASI captures the anomalous vegetation growth and potential drought in arable land during the cropping season. Specifically, the ASI measures the temporal intensity and duration of dry periods and estimates the percentage of arable land affected by drought $(F A O, 2015)^{50}$. The information collected using satellite technology to generate the ASI is synthesized at the country level and can therefore be employed in the supply function to estimate the effect of weather-related conditions occurred between planting and harvesting. Descriptive statistics of the variables used in the empirical analysis are given in Table 17 of the Appendices.

\subsection{Empirical model}

The supply response functions estimated in this study are based on equation (4) and (6) presented in section 2 and take the following forms:

$$
\begin{gathered}
Q_{i, t}=b_{0}+b_{1} Q_{i, t-1}+b_{2} P_{i, t-1}+b_{3} X_{i, t}+\rho t_{i}+\eta_{i}+\mu_{i, t} \\
Q_{i, t}=\beta_{0}+\beta_{1} Q_{t-1}+\beta_{2} N C P_{i, t-1}+\beta_{3} R E R_{t-1}+\beta_{4} P_{i, t-1}^{B}+\beta_{5} X_{i, t}+\rho t_{i}+\eta_{i}+\mu_{i, t}
\end{gathered}
$$

where $Q_{i, t}$ indicates the level of acreage, production or yield for the country-commodity pair i-for example maize in Kenya - at time $t, P_{i, t-1}$ the farm-gate or wholesale price of the same pair $\mathrm{i}$ at time $\mathrm{t}$ $1, X_{i, t}$ the vector of control variables, while $t_{i}$ and $\eta_{i}$ are - respectively - a time trend capturing technological and structural changes and a country-commodity fixed effect to capture heterogeneity across different value chains. For equation (8), NCP, RER and $P^{B}$ indicate, respectively, the nominal

\footnotetext{
${ }^{50}$ For more information on the ASI, refer to http://www.fao.org/climatechange/asis/en/
} 
coefficient of protection, the real exchange rate and the border prices in real terms while $\mu_{i, t}$ is a normally distributed error term with mean zero and variance $\sigma^{2}$.

Due to a relatively limited number of observations for each country-commodity pair, we pool the data and test for specific country/commodity-specific heterogeneity (see Table 12). This specification allows us to exploit all the panel dimensions of the dataset and obtain short-run cross-country price elasticities for staple food crops in SSA relying on robust inference (Onal, 2012). The vector of control variables, $X_{i, t}$, contains different elements depending on the supply proxy used for estimating equation (7) and (8), as discussed above. For acreage, we include marketing costs, the producer price index of the respective food group, the real oil price, yield shocks, a dummy for the food price crises, and a time trend. For production and yield, we drop the proxy for the competing price and the yield shocks and add the ASI. All the continuous variables used for estimating the model - except for the Producer Price Index and the ASI - are in logarithmic form so that coefficients can be interpreted in terms of percentage changes, which is particularly convenient for analyzing the short-run price elasticity.

There are a number of reasons why endogeneity might affect our estimates. Estimating equation (7) and (8) using Ordinary Least Squares (OLS) or Fixed Effects(FE) would yield biased estimates because of the correlation between the lagged dependent variable and the country fixed effect - the so-called dynamic panel bias (Nickell, 1981). As extensively discussed in the literature - even after the withingroup transformation - the lagged dependent variable $Q_{i, t-1}$ would still be correlated with the error term, providing biased and inconsistent estimates for the fixed effect estimator. The problem becomes smaller as the length of the panel (T) grows (Nickell, 1981 and Roodman, 2009a). However, our data only include 9 years. The most common solution to the dynamic panel bias problem is the Generalized Method of Moments (GMM) estimator developed by Arellano and Bond (1991).One option is to use the difference-GMM estimator which consists of first differencing the data to eliminate the fixed-effect and, then, of instrumenting the first-differenced equation with the lagged level of the series. A more suitable alternative in our setting is to estimate the system-GMM as proposed by Blundell and Bond (1998). They refine the difference-GMM by transforming the instruments themselves in order to make them exogenous to the fixed effects (Roadman, 2009). In other words, they propose to estimate a system of equations in both differences and levels, where the instruments for the levels equation are the lagged first-differences of the series (Bond et al., 2001). Blundell and Bond (1998) show that when $\mathrm{T}$ is small there are significant gains in applying the system-GMM rather than the difference-GMM, provided that the initial conditions are not correlated with the fixed effect. Moreover, the differenceGMM performs quite poorly when series are persistent or close to being random walks, while the system-GMM estimator is consistent in the presence of unit roots (Bond, 2002; Binder et al., 2005).

In order to validate the system-GMM estimates, sensitivity analyses and robustness checks on the instrument choice and serial correlation are required. To avoid the instrument proliferation problem, we follow Roodman (2009b) by "collapsing" the instrument matrix and checking if we can exclude longer lags instead of using all the available information. Since the GMM estimator can be influenced by this choice, we test its stability by showing how the coefficients vary with the number of chosen lags $^{51}$. Once the number of instruments has been fixed, we test both the validity of the full set of instruments using the Hansen test and the validity of a subset of instruments - precisely those for the levels equation based on lagged differences of the dependent variable-calculating the difference-inHansen statistics. The latter test is necessary because the original Hansen test may be weakened in case of instrument proliferation. Moreover, it allows us to confirm the Blundell and Bond (1998)

\footnotetext{
${ }^{51}$ While Hendricks (2012) highlighted this problem, the literature does not provide more robust guidance on how one should choose the optimal number of lags in a dynamic panel data setting.
} 
assumption on the initial conditions (Roodman, 2009b). The other statistic reported is the ArellanoBond test for autocorrelation which looks at the second-order correlation in difference to test for the first order serial correlation in levels of the error term. As additional robustness check, we compare the system-GMM estimates with estimates obtained with OLS, FE and difference-GMM. The main purpose is to verify that the coefficient of the lagged dependent variable lies in the credible range defined by Roodman (2009a), which is between the FE coefficient (lower bound) and the OLS coefficient (upper bound). Finally, we use the Windmeijer (2005) correction to obtain robust standard errors since two-step GMM estimates are biased downward in finite samples.

\subsection{Results}

Before estimating the supply function, we control for the stationarity of the variables in our dataset. We use two panel unit root tests suitable for unbalanced panel dataset, the Im-Pesaran-Shin test and the Fisher-type test. In both cases, the null hypothesis is that all the panels contain a unit root. Table 18 in the Appendix shows that only acreage, production, producer price index and real oil price are not stationary in levels while all of them are stationary once differenced. As far as the first-difference variables are stationary, the presence of some non-stationary variables in levels is not an issue considering that it will be addressed by the GMM during the differencing process, giving consistency to the estimates (Yu et al., 2012).

Table 13,Table 14,Table 15 show the results of the empirical estimation of equation 7 and 8 using acreage, production and yield as dependent variables, respectively. For each table, column (1) and (2) report the supply response using - respectively - the lagged farm-gate and the wholesale price to proxy the expected price. We note that the short-run price elasticity of supply is always positive and statistically significant, no matter which dependent variable or price we use in the response function. More specifically, if the own-price of any given staple food crops at farm-gate level increases by $10 \%$, acreage rises by $2.2 \%$, production by $6 \%$ and yield by $3.0 \%$. At the same time, if we consider the wholesale price as proxy of the farmers' expected price, the results show that a $10 \%$ rise in price will cause an increase of $3.9 \%$ in acreage, $6.2 \%$ in production and $4.0 \%$ in yield. Looking at this initial set of results, we can make several observations. First of all, farmers in SSA are able to interpret the market signals and respond positively to an increase of the real price of staple food crops, as suggested by economic theory. Furthermore, the results show that farmers use price information not only to decide how much acreage to plant, but also to modify their farming intensity during the cropping season.

Nevertheless - although the estimated price elasticities are positive and statistically significant in all the cases - they are quite small and range from 0.216 to 0.596 . Production and yield responses are higher than those for acreage, confirming that acreage should be considered as a lower bound for the total price elasticity of supply (Rao, 1989). 
(1)

$0.976 * * *$

[0.051]

$0.216 * * *$

[0.066]

WS Price $(t-1)$

Nominal Coefficient of Protection (t-1)

Real Exchange Rate (t-1)

Border Price (t-1)

Marketing Cost (t-1)

Producer Price Index (t-1)

Yield Shock (t-1)

Real Oil Price (t-1)

Food Crises

Time Trend
(2)

(3)

0.970***

$0.989 * * *$

[0.060]

[0.074]
$0.394 * * *$

[0.103]

$0.312 * *$

[0.156]

0.020

[0.220]

$0.289 * *$

[0.147]

$-0.119$

[0.161]

$-0.185^{*}$

[0.106]

$0.033^{* * *}$

[0.011]

$-0.189$

[0.178]

0.062

[0.042]

0.013

[0.020]

$\begin{array}{lccc}\text { Observations } & 273 & 273 & 273 \\ \text { Number of Instruments } & 22 & 22 & 24 \\ \text { F-Test for Joint Significance } & 0.000 & 0.000 & 0.000 \\ \text { Hansen Test (p-value) } & 0.621 & 0.409 & 0.376 \\ \text { Diff-in-Hansen Test (p-value) } & 0.443 & 0.408 & 0.298 \\ \text { AR (1) Test } & 0.000 & 0.000 & 0.000 \\ \text { AR (2) Test } & 0.153 & 0.134 & 0.143\end{array}$

Note: coefficients are two-step system-GMM estimates with the lagged dependent variable and the price variable treated as predetermined. In parentheses, robust standard errors with the Windmeijer (2005) correction finite sample are reported. All the instrument matrices are "collapsed". The Diff-in-Hansen test reports the p-values for the validity of the additional moment restriction necessary for system GMM. The $A R(1)$ and $A R(2)$ report the $p$-values for first and second order autocorrelation of the first-differenced residuals. Stars $*, * *$, and $* * *$ represent the $10 \%, 5 \%$, and $1 \%$ levels of significance, respectively. 
(1)

Production (t-1)
(2)

$0.865^{* * *}$

[0.106]

WS Price (t-1) $0.621^{* * *}$

[0.166]

Nominal Coefficient of Protection ( $t-1$ )

Real Exchange Rate (t-1)

$0.559 * *$

[0.258]

$0.399 * *$

[0.156]

Border Price (t-1)

$0.688^{* * *}$

[0.151]

Marketing Costs (t-1)

$-0.351 * *$

$-0.429 *$

$-0.315^{* *}$

[0.154]

[0.219]

Agricultural Stress Index

$-0.565 *$

$-0.481$

[0.156]

[0.320]

[0.414]

$-0.527^{* *}$

[0.245]

Real Oil Price (t-1)

$-0.501^{*}$

$-0.334$

$-0.369$

[0.285]

[0.308]

[0.307]

Food Crises

0.036

0.042

$0.075^{*}$

[0.036]

[0.038]

[0.045]

Time Trend

$-0.040 * * *$

$-0.035^{* *}$

[0.015]

[0.015]

$-0.045^{* * *}$

[0.011]

\section{Observations \\ F-Test for Joint Significance \\ Hansen Test (p-value) \\ Diff-in-Hansen Test (p-value) \\ AR (1) Test \\ AR (2) Test}

273

273

273

19

19

22

0.000

0.000

0.000

0.487

0.297

0.927

0.937

0.451

0.577

0.000

0.000

0.000

0.139

0.331

0.156

Note: coefficients are two-step system-GMM estimates with the lagged dependent variable and the price variable treated as predetermined. In parentheses, robust standard errors with the Windmeijer (2005) correction finite sample are reported. All the instrument matrices are "collapsed". The Diff-in-Hansen test reports the p-values for the validity of the additional moment restriction necessary for system GMM. The $A R(1)$ and $A R(2)$ report the $p$-values for first and second order autocorrelation of the first-differenced residuals. Stars $*, * *$, and $* * *$ represent the $10 \%, 5 \%$, and $1 \%$ levels of significance, respectively. 


\begin{tabular}{|c|c|c|c|}
\hline & (1) & $(2)$ & (3) \\
\hline \multirow[t]{2}{*}{ Yield $(t-1)$} & $0.998 * * *$ & $0.961^{* * *}$ & $0.970 * * *$ \\
\hline & {$[0.063]$} & {$[0.062]$} & [0.065] \\
\hline \multirow[t]{2}{*}{ FG Price $(t-1)$} & $0.297 * * *$ & & \\
\hline & {$[0.097]$} & & \\
\hline \multirow[t]{2}{*}{ WS Price (t-1) } & & $0.406 * *$ & \\
\hline & & {$[0.180]$} & \\
\hline \multirow[t]{2}{*}{ Nominal Coefficient of Protection ( $t-1$ ) } & & & $0.212^{*}$ \\
\hline & & & {$[0.122]$} \\
\hline \multirow[t]{2}{*}{ Real Exchange Rate (t-1) } & & & 0.231 \\
\hline & & & [0.199] \\
\hline \multirow[t]{2}{*}{ Border Price (t-1) } & & & $0.384 * * *$ \\
\hline & & & {$[0.123]$} \\
\hline \multirow[t]{2}{*}{ Marketing Costs (t-1) } & $-0.273 * * *$ & $-0.367^{*}$ & -0.264 \\
\hline & {$[0.094]$} & [0.187] & [0.187] \\
\hline \multirow[t]{2}{*}{ Agricultural Stress Index } & $-0.446 * *$ & $-0.427^{*}$ & $-0.401^{*}$ \\
\hline & {$[0.203]$} & {$[0.230]$} & {$[0.230]$} \\
\hline \multirow[t]{2}{*}{ Real Oil Price (t-1) } & -0.207 & -0.149 & -0.211 \\
\hline & {$[0.271]$} & {$[0.258]$} & {$[0.297]$} \\
\hline \multirow[t]{2}{*}{ Food Crises } & $-0.072 *$ & -0.040 & -0.038 \\
\hline & {$[0.038]$} & {$[0.040]$} & {$[0.038]$} \\
\hline \multirow[t]{2}{*}{ Time Trend } & $-0.027 * *$ & $-0.020 *$ & $-0.030 * * *$ \\
\hline & {$[0.011]$} & {$[0.012]$} & {$[0.011]$} \\
\hline Observations & 273 & 273 & 273 \\
\hline Number of Instruments & 19 & 19 & 22 \\
\hline F-Test for Joint Significance & 0.000 & 0.000 & 0.000 \\
\hline Hansen Test ( $p$-value) & 0.584 & 0.333 & 0.891 \\
\hline Diff-in-Hansen Test (p-value) & 0.436 & 0.648 & 0.704 \\
\hline AR (1) Test & 0.000 & 0.000 & 0.000 \\
\hline AR (2) Test & 0.357 & 0.435 & 0.608 \\
\hline
\end{tabular}

Note: coefficients are two-step system-GMM estimates with the lagged dependent variable and the price variable treated as predetermined. In parentheses, robust standard errors with the Windmeijer (2005) correction finite sample are reported. All the instrument matrices are "collapsed". The Diff-in-Hansen test reports the p-values for the validity of the additional moment restriction necessary for system GMM. The $A R(1)$ and $A R(2)$ report the $p$-values for first and second order autocorrelation of the first-differenced residuals. Stars $*, * *$, and $* * *$ represent the $10 \%, 5 \%$, and $1 \%$ levels of significance, respectively. 
From tables 13, 14 and 15 we also see that the elasticity of supply with respect to the wholesale price (reported in column 2) is always higher than the elasticity with respect to the farm-gate price (reported in column 1). On average, this upward bias seems to be around 0.1 , with a range that goes from 0.03 for production to 0.18 for acreage. The result can be explained referring to the work of Gardner (1975) on vertical price transmission. He shows that the elasticity of price transmission of the retail price with respect to the producer price is less than unity while other authors apply the same logic to the price spread between wholesale and farm gate price (e.g. Brummer et al., 2009). If this relationship is true, the price elasticity with respect to the farm gate price $\left(b_{2}^{f g}\right)$ is equal to the price elasticity with respect to the wholesale price $\left(b_{2}^{w s}\right)$ multiplied by the elasticity of price transmission between farm gate and wholesale prices $\left(e_{f g}^{w s}\right)$, i.e. $b_{2}^{f g}=b_{2}^{w s} * e_{f g}^{w s}$. As a consequence, $b_{2}^{f g}$ will always be lower than $b_{2}^{w s}$ as reported in tables 13,14 and 15 . Therefore, using wholesale prices to analyze supply responses instead of farm-gate prices might overestimate the supply response because it implies assuming perfect price transmission between different segments of the value chain. However, the literature extensively showed that this is often not the case in developing countries, mainly because of market failures imperfect competition, high transaction costs, information asymmetries - and policy interventions (Key et al., 2000; Rapsomanikis et al., 2006; Short et al., 2014; and Balié and Morales Opazo, 2016).

Figure 18: Price elasticity with and without marketing costs

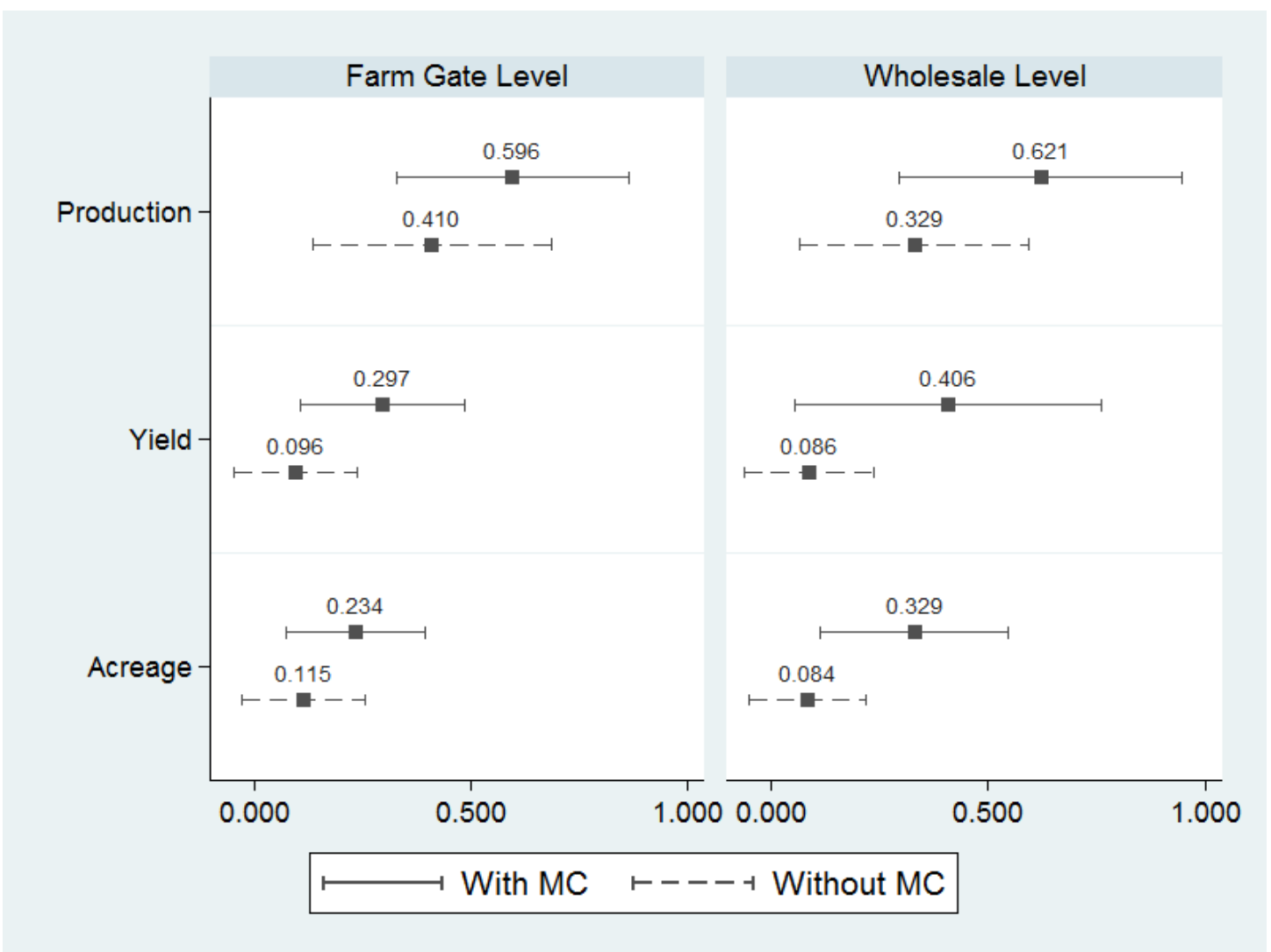

Note: price elasticity (FG \& WS Price) represented in the figure are obtained using the two-step system-GMM estimates described in table 13, 14 and 15. Solid line reports the coefficient including the Marketing Cost in the regression (With MC) while dotted line reports the same regression excluding the marketing cost as covariate from the model (Without MC). The amplitude of the lines indicates the $90 \%$ confidence interval of the coefficient.

Besides the output price of the crop they produce, farmers also react to other factors such as the marketing costs (transport, processing, handling, taxes, fees and margins) paid to other agents along the value chain. As already mentioned, thanks to the flexibility and richness of the MAFAP dataset, we 
are able to control for specific country/crop marketing costs in our regression and the results we obtain are quite clear. As shown in tables 13,14 and 15, the higher the marketing costs the lower the supply response, confirming that excessive marketing costs might prevent farmers to fully exploit market signals. The reported coefficients for the marketing costs are so close to those reported for the price elasticities that positive price shock, even substantial, might be easily offset by a similar increase in, for example, transport costs or local transit taxes. To further clarify the importance of introducing marketing costs in the supply response function, Figure 18 reports how the price elasticity of supply would change estimating equation 5 with or without them. As expected, not considering the marketing costs would bring the price elasticity estimates downward. This is explained mainly by the positive correlation between marketing costs and the farm-gate and wholesale prices. The bias can turn out to be quite substantial and more than 0.3 . In this respect, our exercise suggests that the observed low elasticities obtained by previous empirical estimates may not be entirely due to the lack of response from farmers but also to the difficulty to control for such marketing costs. In other words, previous studies may not have fully captured that - beyond the price signals - market imperfections are of critical importance in driving the supply response. This appears to be a useful finding for policy makers as it stresses the importance of addressing market functioning notably through targeted public investments to, for instance, lower transport costs or improve governance to eliminate illicit taxes along the value chain.

In table 13, the PPI of the food group containing the competing crops turns out to be negative - as expected - but not statistically significant. The non-significance of the coefficient can have one economic and one methodological explanation. Economically, it might indicate that once we control for more important factors such as the own-price and the marketing costs, the price of the competing crops is not a crucial factor in determining the farmers' decision on acreage. Indeed, the lack of significance of this factor has already been observed by other empirical works (Onal, 2012 and Haile et al., 2015). From a methodological standpoint, we cannot control for specific competing crops because our panel is unbalanced and prices are not available. As a consequence, the PPI of the competing group (e.g. cereals for maize or roots and tubers for cassava) may not fully capture those cross-price effects (e.g. wheat or rice price on maize). The real oil price in our results displays the expected negative sign but it is never statistically significant, except in column (1) of table 14. This negative sign confirms that the higher the cost of inputs, the lower the level of agricultural output. The lack of statistical significance can be explained by the fact that the input usage in SSA is quite limited, especially for the case of the staple food crops analyzed in this paper. Moreover, the oil price might be only weakly correlated with the price of the relevant basket of inputs, which also varies from country to country and crop to crop.

The weather proxies - yield shocks for acreage in table 13 and the Agricultural Stress Index for production and yield in table 14 and 15 - always show the expected sign ${ }^{52}$. In our experiment, the yield shocks turn out to be positive and statistically significant indicating that past positive deviations from the long-term trend are an incentive to expand the planted acreage. At the same time, the ASI is always negative, confirming that long and intense dry periods during the growing season reduce production and - consequently - yields. Lastly, we augment our supply functions introducing a dummy controlling for the recent food price crises (2008 and 2011) and a time trend to capture any other shocks due to institutional or unobservable factors. Interestingly, during the price crises, acreage has been - on

\footnotetext{
${ }^{52}$ Yield shocks are calculated as the jack-knifed residuals obtained from separate regressions of yield on time trend for each country-crop pair. We do not employ OLS residuals because they would give biased estimates of the errors (Roberts and Schlenker, 2009).
} 
average $-10 \%$ higher than the usual level while production increased but only by $3-4 \%$ resulting in a reduction in yields.

Finally, in column 3 of table 13, 14 and 15, we replace the observed price with the nominal protection coefficient, the real exchange rate and the border price expressed in real terms. As explained above, the purpose is to disentangle the effect of the observed price into three components: the direct incentives arising from border measures and interventions in domestic markets, the macroeconomic policy and the price variations in the international market. Results show that the three variables have a positive impact on the supply response, respecting the expected sign. Direct incentives and changes in the border price significantly stimulate the farmers' response in all cases while the real exchange rate is statistically significant only in table 14. It means that macroeconomic decisions, especially on the exchange rate influence production decisions while they are not affecting acreage allocation and, consequently, yields.

In order to validate the results obtained with the system-GMM estimator, we report some sensitivity analyses and robustness checks. The first test regards the sensitivity of our estimates to alternative number of lags used as instrumental variables. Figure 19,Figure 20 and Figure 21 in the Appendix show how the coefficient of the lagged dependent variable and the price elasticity for - respectively acreage, production and yield change according to the maximum lag selection. As expected, a limited number of instruments return less efficient point estimates with higher confidence intervals (Roodman, 2009b). Considering the importance of the point estimates for the present work, especially for price elasticity, we prefer to use all the available lags (i.e. eight) as instruments to ensure higher stability to our coefficients. The downside of this choice is that we risk overfitting the lagged dependent variable, pushing its coefficient towards the one obtained with OLS. Nevertheless, the reported figures show that reducing the number of lags changes neither the autoregressive coefficient nor the price elasticity substantially.

The Hansen J-statistics for over-identifying restrictions reported in tables 13, 14 and 15 also confirm the goodness of the instrument set. In all cases, the $p$-value is higher than $10 \%$, indicating that the null hypothesis of joint validity cannot be rejected. Following Roodman (2009b), we also use the differencein-Hansen test to check if the lagged differences of the dependent variable are good instruments for the levels equation in order to verify the Blundell-Bond hypothesis on the system-GMM initial conditions. The exogeneity of this subset of instruments is confirmed in all cases, with $p$-values at least greater than $15 \%$. The $\mathrm{AR}(1)$ and $\mathrm{AR}(2)$ tests in tables 13, 14 and 15 report the Arellano-Bond test for first and second-order autocorrelation of the differenced residuals. In all cases, the test for $A R(1)$ rejects the null hypothesis of no serial correlation while the test for $A R(2)$ fails to reject it, showing no evidence of autocorrelation at conventional levels of significance in our estimates.

Lastly, we check the robustness of our results by verifying that the estimated coefficients of the lagged dependent variable range between the fixed-effects estimate - which should be biased downward and the OLS estimate - which should represent an upper bound (Roodman, 2009a). Figure 22, 23 and 24 in the Appendix compare the autoregressive coefficient and the price elasticity for - respectively acreage, production and yield obtained using OLS, Fixed Effects, difference-GMM and system-GMM. In all the cases, the system-GMM coefficient on the lagged dependent variable lies between the FE and OLS estimates. As already noted by Haile et al. (2015), the autoregressive coefficient for the difference GMM behaves quite differently from the system-GMM, with an estimate closer to the FE and - in some cases - even below the credible bound. This and the fact that the system-GMM better handles the high persistence of the output supply both support our choice of the system-GMM estimator. Finally, Figure 22, Figure 23 and Figure 24 show that the model selection substantially influences the estimates and it suggests that both OLS and FE results are always close to zero while 
GMM results give higher elasticities. Earlier estimates that were largely based on OLS and FE might have therefore contributed to the consensus that farmers in SSA do not react to price incentives.

\subsection{Conclusion}

Better understanding if and how farmers react to price signals is one of the key priorities for policy makers interested in designing effective strategy to reduce or eliminate food insecurity in Sub-Saharan Africa. We shed more light on this topic by providing a cross-country analysis of the supply response for the major staple food crops in ten SSA countries over the period 2005-2013. To do that, we rely on a recent dataset produced by the Food and Agriculture Organization (FAO) in the framework of its "Monitoring and Analyzing Food and Agricultural Policies" (MAFAP) programme.

The results of this empirical exercise show that farmers in SSA are actually capable of interpreting market signals and responding to changes in staple crop prices. However, the magnitude of the response is small and, often, partially or totally muted by other factors. We also find that the supply responses are significantly influenced by transaction costs paid by farmers to market their product. In this respect, we also suggest that results of the previous empirical works observing lower or even absent supply response to price shocks were not driven only by the impact of price signals but also by the impossibility to control for offsetting elements such as high marketing costs. Not surprisingly, we also find that past and current weather shocks play an important role in explaining the farmers' decisions and supply performances while the cross-prices of the competing commodities and the cost of inputs seem to be less important. By decomposing the expected price into three components - the nominal coefficient of protection, the real exchange rate and the border price - we find that farmers in SSA respond to price signals arising primarily from direct incentives generated by border measures and government interventions in domestic markets and shocks in the international market. On the contrary, they are less stimulated by macroeconomic policies affecting the exchange rate.

We consider the findings of this cross-country analysis useful for policy makers seeking evidence to support and improve food security in the SSA region through a better management of their own agricultural resources. Producers of staple food crops can exploit market opportunities but their response to price signals is still too low. Governments should move public resources away from current discretionary interventions and redirect them towards more effective investments such as transport and other physical infrastructures, market information systems, research and technology, extension services but also transparent market regulations. An increase in the the provision of these public goods is likely to support a more effective price transmission along the value chains and stimulate a more active smallholder market participation capable of properly reacting to price signals.

Moreover, while national-level efforts are necessary, they are not sufficient to guarantee food availability and access in the region. Although it is well known that Sub-Saharan Africa has the potential to massively increase its agricultural production and drastically reduce food insecurity, farmers have not exploited much of the growth opportunities of the last decade such as the recent high prices for staple food crops (Saghir, 2014). As indicated by the World Bank (2012), this failure can be partially explained by the lack of coordination between governments to remove the unnecessary barriers to the creation of a fully integrated African market to boost regional staple food trade and most likely help increase the currently low supply response for staple food crops to price signals. Should the governments decide to tackle these major policy failures, they would not only make faster progress to reduce food insecurity but also create the condition for those regional complementarities to materialize and boost overall growth. 
Anderson, K. and Masters, W. (Eds.) 2009. Distortions to Agricultural Incentives in Africa. Washington, DC, World Bank.

Arellano, M., \& Bond, S. (1991). Some tests of specification for panel data: Monte Carlo evidence and an application to employment equations. The Review of Economic Studies, 58(2), 277-297.

Askari, H., \& Cummings, J. T.. (1977). Estimating Agricultural Supply Response with the Nerlove Model: A Survey. International Economic Review, 18(2), 257-292.

Balié, J and Morales Opazo, C. (2016). Is policy support boosting maize production in Africa? Food Security forthcoming.

Baffes, J and Gardner, B. (2003). The transmission of world commodity prices to domestic markets under policy reforms in developing countries. Journal of Economic Policy Reform, Taylor \& Francis Journals, vol. 6(3), pages 159-180.

Barr, K. J., Babcock, B. A., Carriquiry, M. A., Nassar, A. M., \& Harfuch, L. (2011). Agricultural Land Elasticities in the United States and Brazil. Applied Economic Perspectives and Policy, 33(3), 449462.

Barrett, C.B. (2008.) Smallholder Market Participation: Concepts and Evidence from Eastern and Southern Africa. Food Policy 33:299-317.

Bates, R. (1983). Essays on the Political Economy of Rural Africa. African Studies Series No. 38.

Binder, M., Hsiao, C., \& Pesaran, M. H. (2005). Estimation and inference in short panel vector autoregressions with unit roots and cointegration. Econometric Theory, 21(04), 795-837.

Binswanger, H., Yang, M. C., Bowers, A., \& Mundlak, Y. (1987). On the determinants of cross-country aggregate agricultural supply. Journal of Econometrics, 36(1), 111-131.

Bloom, D and Sachs, J. (1998). Geography, Demography, and Economic Growth in Africa. Brookings Papers on Economic Activity, 2, pp. 207-295. Cambridge: Cambridge University Press, 1983, 178 pp.

Blundell, R., and S. Bond. (1998). Initial conditions and moment restrictions in dynamic panel data models. Journal of Econometrics 87: 11-143.

Bond, M. (1983). Agricultural Responses to Prices in Sub-Saharan Africa. International Monetary Fund Staff Papers, 30(4), 703-726.

Bond, S. 2002. Dynamic panel data models: A guide to micro data methods and practice. Working Paper 09/02. Institute for Fiscal Studies. London

Braulke, M., 1982, A note on the Nerlove model of agricultural response. International Economic Review 23, 241-244.

Brümmer, B., von Cramon-Taubadel, S., \& Zorya, S. (2009). The impact of market and policy instability on price transmission between wheat and flour in Ukraine. European Review of Agricultural Economics, 36(2), 203-230.

Chavas, J. P., Pope, R. D., \& Kao, R. S. (1983). An analysis of the role of futures prices, cash prices and government programs in acreage response. Western Journal of Agricultural Economics, 27-33.

Chavas, J. P. (2000). On information and market dynamics: the case of the US beef market. Journal of Economic Dynamics and Control, 24(5), 833-853.

Clover, J. (2003). Food security in sub-Saharan Africa. African Security Studies, 12(1), 5-15.

Coyle, B.T. (1993). On Modelling Systems of Crop Acreage Demands. Journal of Agricultural and Resource Economics 18 (1): 57-69.

Coyle, B. T. (1999). Risk aversion and yield uncertainty in duality models of production: a meanvariance approach. American Journal of Agricultural Economics, 81(3), 553-567.

Dawe, D., Morales-Opazo, C., Balie, J., Pierre, G. (2015). How much have domestic food prices increased in the new era of higher food prices? Global Food Security, Vol. 5: 1-10. 
Di Marcantonio, F; MoralesOpazo, C and Barreiro-Hurle. J. (2014). Determinants of food production in Sub Saharan Africa: The impact of policy, market access and governance. Paper for the 2014 EAAE Congress in Ljubljana, Slovenia, 26-29 August.

Ezekiel, M. (1983). The Cobweb Theorem. Journal of Economics. 52. 225.239

FAO (Food and Agriculture Organization). (2015). MAFAP database. (available at: http://www.fao.org/mafap/database/en/).

FAO (Food and Agriculture Organization).(2015). FAOSTAT database. (available at: http://www.fao.org/FAOSTAT/en/).

Gardner, B. L. (1975). The farm-retail price spread in a competitive food industry. American Journal of Agricultural Economics, 57(3), 399-409.

Haile, Mekbib .G., M. Kalkuhl and J. von Braun. (2014). Short-term global crop acreage response to international food prices and implications of volatility. ZEF- Discussion Paper on Development Policy no.175.

Haile, M. G., Kalkuhl, M., \& Von Braun, J. (2015). Worldwide Acreage and Yield Response to International Price Change and Volatility: A Dynamic Panel Data Analysis for Wheat, Rice, Corn, and Soybeans. American Journal of Agricultural Economics, aav013.

Hall, R. E., \& Jones, C. I. (1997). Levels of Economic Activity across Countries. American Economic Review, 87(2), 173-77.

Hall, R. E., \& Jones, C. I. (1999). Why Do Some Countries Produce So Much More Output Per Worker Than Others? The Quarterly Journal of Economics, 114(1), 83-116.

Helleiner, G. (1975). Smallholder Decision Making: Tropical African Evidence, Chap. 2 in Agriculture in Development Theory, ed. by Lloyd G. Reynolds (Yale University Press, 1975), pp. 27-52

Hendricks, N. P., Janzen, J. P., \& Dhuyvetter, K. C. (2012). Subsidy incidence and inertia in farmland rental markets: estimates from a dynamic panel. Journal of Agricultural and Resource Economics, 37(3), 361.

Imai, K. S., Gaiha, R., \& Thapa, G. (2011). Supply response to changes in agricultural commodity prices in Asian countries. Journal of Asian Economics, 22(1), 61-75.

Key, N., Sadoulet, E., \& De Janvry, A. (2000). Transactions costs and agricultural household supply response. American journal of agricultural economics, 82(2), 245-259.

Knack, S and Keefer, P. (1995). Institutions and economic performance: cross-country tests using alternative institutional measures. Economics and Politics 7, 207- 227.

Keefer, P and Knack, S. (1997). Why don't poor countries catch up? A cross-national test of an institutional explanation. Economic Inquiry 35, 590-602.

Kherallah, M. D., Gabre-Madhin, C., \& Minot, E. N, Johnson, M. 2002. Reforming Agricultural Markets in Africa. Food Policy statement, 38.

Krueger, A. O., M. Schiff, and A. Valdés, eds. (1991). The Political Economy of Agricultural Pricing Policy. Volume 3: Africa and the Mediterranean. Washington: The World Bank.

Lansink, A. O. (1999). Area allocation under price uncertainty on Dutch arable farms. Journal of Agricultural Economics, 50(1), 93-105.

Leaver R (2004). Measuring the supply response function of tobacco in Zimbabwe. Agrekon, 43:113129.

MAFAP. (2015). MAFAP Methodological paper: Volume I. Analysis of price incentives. MAFAP Technical Notes Series, FAO, Rome, Italy

Mamingi, N., (1997.) The impact of prices and macroeconomic policies on agricultural supply: a synthesis of available results. Agricultural Economics 16, 17-34.

McKay, A., O. Morissey, and C. Vaillant (1998). Aggregate Supply Response in Tanzanian Agriculture. The Journal of International Trade and Economic Development 8: 107-124. 
Meyer, J., and S. von Cramon-Taubadel. (2004). Asymmetric Price Transmission: a Survey. Journal of Agricultural Economics 55 (3): 581-611.

Mkpado, M., Arene, C. J., \& Chidebelu, S. (2012). Hectarage Response of Rice Production to Market Liberalisation and Price Risk in Nigeria. Economic Affairs, 57(1), 73-89.

Molua, E. L. (2010). Price and non-price determinants and acreage response of rice in Cameroon. ARPN Journal of Agricultural and Biological Science, 5(3), 20-25.

Muchapondwa, E. (2009). Supply response of Zimbabwean agriculture: 1970-1999. African Journal of Agricultural and Resource Economics, 3(1), 28-42.

Nerlove, M. (1956). Estimates of the elasticities of supply of selected agricultural commodities. Journal of Farm Economics, 38(2), 496-509.

Nerlove, M. (1958). Adaptive Expectations and Cobweb Phenomena. The Quarterly Journal of Economics 72 (2): 227-40.

Nickell, S. (1981). Biases in dynamic models with fixed effects. Econometrica, 1417-1426

Nin-Pratt, A., B. Yu and S. Fan. 2008. Total factor productivity in Chinese and Indian agriculture: Measures and determinants. China Agricultural Economic Review 1(1): 9-22.

Onal, A. (2012). An empirical analysis of supply response for selected export crops in Sub-Saharan Africa. African Agricultural Reforms, 89.

Oyejide, T.A. 1990. Supply response in the context of structural adjustment in sub-Saharan Africa". AERC Special Paper 1 Nairobi: Initiatives Publishers.

Parrot S D., and CS. Mcintosh. (1996). "Non-constant Price Expectations and Acreage ' Response: The Case of Cotton Producfion in Georgia." Journal of Agricultural and Applied Economics. 28: 203-212

Poulton, C., Kydd, J., and Dorward, A. (2006). Overcoming market constraints on pro-poor agricultural growth in sub-Saharan Africa. Development Policy Review, 24(3), 243-277.

Rao, J. M. (1989). Agricultural supply response: A survey. Agricultural economics, 3(1), 1-22.

Rapsomanikis, G., Hallam, D., \& Conforti, P. (2006). Market integration and price transmission in selected food and cash crop markets of developing countries: review and applications. SARRIS, A. AND D. HALLAM: Agricultural Commodity Markets and Trade, Edward Elgar, Cheltenham, UK, 187217.

Roberts, M. J., \& Schlenker, W. (2009). World supply and demand of food commodity calories. American Journal of Agricultural Economics, 91(5), 1235-1242.

Roberts, M. J., \& Schlenker, W. (2013). Identifying Supply and Demand Elasticities of Agricultural Commodities: Implications for the US Ethanol Mandate. The American Economic Review, 103(6), 2265-2295.

Rojas, O., Vrieling, A., \& Rembold, F. (2011). Assessing drought probability for agricultural areas in Africa with coarse resolution remote sensing imagery. Remote Sensing of Environment, 115(2), 343-352.

Roodman, D. (2009a). How to do xtabond2: An introduction to difference and system GMM in Stata. Stata Journal, 9(1), 86-136.

Roodman, D. (2009b). A note on the theme of too many instruments*. Oxford Bulletin of Economics and statistics, 71(1), 135-158.

Saghir, J. (2014). Global challenges in agriculture and the World Bank's response in Africa. Food and Energy Security, 3(2), 61-68.

Short, C; Barreiro-Hurle, J; Balié, J. Policy or Markets? (2014). An Analysis of Price Incentives and Disincentives for Rice and Cotton in Selected African Countries. Canadian Journal of Agricultural Economics/Revue canadienne d'agroéconomie. IS - 4 SN - 1744-7976

Schiff, M., and C. Montenegro (1997). Aggregate Agricultural Supply Response in Developing Countries: A Survey of Selected Issues. Economic Development and Cultural Change 45: 393-410. 
Svendsen, M., Trava, J. and Johnson III, S.H. (2007) Participatory Irrigation Management: Benefits and Second Generation Problems. Lessons from an International Workshop Held at Centro Internacional de Agricultura Tropical (CIAT) Cali, Colombia, 9-15 February, 1997. Economic Development Institute of the World Bank and International Institute for the Management of Irrigation, Washington, DC.

Subervie, J. (2008). The variable response of agricultural supply to world price instability in developing countries. Journal of Agricultural Economics, 59(1), 72-92.

Thiele, R. (2003). Price incentives, Non-Price Factors and Agricultural Production in Sub Saharan Africa: A Cointegration Analysis". African Development Review, 15(2-3), 425-438.

Townsend, R .(1999). Agricultural Incentives in Sub-Saharan Africa. World Bank Technical Paper 444.Washington Dc.

Vitale, J. D., Djourra, H., \& Sidib, A. (2009). Estimating the supply response of cotton and cereal crops in smallholder production systems: recent evidence from Mali. Agricultural Economics, 40(5), 519533.

Weersink, A., Cabas, J. H., \& Olale, E. (2010). Acreage Response to Weather, Yield, and Price. Canadian Journal of Agricultural Economics/Revue canadienne d'agroeconomie, 58(1), 57-72.

Windmeijer, F. (2005). A finite sample correction for the variance of linear efficient two-step GMM estimators. Journal of econometrics, 126(1), 25-51.

World Bank. (1994). Adjustment in Africa: Reforms, Results, and the Road Ahead. New York: Oxford University Press, 1994. 284 pp.

World Bank. (2008). Double Jeopardy: Responding to High Food and Fuel Prices. G8 HokkaidoTokayo Summit. Japan, World Bank.

World Bank (2012). Africa can help feed Africa: removing barriers to regional trade in food staples.

World Bank (2015). World Development Indicators. Database online.

Yu, B., Liu, F., \& You, L. (2012). Dynamic Agricultural Supply Response Under Economic Transformation: A Case Study of Henan, China. American Journal of Agricultural Economics, 4(2), 370-376. 


\subsection{Appendices}

Table 16: Data Sources for producer, wholesale, border prices and marketing costs

\section{Country}

Institution

Link

\begin{tabular}{|c|c|c|}
\hline Burkina Faso & Ministère de l'Agriculture de l'Hydraulique et des Recherches Halieutiques & http://www.agriculture.gov.bf/ \\
\hline Ethiopia & Ethiopian Development Research Institute & http://www.edri.org.et/ \\
\hline Ghana & Ministry of Food and Agriculture & http://www.mofa.gov.gh/ \\
\hline Kenya & Kenya Agicultural and Livestock Research Organization & not available \\
\hline Malawi & Ministry of Agriculture and Food Security & http://www.malawi.gov.mw/ \\
\hline Mali & Institut d'Economie Rurale & http://www.ier.gouv.ml/ \\
\hline Mozambique & Ministro da Agricultura e Segurança Alimentar & http://www.masa.gov.mz/ \\
\hline Nigeria & Federal Ministry of Agriculture/National Bureau of Statistics & http://www.fmard.gov.ng \\
\hline Uganda & Ministry of Agriculture, Animal Industry and Fisheries & http://www.agriculture.go.ug/ \\
\hline Tanzania & Ministry of Agriculture Food Security and Cooperatives & http://www.agriculture.go.tz/ \\
\hline
\end{tabular}




\begin{tabular}{|c|c|c|c|c|c|c|c|c|c|c|c|}
\hline & & Burkina Faso & Ethiopia & Ghana & Kenya & Malawi & Mali & Mozambique & Nigeria & Uganda & Tanzania \\
\hline \multirow{2}{*}{ Area } & Mean & 13.01 & 13.84 & 13.00 & 12.10 & 14.28 & 13.61 & 13.41 & 15.26 & 11.89 & 14.30 \\
\hline & SD & 1.31 & 0.76 & 0.76 & 1.45 & 0.11 & 0.57 & 1.06 & 0.58 & 1.69 & 0.74 \\
\hline \multirow{2}{*}{ Production } & Mean & 13.42 & 14.34 & 14.57 & 13.08 & 14.89 & 14.00 & 13.99 & 15.61 & 12.99 & 14.76 \\
\hline & SD & 1.04 & 1.01 & 1.34 & 1.38 & 0.35 & 0.35 & 1.62 & 0.44 & 2.21 & 0.54 \\
\hline \multirow{2}{*}{ Yield } & Mean & 9.62 & 9.71 & 10.78 & 10.19 & 9.82 & 9.60 & 9.79 & 9.55 & 10.32 & 9.67 \\
\hline & SD & 0.34 & 0.30 & 1.00 & 1.25 & 0.35 & 0.58 & 1.00 & 0.20 & 0.86 & 0.26 \\
\hline \multirow{2}{*}{ FG Price } & Mean & 11.72 & 8.23 & 5.87 & 10.03 & 9.87 & 11.83 & 8.69 & 10.26 & 13.24 & 13.12 \\
\hline & SD & 0.20 & 0.29 & 0.75 & 0.44 & 0.38 & 0.44 & 0.43 & 0.15 & 0.47 & 0.63 \\
\hline \multirow{2}{*}{ WS Price } & Mean & 11.99 & 8.39 & 6.21 & 10.34 & 10.62 & 12.05 & 9.08 & 11.26 & 13.53 & 13.37 \\
\hline & SD & 0.13 & 0.25 & 0.81 & 0.45 & 0.32 & 0.40 & 0.49 & 0.47 & 0.59 & 0.57 \\
\hline \multirow{2}{*}{ NCP } & Mean & 0.83 & 0.70 & 0.71 & 1.22 & 0.57 & 0.77 & 0.60 & 0.45 & 0.84 & 1.07 \\
\hline & SD & 0.28 & 0.30 & 0.48 & 0.62 & 0.08 & 0.35 & 0.30 & 0.13 & 0.29 & 0.43 \\
\hline \multirow{2}{*}{ RER } & Mean & 497.40 & 13.78 & 1.47 & 86.75 & 172.46 & 501.51 & 30.01 & 163.65 & 2138.26 & 1425.36 \\
\hline & SD & 31.66 & 2.05 & 0.08 & 16.27 & 28.19 & 34.34 & 2.69 & 14.03 & 159.19 & 127.38 \\
\hline \multirow{2}{*}{ BP } & Mean & 5.74 & 6.06 & 6.12 & 5.50 & 5.30 & 5.99 & 5.97 & 6.01 & 5.79 & 5.87 \\
\hline & SD & 0.27 & 0.26 & 0.38 & 0.69 & 0.25 & 0.40 & 0.37 & 0.37 & 0.29 & 0.44 \\
\hline \multirow{2}{*}{ Market Cost } & Mean & 11.61 & 7.69 & 6.10 & 9.37 & 9.85 & 11.38 & 8.80 & 10.66 & 12.81 & 12.14 \\
\hline & SD & 0.37 & 0.32 & 0.68 & 0.54 & 0.00 & 0.26 & 0.55 & 0.53 & 0.53 & 0.39 \\
\hline \multirow{2}{*}{ PPI } & Mean & 1.31 & 2.26 & 1.70 & 1.40 & 1.73 & 1.32 & 2.18 & 1.42 & 2.12 & 1.50 \\
\hline & SD & 0.21 & 0.93 & 0.53 & 0.38 & 0.60 & 0.35 & 0.92 & 0.41 & 0.73 & 0.47 \\
\hline \multirow{2}{*}{ Y. Shock } & Mean & 0.08 & -0.05 & -0.30 & -0.06 & -0.03 & 0.17 & -0.62 & 0.20 & 0.00 & -0.04 \\
\hline & SD & 1.12 & 0.91 & 1.36 & 1.32 & 1.22 & 1.35 & 3.06 & 1.63 & 1.20 & 0.92 \\
\hline \multirow{2}{*}{ ASI } & Mean & 0.05 & 0.12 & 0.02 & 0.14 & 0.02 & 0.03 & 0.04 & 0.03 & 0.10 & 0.11 \\
\hline & SD & 0.08 & 0.06 & 0.02 & 0.14 & 0.03 & 0.04 & 0.04 & 0.04 & 0.10 & 0.16 \\
\hline \multirow{2}{*}{ Oil Price } & Mean & 0.61 & 0.42 & 0.49 & 0.60 & 0.50 & 0.63 & 0.49 & 0.58 & 0.41 & 0.62 \\
\hline & SD & 0.09 & 0.15 & 0.14 & 0.11 & 0.10 & 0.13 & 0.13 & 0.14 & 0.12 & 0.11 \\
\hline
\end{tabular}

Note: Area, Production, Yield, FG Price, WS Price, Border Price, Marketing Costs and Real Oil Price are expressed in logarithmic form. 


\begin{tabular}{|c|c|c|c|c|}
\hline & \multirow{2}{*}{\multicolumn{2}{|c|}{$\begin{array}{c}\text { Im-Pesaran-Shin } \\
\text { H0: Non-stationarity }\end{array}$}} & \multirow{2}{*}{\multicolumn{2}{|c|}{$\begin{array}{c}\text { Fisher (ADF) - Inverse Chi Square } \\
\text { H0: Non-stationarity }\end{array}$}} \\
\hline & & & & \\
\hline & Level & Difference & Level & Difference \\
\hline Production & 0.182 & 0.000 & 0.967 & 0.000 \\
\hline Area & 0.097 & 0.000 & 0.995 & 0.000 \\
\hline Yield & 0.000 & 0.000 & 0.000 & 0.000 \\
\hline FG Price & 0.000 & 0.000 & 0.000 & 0.000 \\
\hline WS Price & 0.001 & 0.000 & 0.000 & 0.000 \\
\hline NCP & 0.000 & 0.000 & 0.000 & 0.000 \\
\hline Real Exchange Rate & 0.013 & 0.000 & 0.007 & 0.000 \\
\hline Border Price & 0.000 & 0.000 & 0.000 & 0.000 \\
\hline Marketing Cost & 0.000 & 0.000 & 0.000 & 0.000 \\
\hline Producer Price Index & 1.000 & 0.000 & 1.000 & 0.000 \\
\hline Agricultural Stress Index & 0.000 & 0.000 & 0.000 & 0.000 \\
\hline Real Oil Price & 0.397 & 0.000 & 0.951 & 0.010 \\
\hline Yield Shock & 0.000 & 0.000 & 0.000 & 0.000 \\
\hline
\end{tabular}




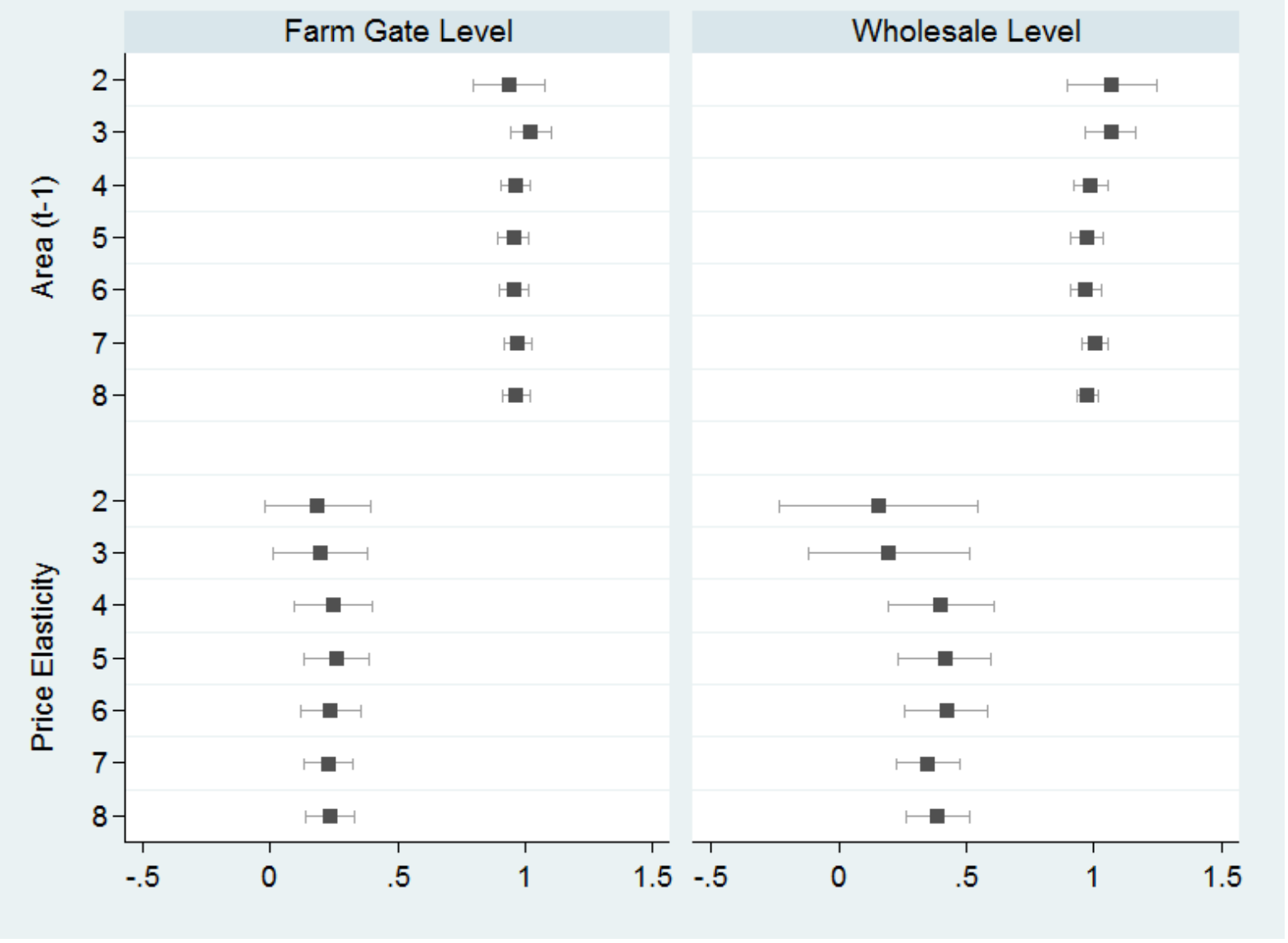

Note: Figure reports the lagged area and price elasticity coefficient estimates using alternative maximum number of lags to be used as instruments. The point estimates and the $90 \%$ confidence interval are obtained using the two-step system-GMM estimates described in table 13. 


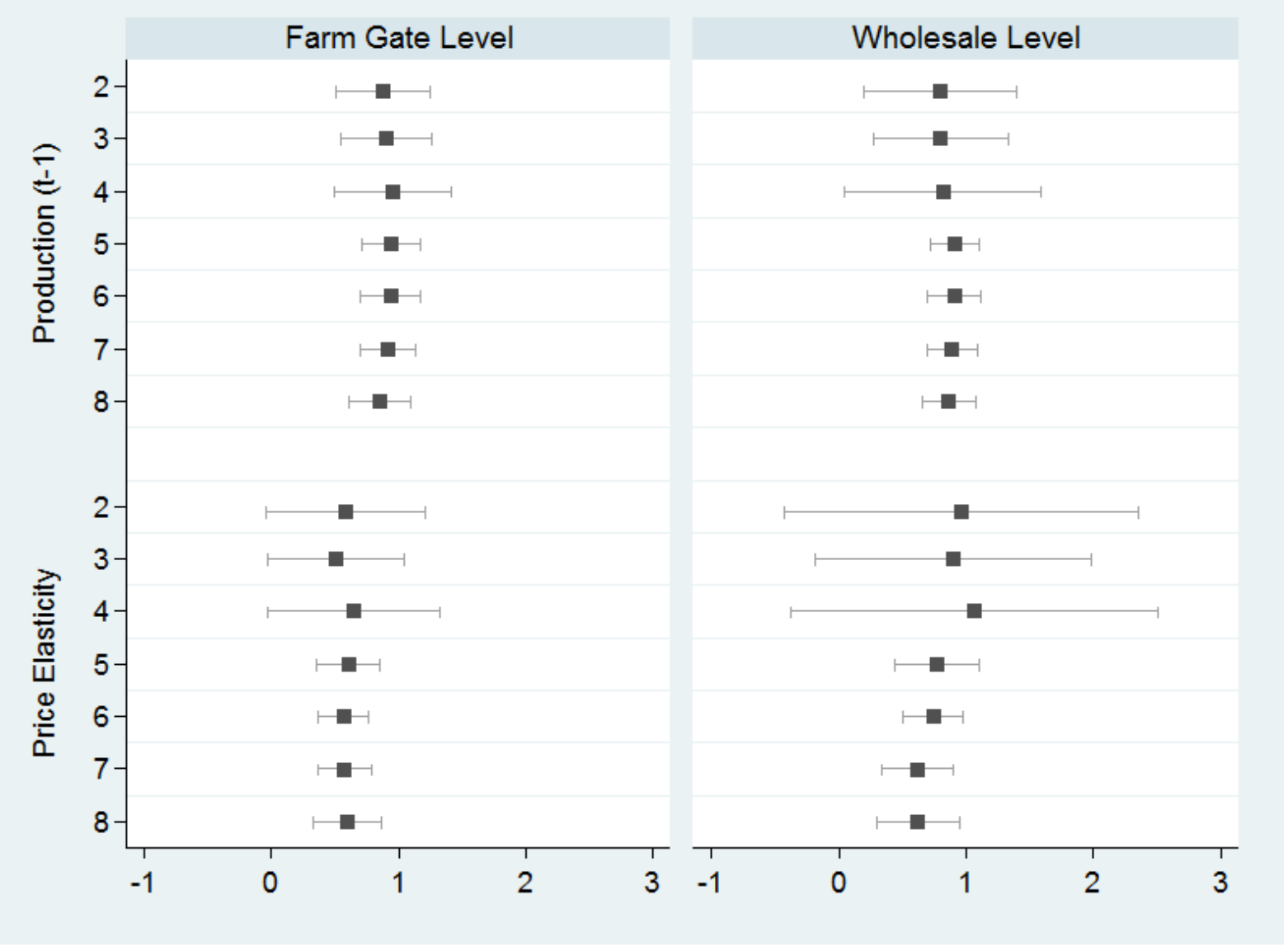

Note: Figure reports the lagged production and price elasticity coefficient estimates using alternative maximum number of lags to be used as instruments. The point estimates and the $90 \%$ confidence interval are obtained using the two-step system-GMM estimates described in table 14 . 


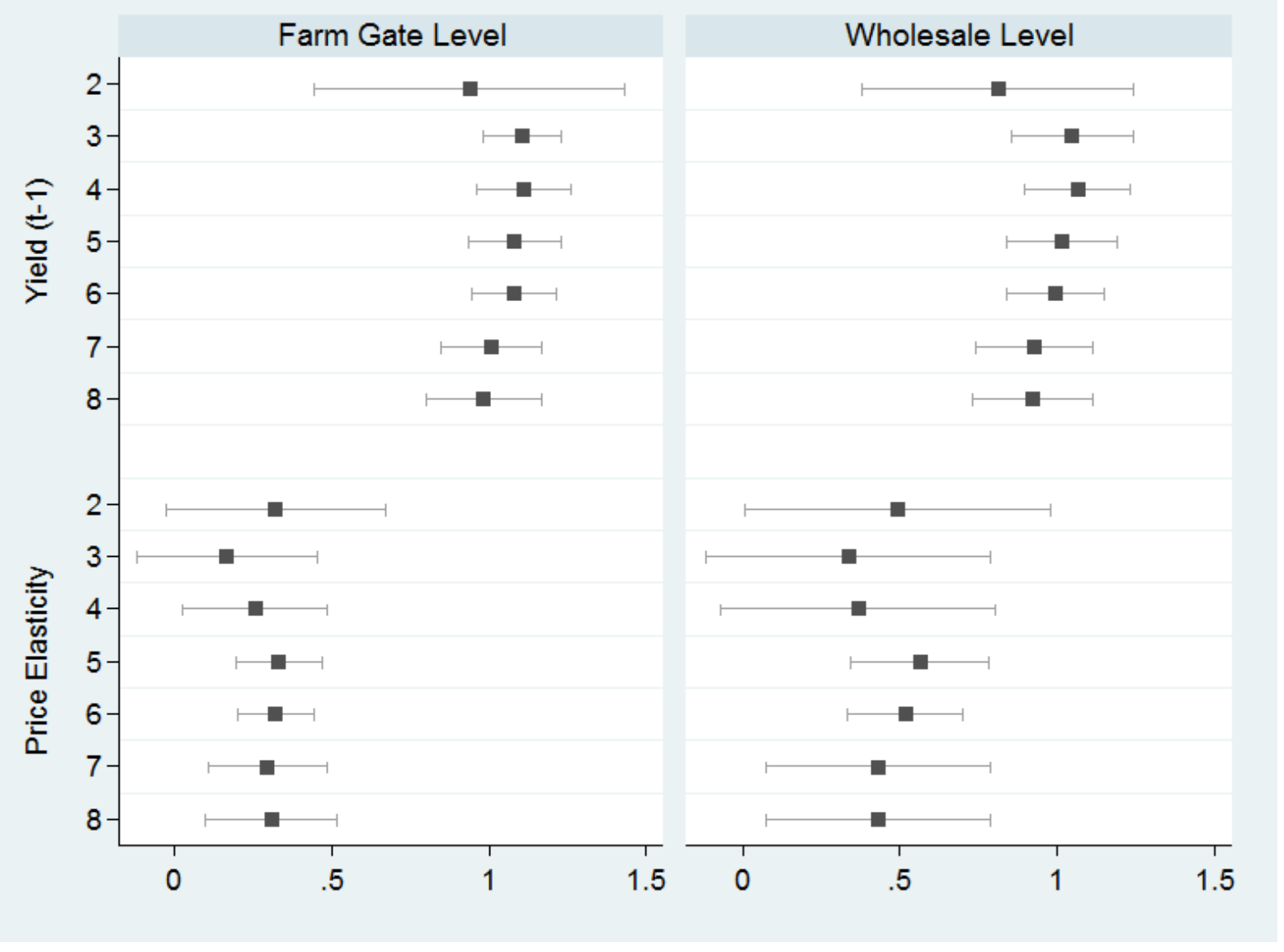

Note: Figure reports the lagged yield and price elasticity coefficient estimates using alternative maximum number of lags to be used as instruments. The point estimates and the $90 \%$ confidence interval are obtained using the two-step system-GMM estimates described in table 15. 


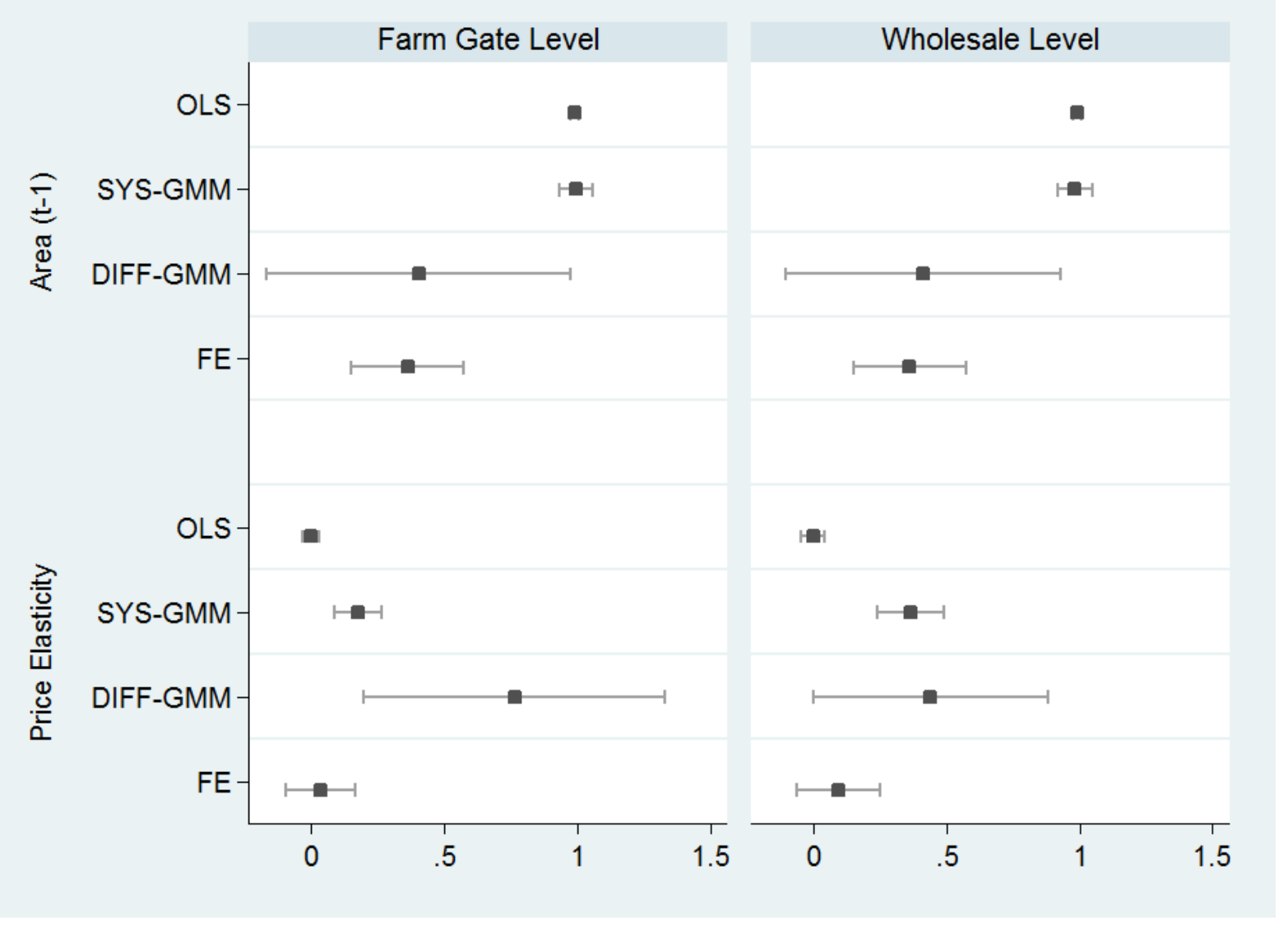

Notes: Ordinary Least Square (OLS) and Fixed Effect (FE) regressions are calculated using robust standard errors clustered by country-commodity. Two-step system-GMM (SYS-GMM) and difference-GMM (DIFF-GMM) regressions use robust standard errors with Windmeijer (2005) finite sample correction and treat the lagged dependent variable and the price elasticity as predetermined. The instrument matrices in the GMM models are collapsed. 


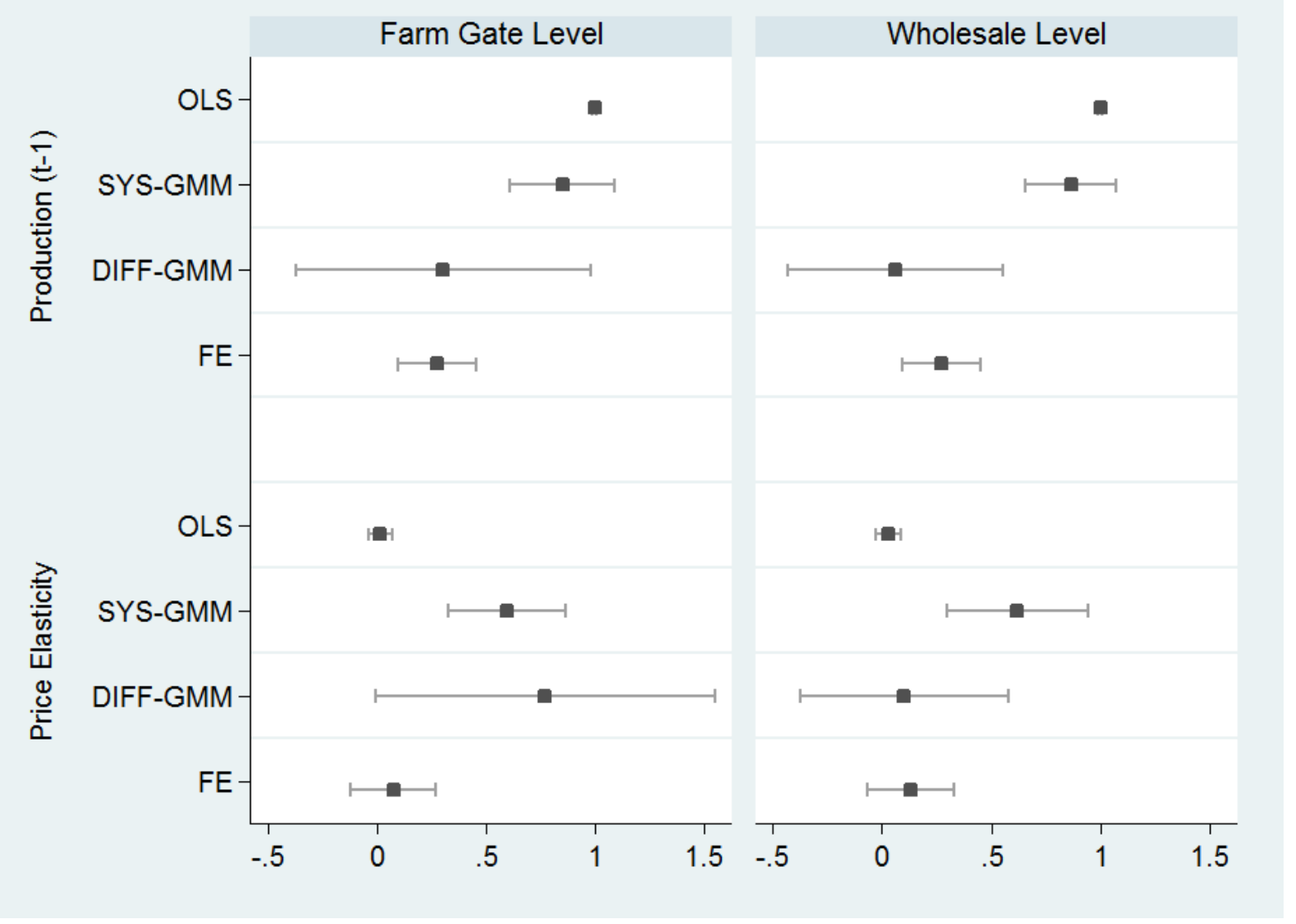

Notes: Ordinary Least Square (OLS) and Fixed Effect (FE) regressions are calculated using robust standard errors clustered by country-commodity. Two-step system-GMM (SYS-GMM) and difference-GMM (DIFF-GMM) regressions use robust standard errors with Windmeijer (2005) finite sample correction and treat the lagged dependent variable and the price elasticity as predetermined. The instrument matrices in the GMM models are collapsed. 


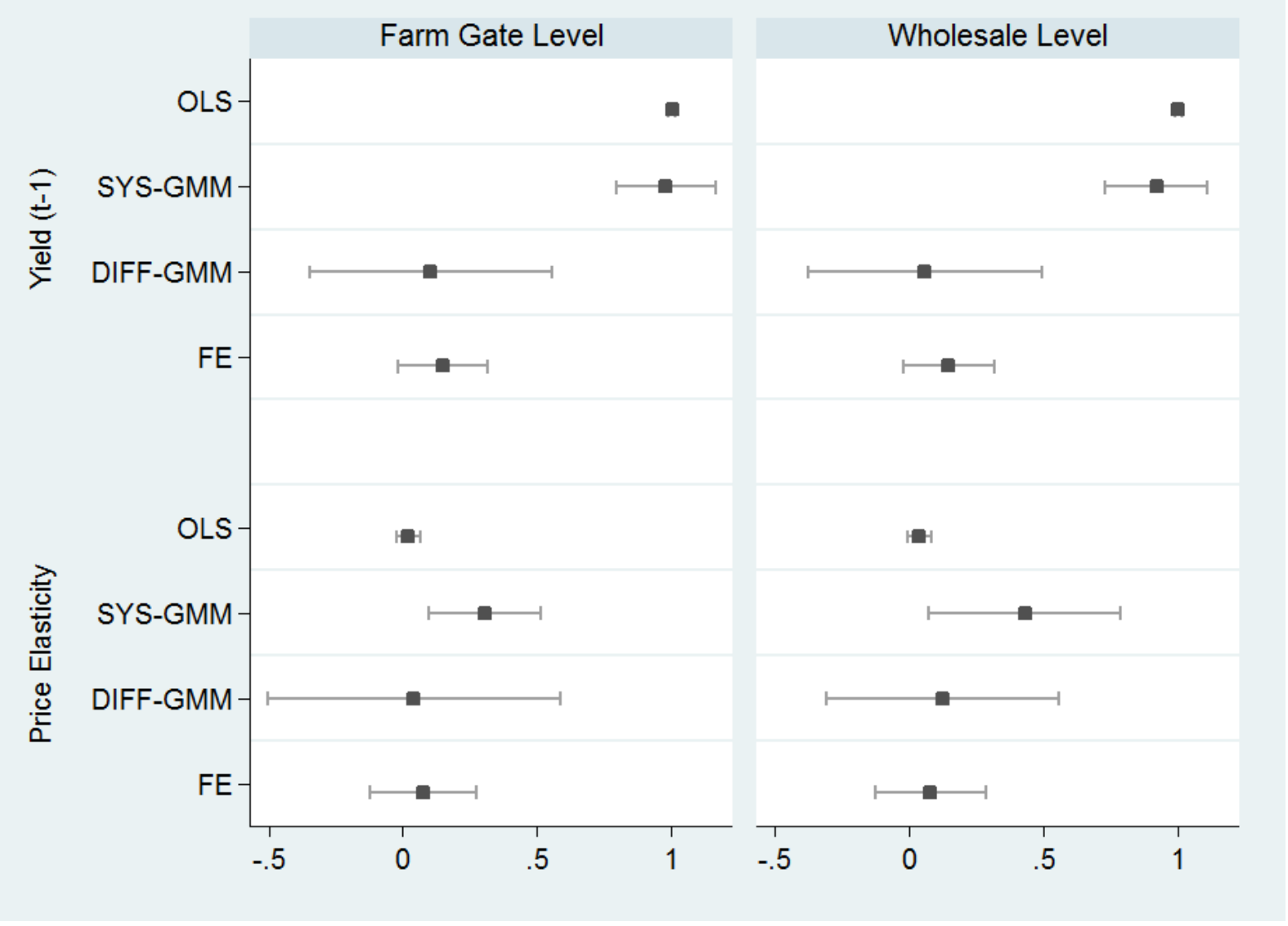

Notes: Ordinary Least Square (OLS) and Fixed Effect (FE) regressions are calculated using robust standard errors clustered by country-commodity. Two-step system-GMM (SYS-GMM) and difference-GMM (DIFF-GMM) regressions use robust standard errors with Windmeijer (2005) finite sample correction and treat the lagged dependent variable and the price elasticity as predetermined. The instrument matrices in the GMM models are collapsed. 


\section{Discussion}

The food and agricultural policies adopted by governments in Sub Saharan Africa (SSA) since their respective independences have gone through a number of phases characterized by changing objectives, intensities of state intervention in the economy, levels of protection or taxation in agriculture, and amounts of public spending and aid to agriculture (Balié and Maetz, 2011). There was no systematic tracking of these changes and their implications for agricultural development and rural transformation, poverty eradication and food security, for example.

Following a first experiment by Krueger, Schiff and Valdes (1988), the research project led by Kym Anderson (Anderson and Kurzweil, 2008; Anderson and Nelgen, 2012) bridged this gap in the literature by estimating distortions to agricultural incentives in a large number of developing countries. More recently, the FAO implemented the Monitoring and Analyzing Food and Agricultural Policies (MAFAP) programme with the objective, among others, to update and further develop this kind of dataset. In particular, the MAFAP programme seeks to establish country-owned and sustainable systems to monitor, analyze, and reform food and agricultural policies to enable more effective, efficient and inclusive policy frameworks in a growing number of developing and emerging economies. In that sense, the MAFAP project tries to more sustainably bridge this information and capacity gap.

The various chapters of this dissertation build on data and results of the MAFAP programme.

Chapter 2 concludes that policies adopted by governments, for example, in response to price shocks in international markets alter the transmission of international price signals to farmers in developing countries. We also find that other factors play a role in this inadequate price transmission such as transport costs, changes in exchange rates, for example. Moreover, it also appears that the price changes in any particular country are not necessarily due to changes in world market prices, which suggests that domestic market conditions, largely determined by the policy environment, play an essential role. Finally, we also find that price movements in Africa exhibit different patterns than those in other regions with higher level of price variability for maize and rice mostly due to domestic market conditions.

Chapter 3 investigates the case of rice and cotton which are two key commodities for several SSA countries and concludes that observed market distortions reflect the combined effects of market and policy failures. In the case of rice, these prevent border protection from reaching farmers while raising consumer prices. Cotton ginning and marketing is concentrated in a small number of private sector companies in most countries studied. The farm-level nominal rates of protection (NRPs) provide evidence of market failures in these countries that may be mitigated by policies that set indicative prices and encourage competition. Interestingly, the NRPs point at non-market failures in the two countries that maintain parastatal monopsonies for cotton.

Chapter 4 finds that input subsidies can be seen as a peculiar option of public support to agricultural production. Input subsidies account for close to $35 \%$ of agricultural-specific spending on average. Furthermore, these expenditures tended to get stuck into agricultural budgets over time and exhibit suboptimal execution rates. Input subsidies are primarily funded by national taxpayer money while donors tend to invest more on public goods. These findings confirm that input subsidies tend to crowd out other spending categories likely more supportive of long-term agricultural development objectives.

Page | 117 
Chapter 5 explores the effects of market price signals and policy interventions on the supply response of farmers in SSA and find that farmers in SSA are actually able to respond to higher prices with increased production even if with a limited intensity. Moreover, results show that direct price incentives arising from border protection and government intervention in domestic markets and price shocks at the border also influence farmers' decisions and are more important than macroeconomic policies. Moreover, omitting marketing costs from the supply response function leads to an underestimation of the price elasticity. Conversely, using wholesale instead of farm gate prices as proxy for producer prices leads to an overestimation of the price elasticity of supply.

As seen throughout the chapters, government interventions in markets are pervasive. In the literature, it has often been argued that direct government intervention can be justified to overcome market failures or is needed in the early stages of agricultural development when conditions are less favourable (Dorward, Kydd and Poulton, 2007; Barret, 2008; Brooks, 2010). The challenge is then to find sets of policy instruments which minimize some of the highly undesirable consequences of intervention, rather than to regard these consequences as sufficient reasons in themselves for excluding any form of price intervention (Howell 2005; Devereux 2009).

Recent MAFAP updates of the NRPs in 11 African countries ${ }^{53}$ between 2005 and 2013 show that countries still intervene extensively in their agricultural sector through policies which distort markets as well as investment efforts. These policy decisions include a wide spectrum of policy measures ranging from highly distortive administered producer or consumer prices, to border protection or export restrictions, to slightly less distortive inputs subsidies, and more WTO-compatible types of direct or indirect transfers to agents or groups of economic agents to support marketing, research, extension, infrastructures (feeder roads, storage facilities, etc. ).

In the countries studied, there is an apparent gradual convergence towards an average protection of farmers slightly above zero and trending around five percent under regular market conditions (Figure 25). This suggests that on average the extent of distortions in output markets tends to diminish over time with a progressive evolution from a situation of net taxation to a stabilization at a very moderate level of protection on average for the countries studied. However, the wide bounds of the $1 \mathrm{st}$ and $3 \mathrm{~d}$ quartiles of Figure 25 indicate that the average NRP hides substantial heterogeneity across countries. This is likely the consequence of various ad-hoc trade restrictions, price policies, parastatal intervention, fluctuating budget execution rates and a volatile investment climates. Moreover, two episodes of negative average incentives can be observed around 2010 and 2013 due to strong international market movements and domestic market rigidities that protected domestic markets to the detriment of farmers.

53 Burkina Faso, Burundi, Ethiopia, Ghana, Kenya, Malawi, Mali, Mozambique, Tanzania, Uganda, and Senegal 
Figure 25: Average Nominal Rate of protection in 11 Sub Saharan Countries

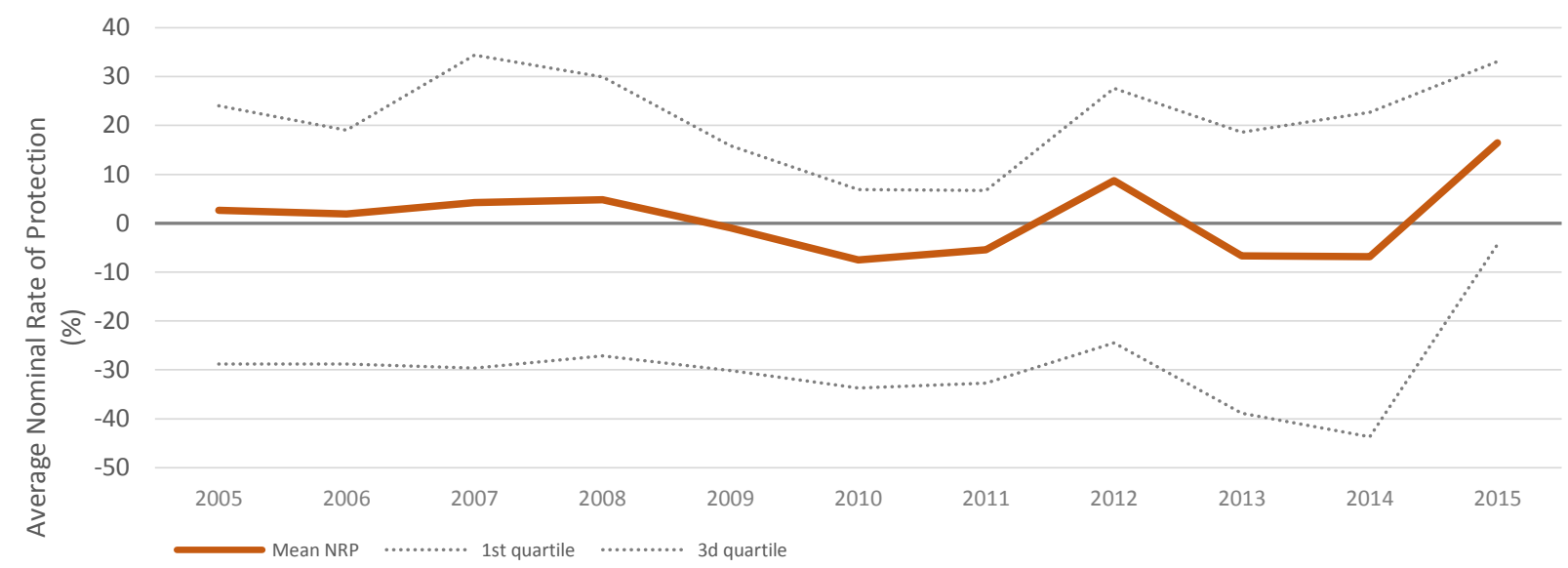

Source: author based on MAFAP data, 2016

Burkina Faso, and Tanzania, Uganda,

In Figure 26, we report the NRP changes between years 2005-09 and 2010-14. Overall, we observe that with a few exceptions the pattern of distortions has not substantially changed in the last decade. While a few countries exhibit lower level of incentives in 2010-14 compared with 2005-09, others have either witnessed a change in sign or increased disincentives. Changes for some countries are worth noting. Burkina Faso and Kenya are the only countries that increased the level of incentives although this increase is moderate in the case of Burkina Faso and larger for Kenya. Four countries have actually reduced their incentives over time including Senegal, Tanzania, Uganda, and to a much lesser extent Burundi, where incentives basically remained unchanged. Tanzania can also be seen as an outlier given its relatively high level of support throughout the period analyzed. Ghana appears to be the only country that moved from substantial disincentives to a situation of moderate price incentives while Mozambique evolved in the opposite direction with much more pronounced price disincentives for the 2010-14 period. Ethiopia, Malawi, and Mali maintained substantial price disincentives with the situation actually worsening in Malawi and Mali over time.

Overall, heterogeneity prevails in the group of countries studied. As already discussed above, these results appear to be quite volatile over time and prone to trend reversal as a result of changing modalities and depth of policy interventions. Sustaining efforts for a systematic measurement of these policy effects appears necessary in the medium /long run to make the policy environment more conducive to emergence of efficient markets and effective food systems in SSA. 


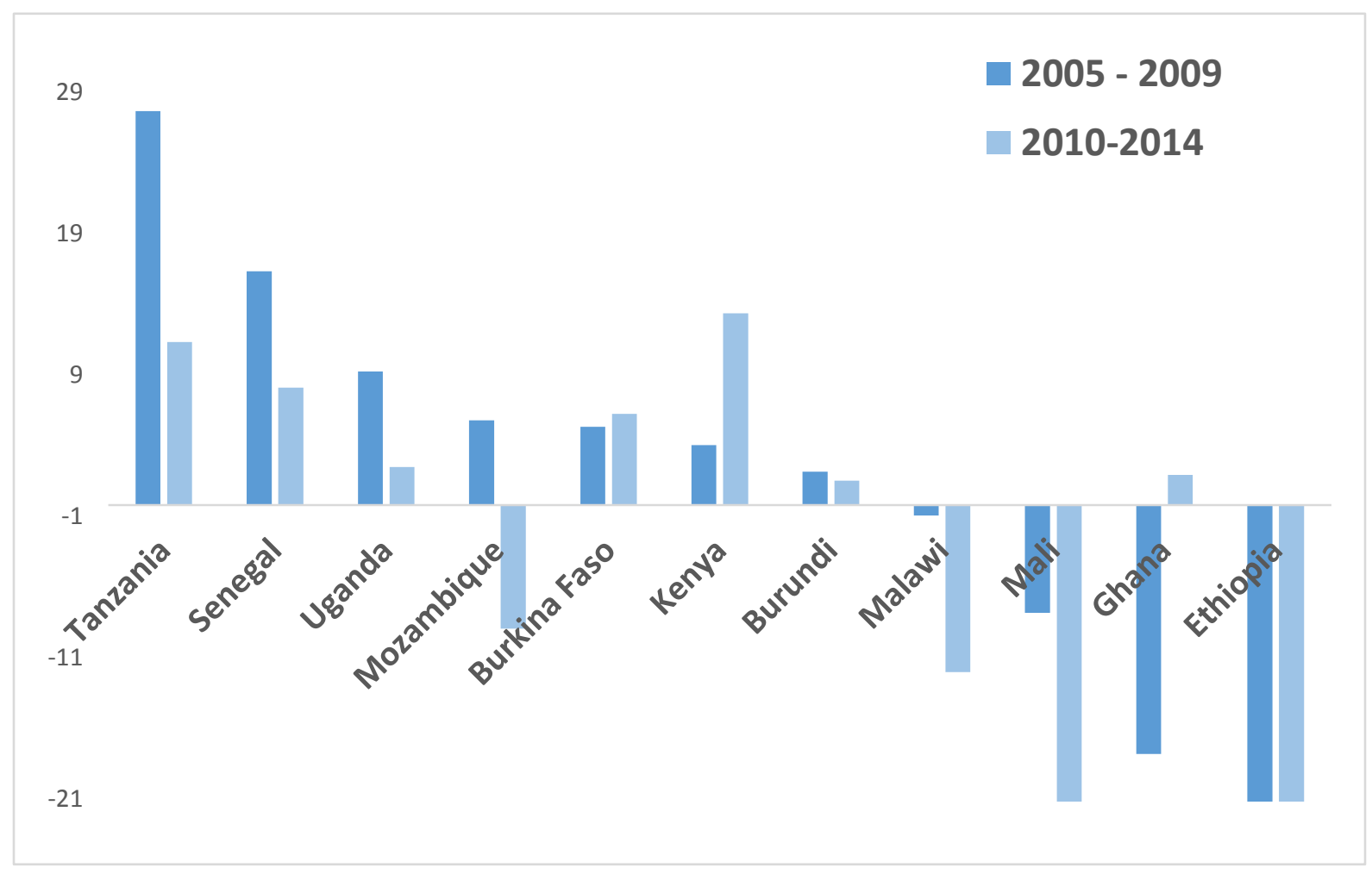

Source: author based on MAFAP data, 2016

It was already pointed out that the type of government intervention matters a lot because some instruments are more distortive than others (see chapters 2, 3, 4, and 5). Those that affect agents directly including producers, consumers, and other agents along the value chain are more likely to distort markets than the "general sector" categories of spending such as research, training, or budget outlays in support of rural development more generally. While trade and price policies are recognized as potentially highly distortive of market price signals, we find that these distorted market signals may also result from various forms of market failures (chapters 2, 3 and 5). They often translate into excessive marketing costs incurred by economic agents and primarily farmers in getting goods to markets because of poor infrastructures or obsolete processing technology, and by malfunctioning markets resulting, for example, from monopolistic (or monopsonistic) practices and rent capturing that may be observed along the value chain (Omamo, 1998; Shepherd, 2007). The finding of the important role played by marketing margins (chapter 3 and chapter 5 in particular) in the production function echoes the role attributed to the market failures in various sections of this dissertation. As substantial price distortions and market imperfections pervade the agricultural sector across SSA economies, there appears to be ample scope to measure and monitor not only the effects of explicit policy support but also the effects of implicit policies in the build-up of the price wedges at producer level in particular.

As suggested in chapter 2, domestic prices of specific commodities adjust more or less rapidly to changing conditions in international markets due to domestic policy effects but also because markets are less integrated as a result of market failures (Getnet et al., 2005; Hazell et al., 2010). As we have seen in chapter 
3 , because in some areas or specific value chains traders can exercise market power, farmers will end up receiving lower prices for their products or paying more for the inputs they purchase (Ebata et al., 2015).

In one recent study, Shimeles et al. (2015) examine the fertilizer retail-import price gap in 14 African countries between 2002 and 2013. They find that the price differential is generally large even after taking into account domestic transport costs. They explain that these price deviations indicate market power by importers/suppliers which are the result of a lack of competition accepted by governments in exchange for political rent. Overall, they conclude that market imperfections and inefficiencies are linked to the quality of the regulatory and policy environment in Africa.

Similarly, Figure 11 in chapter 3 reports distribution of observed and theoretical values of NRPs for rice and points at a combination of market and policy failures as one of the key explanations for excessive distortions of price signals at farm level. Distortions between the wholesale market and the farm gate more than offset the protection between the border and wholesale and result in a net taxation effect for farmers.

These examples suggest that it is important for governments in SSA to invest in public goods such as infrastructures (Jacoby, 2000, World Bank, 2007). In SSA like in other developing regions, such public investments appear necessary to reduce the bulk of agricultural production disincentives that farmers face (Mérel et al., 2009). For instance, recognizing that farm-gate prices are also determined by distance to markets as well as traveling time (Ebata et al., 2015), policy makers may value information on alternative interventions and compare potential payoffs of an investment in rural roads to reduce transportation costs relative to a change in trade policy, for example (Jacoby and Minten, 2009).

Conceptually, this set of costs due to market power, lack of public goods provision, obsolete technologies and the like, results in an additional price wedge and could be referred to as a "market development gap". Arguments abound in favour of a systematic measurement of such a market development gap. However, as we have seen throughout this dissertation, while an abundant literature exists on measuring the effects of price and trade policies on agricultural commodities since the seminal work by Krueger, Schiff and Valdes (1991) followed by the assessment of distortions to agricultural incentives (Anderson, 2009), much less empirical analysis is available on the effects of market failures on production disincentives. This is most likely due to the difficulty of disentangling the effects of explicit policy instruments from other factors that influence price levels. In addition, this topic is much less relevant for high income countries where most of the OECD-type policy measurement work has been carried out. Important challenges related to data scarcity in developing countries as well as methodological options have also prevented researchers from further investigating this topic.

In future empirical research, there seems to be a need to identify the major sources of market development gaps in African commodity markets, and to propose a methodological framework for measuring these gaps. One possibility that is currently investigated but not developed further in this dissertation is to capture the market development gap as a residual of the total price gap and the estimated policy-induced price gap. Such information seems useful for policy makers as breaking down prices gaps permits to differentiate between explicit policy protection and excessive costs and rents benefiting particular agents in the value chain. To demonstrate the validity of the concept and its measurement, the proposed methodology would need to be applied to several commodities across countries and determine whether the estimation of the market development gap helps to better 
understand the factors driving the important disincentives affecting producers in developing and emerging economies even in cases where the Nominal Rate of Protection and/or the Producer Support Estimate (PSE) are close to zero suggesting no policy distortion.

Moreover, some limitations to the traditional policy measurement exercise need to be mentioned, particularly those resulting from partial equilibrium approaches. Results usually need to be interpreted with care as no single indicator is able to capture all policy effects. As was previously noted, production incentives can arise from many sources but in most studies they have been measured against changes in support provided to farmers through markets or indirect and direct monetary transfers.

On the expenditure side, it is obvious that the investment of public resources in rural areas, for example, for roads, irrigation, transport, storage, but also education and health care, provides direct and indirect incentives to producers. This type of support is what the WTO has been trying to measure and classify in its green, blue and amber boxes. The latter includes all domestic support measures considered to distort production and trade (with some exceptions) and is expressed in terms of a "Total Aggregate Measurement of Support" (Total AMS) which includes all supports for specified products together with supports that are not for specific products, in one single figure. Similarly, the OECD captures the overall support received by producers through its aggregate PSE indicator. While the PSE is only one of several indicators which measure assistance to producers, it is probably the most popular in policy as well as academic circles. The PSE mainly focuses on the measurement of the gross costs to consumers and taxpayers of the transfers to the agricultural sector. But, conscious of the PSE limitations, the OECD also publishes the Total Support Estimate (TSE) which adds to the PSE an estimate of the General Services provided to producers (GSSE) encompassing collective subsidies in kind to farmers such as agricultural research, extension, sanitary services, infrastructure, marketing promotion, etc.

Several other dimensions of potential policy effects are not captured in the PSE family of indicators. As we pointed out above when we discussed the market development gap, specific measurement problems such as benefits or costs to producers that might arise from informal transaction costs, externalities, market failures, any other behind-the-border policies and underinvestment in public goods, are not integrated in most analyses. In addition, existing methods and resulting indicators have failed to solve major problems or limitations resulting from some highly questionable assumptions in the African context, such as competitive markets, perfect information, and the generally high degree of substitutability between commodities. Africa is also characterised by extreme product heterogeneity compared with the situation in Asia or Latin America. This fact has also contributed to explain the different pattern of agricultural transformation relative to the trajectories of other regions of the world. In that sense, partial equilibrium-based indicators do not constitute dynamic measures of policy signals that would permit an adequate description and explanation of transformative processes in agriculture.

In SSA, monetary transfers in support of the agricultural sector arise from national budgets as well as international aid. Aid can take many forms including the provision of global budget support, financing of sector wide approaches or funding more specific programmes and projects. As such, aid flows add to the incentive structure of SSA economies. This point was not extensively developed in this dissertation but it appears important to discern whether resources are being allocated to priority areas as defined by governments, whether these transfers address investment needs, and whether they are consistent with the system of incentives that is in place. Regardless of whether they arise from national budgets or aid, 
effective monitoring and evaluation of public expenditures is vital for well-functioning and accountable governments as it allows assessments of the efficiency, effectiveness and equity of allocations of large amounts of government resources and for guiding future investment priorities in the agricultural sector, in particular. These are some of the main reasons why tracking of public expenditure and aid flows is seen as an important exercise for reviewing and analysing government policies.

Finally, we realize that the results discussed in this dissertation are too partial to provide a complete picture of the role of policies in support of production incentives and their effects on market distortions. There are many opportunities for future research to expand and deepen the topics investigated in this dissertation.

As there is general recognition of the need to rely on more than one indicator to adequately depict the extent and depth of policy support and derive meaningful and reliable conclusions, we find value in the idea of a systematic effort to estimate production incentives combining three main elements: (i) spending in support of the agricultural sector including both national expenditures and aid, (ii) price incentives or disincentives resulting from explicit policies, and (iii) estimating the price wedges due to the so called "market development gap". Systematic measurement and reporting of these three main dimensions would represent an ambitious and innovative attempt to measure the overall support or taxation from one nation to its farmers. As such, we encourage academic circles and institutions interested in this topic such as the OECD, IFPRI, World Bank and the FAO through its MAFAP programme to continue and expand their policy measurement and monitoring work.

As suggested above, we believe that empirical research could focus on better establishing the concept of the market development gap and the way to measure it. Attempts to measure it could also lead to interesting empirical analyses from which a new set of policy recommendations could emerge.

Moreover, most of the results presented in this dissertation focus on the effects of policy support and market distortions in output markets. It is acknowledged that to account for the full spectrum of policy distortions, there is a need to also incorporate policy effects on input markets. In that sense, computing effective rates of protection (ERP) for a growing number of countries in SSA appears to be the logical next step, for example in the context of the MAFAP programme assuming that data are readily available for both output and input markets.

In addition, we showed that trade, market and price policies are key to influence the speed and depth of the production response. However, the main linkages between the various policy instruments used by governments and their effects in support of accelerated agricultural transformation need to be better established and explained. It is proposed to also focus on the role of policies in shaping a favourable enabling environment for structural transformation of agriculture in SSA and especially small holders.

Considering that widespread food insecurity in SSA countries is in itself a market failure (Rocha, 2006), more work could focus on the linkages between trade policy and food security. Indeed, after the 2007-08 crisis, most governments in SSA as well as in the rest of the developing world demonstrated mistrust and reluctance to rely on international markets as a means of achieving food security of their population. In a number of cases, this has led to a renewed interest in policy measures that focus on food self-sufficiency at national or regional levels, as opposed to self-food reliance for which international trade plays a major role for food availability, access, and stability. In some cases, this shift is explained by the belief that some countries can actually be either structurally or temporarily vulnerable to trade for their food security. 
More research is needed to support this argument and identify those countries for which trade could be seen as a threat to food security and why. Moreover, such research should also investigate the types of policies that could underpin an effective role of markets and trade.

While chapter 5 of this dissertation indicates that farmers in SSA respond positively to price increase, as well as other factors including policy incentives and efficient marketing margins, the results do not provide information on the supply response to declining prices. This makes it difficult to test hypotheses of supply response asymmetries. In future research, it would be useful to clarify this point through further empirical analyses. 


\section{References}

African Union. (2003). Maputo Declaration on Agriculture and Food Security. Assembly of the African Union the Second Ordinary Session

African Union. (2014). Malabo Declaration on Accelerated Agricultural Growth And Transformation for Shared Prosperity And Improved Livelihoods. Declarations of the Assembly of the Union TwentyThird Ordinary Session

Akiyama, T., Baffes, J., Larson, D. F., and Varangis, P. (2003). Commodity Market Reform in Africa: Some Recent Experience, World Bank Policy Research Working Paper 2995.

Anderson, K. and Kurzweil, M. (2008). Measuring distortions to agricultural incentives, revisited. Policy Research Working Paper 4612, The World Bank Development Research Group Trade Team, Washington.

Anderson, K. (2009). Distortions to Agricultural Incentives- A Global Perspective, 1955-2007., Washington DC: Palgrave Macmillan and the World Bank.

Anderson, K. and Masters, W. (2009). Distortions to Agricultural Incentives in Africa. Washington, DC, World Bank.

Anderson, K. and Nelgen, S. (2012). Updated national and global estimates of distortions to agricultural incentives, 1955 to2010. Wolrd bank. Washington DC.

Angelucci, F., Balié, J., Gourichon, H., Mas Aparisi, A., Witwer, M. (2013). Monitoring and Analysing Food and Agricultural Policies in Africa. MAFAP Synthesis Report 2013. MAFAP Synthesis Report Series, FAO, Rome, Italy.

Asenso-Okyere, K. and Jemaneh, S. (2012). Increasing agricultural productivity and enhancing food security in Africa. Synopsis of an international conference. IFPRI, Washington, DC

Balié, J., and Maetz, M. (2011). Policy analysis in Africa: A review of experiences and methods. MAFAP series. FAO, Rome, Italy.

Baffes, J and Gardner, B. (2003). The transmission of world commodity prices to domestic markets under policy reforms in developing countries. Journal of Economic Policy Reform, Taylor \& Francis Journals, vol. 6(3), pages 159-180.

Barrett, C.B. (2008.) Smallholder Market Participation: Concepts and Evidence from Eastern and Southern Africa. Food Policy 33:299-317.

Bates, R.H. (1981). Markets and States in Tropical Africa: The Political Basis of Agricultural Policies. Berkeley: University of California Press.

Bates, R. H. (1983). Essays on the Political Economy of Rural Africa. African Studies Series No. 38.

Benson, T. (2004). Africa's Food and Nutrition Security Situation-Where Are We and How Did We Get Here? Background paper prepared for the 2020 Africa Conference "Assuring Food and Nutrition Security in Africa by 2020: Prioritizing Actions, Strengthening Actors, and Facilitating Partnerships", Kampala, Uganda, April 1-3, 2004.

Byerlee, D., Garcia A., Giertz A., and Palmade V. (2013). Growing Africa - Unlocking the potential of agribusiness. Washington, DC: The World Bank. 
Brooks, J. (2010). Agricultural Policy Choices in Developing Countries: A synthesis. Paper presented to the Working Party on Agricultural Policy and Markets, 15-17 November 2010, TAD/CA/APM/WP(2010)41. OECD, Paris

Chamberlin, J and Jayne T. S. (2011). Unpacking the Meaning of "Market Access", Staff Papers 110014, Michigan State University, Department of Agricultural, Food, and Resource Economics.

Clover, J. (2003). Food Security in Sub Saharan Africa. African Security Review, Vol 5

Devereux, S. (2009). Social Protection for Agricultural Growth in Africa. Working Paper. FAC. SP06.

Demeke, M., Pangrazio, G., and Maetz, M. (2009). Country response to the food security crisis: nature and preliminary implications of the policies pursued. FAO, Rome, Italy.

Demeke, M., Spinelli, A., Croce, S., Pernechele, V., Stefanelli, E., Jafari, A., Pangrazio, G., Carasco, G., Lanos, B. and Roux, C. (2014). Food and agricultural policy decisions: trends, emerging issues, and policy alignments since the $2007 / 08$ food security crisis. FAO, Rome, Italy.

Di Marcantonio, F; Morales Opazo, C. and Barreiro-Hurle, J. (2014). Determinants of food production in Sub Saharan Africa: The impact of policy, market access and governance. Paper for the 2014 EAAE Congress in Ljubljana, Slovenia, 26-29 August.

Dorward, A., Kydd, J., Poulton, C. (2007). Price intervention in Sub-Saharan African Agriculture. Can an institutionalist view alter our conception of the costs and benefits? In Koning, N. and PinstrupAndersen, P (Eds). Agricultural Trade Liberalization and the least Developed Countries, 51-66. Springer.

FAO. (2012). Investing in agriculture for a better future. The State of Food and Agriculture. FAO, Rome, Italy.

FAO. (2014). MAFAP database. http://www.fao.org/mafap/database/en/ ).

FAO. (2015). MAFAP Methodological paper: Volume I. Analysis of price incentives. MAFAP Technical Notes Series, FAO, Rome, Italy.

FAO, IFAD and WFP. (2015). The State of Food Insecurity in the World 2015. Meeting the 2015 international hunger targets: taking stock of uneven progress. FAO, Rome, Italy.

Friis Hansen, E. (2000). Agricultural policy in Africa after adjustment. CDR Policy Paper. Centre for Development Research. September 2000

Getnet, K., Verbeke, W., and Viaene, J. (2005). Modelling spatial price transmission in the grain markets of Ethiopia with an application of ARDL approach to white teff. Agricultural Economics, 33, 491502.

Hall, R. and Jones, C. (1997). Levels of Economic Activity across Countries, American Economic Review. 87: 173-177.

Hall, R., and Jones, C. 1999. Why Do Some Countries Produce So More Output Per Worker Than Others? Quarterly Journal of Economics 114:83-116.

Hazell, P., Poulton, C., Wiggins, S., and Dorward, A. (2010). The Future of Small Farms: Trajectories and Policy Priorities. World Development, 38(10), 1349-1361.

Hollinger, F. and Staatz, J. M. (Eds.). (2015). Agricultural growth in West Africa. Market and Policy drivers. Food and Agriculture Organization of the United Nations and African Development Bank. FAO, Rome,

Howell, J. (2005). Farm subsidies: A problem for Africa too. London: Overseas Development Institute.

Jacoby, H. G. (2000). Access to Markets and the Benefits of Rural Roads. The Economic Journal, 110(465), 713-737. 
Jacoby, H. G., and Minten, B. (2009). On measuring the benefits of lower transport costs. Journal of Development Economics, 89(1), 28-38.

de Janvry, A and Sadoulet E. (2000). Rural poverty in Latin America: Determinants and exit paths. Food Policy, Elsevier, vol. 25(4), pages 389-409, August.

Knack, S and Keefer P. (1995). Institutions and economic performance: cross-country tests using alternative institutional measures. Economics and Politics 7, 207- 227.

Keefer, P and Knack S. (1997). Why don't poor countries catch up? A cross-national test of an institutional explanation. Economic Inquiry 35, 590-602.

Kherallah, M., Delgado, C., Gabre-Madhin, E., Minot, N., Johnson, M. (2000). The road half travelled: Agricultural market reform in Sub-Saharan Africa. International Food Policy Research Institute (IFPRI), Washington, USA.

Kherallah, M., Delgado, C.; Gabre-Madhin, N., Minot, N.; Johnson, M. (2002). Reforming Agricultural Markets in Africa. Food Policy Statements 38, International Food Policy Research Institute (IFPRI), Washington, USA.

Krueger, A., Schiff, M., and Valdes, A. I. (1988). "Agricultural incentives in developing countries: measuring the effect of sectoral and economic wide policies." The World Bank Economic Review, Vol. 2, No 3.

Krueger, A. , Schiff, M., and Valdes, A. (Eds). (1991). The Political Economy of Agricultural Pricing Policy. Volume 3: Africa and the Mediterranean. Washington, DC, World Bank.

Maetz, M., Aguirre, M., Kim, S., Matinroshan, Y., Pangrazio, G., and Pernechele, V. (2001). Food and agricultural policy trends after the 2008 food security crisis - renewed attention to agricultural development. FAO, Rome, Italy.

Mason, N. M., Jayne, T.S., and van de Walle, N. (2013). Fertilizer Subsidies and Voting Patterns: Political Economy Dimensions of Input Subsidy Programs. 2013 Annual Meeting, August 4-6, 2013, Washington, D.C. 149580, Agricultural and Applied Economics Association.

Mellor, J. W.;Delgado, C. L.;Blackie, M. J. (1987). Accelerating food production in Sub-Saharan Africa. International Food Policy Research Institute (IFPRI). Washington, D.C., USA. pp. 434 pp.

Mérel, P. R., Sexton, R. J., \& Suzuki, A. (2009). Optimal Investment in Transportation Infrastructure When Middlemen Have Market Power: A Developing-Country Analysis. American Journal of Agricultural Economics, 91(2), 462-476.

Meyer, J., and von Cramon-Taubadel, S. (2004). Asymmetric Price Transmission: a Survey. Journal of Agricultural Economics 55 (3): 581-611.

New Partnership for Africa's Development. (2014). Agriculture in Africa: Transformation and Outlook. Online available at: http://www.nepad.org/system/files/Agriculture\%20in\%20Africa.pdf

Nin-Pratt, A., Yu, B. (2009). An Updated Look at the Recovery of Agricultural Productivity in Sub-Saharan Africa. Contributed Paper prepared for presentation at the International Association of Agricultural Economists Conference, Beijing, China, August 16-22, 2009

Nin-Pratt, A., Yu, B. (2011). Agricultural Productivity and Policies in Sub-Saharan Africa. IFPRI Discussion Paper 01150. December 2011, Washington DC.

Omamo, S. W. (1998). Transport Costs and Smallholder Cropping Choices: An Application to Siaya District, Kenya. American Journal of Agricultural Economics, 80(1), 116-123.

Onal, A. (2012). An empirical analysis of supply response for selected export crops in Sub-Saharan Africa. African Agricultural Reforms, 89. 
Poulton, C., Kydd, J. and Dorward, A. (2006). Overcoming market constraints on pro-poor agricultural growth in sub-Saharan Africa. Development Policy Review, 24(3), 243-277.

Quiroz, J. and Valdés A. (1993). Agricultural Incentives and International Competitiveness in four African Countries: Governments Interventions and exogenous Shocks. In Agricultural Policy Reforms and Regional Market Integration in Malawi, Zambia, and Zimbabwe, edited by A. Valdés and K. MuirLeresche, Washington DC: IFPRI.

Ricker-Gilbert, J, Mason N. M., Darko F., Jayne T. S., Tembo S. (2013). What are the Effects of Input Subsidies on Maize Prices? Evidence from Malawi and Zambia. Food Security Collaborative Working Papers 154938. Michigan State University, Department of Agricultural, Food, and Resource Economics.

Shepherd, A. (2007). Approaches to linking producers to markets: a review of experiences to date. Rome: Food and Agriculture Organization of the United Nations.

Shimeles A., Zerfu Gurara D., and Birhanu Tessema D. (2015). Market Distortions and Political Rent: The case of Fertilizer Price Divergence in Africa. IZA Discussion Paper No. 8998. Discussion Paper Series Institute for the Study of Labor

Sitko, N., and Jayne, T. (2012). The Rising Class of Emergent Farmers: An Effective Model for Achieving Agricultural Growth and Poverty Reduction in Africa? Food Security Collaborative Working Papers 140907. Michigan State University, Department of Agricultural, Food, and Resource Economics.

Townsend, R. (1999). Agricultural Incentives in Sub-Saharan Africa. World Bank Technical Paper 444. Washington Dc.

Wolf, C. Jr. (1979). A theory of nonmarket failure: framework for implementation analysis. Journal of Law and Economic 22 (1): 107-139.

World Bank. (2007). World Development Report 2008: Agriculture for Development. Washington, DC: The World Bank. 